University of Louisville

ThinkIR: The University of Louisville's Institutional Repository

Electronic Theses and Dissertations

1941

\title{
The Municipal Bureau of Social Service of Louisville, Kentucky : rejected cases, November and December, 1940.
}

\author{
Alice Roberts Farmer \\ University of Louisville
}

Follow this and additional works at: https://ir.library.louisville.edu/etd

Part of the Social Work Commons

\section{Recommended Citation}

Farmer, Alice Roberts, "The Municipal Bureau of Social Service of Louisville, Kentucky : rejected cases, November and December, 1940." (1941). Electronic Theses and Dissertations. Paper 1772.

https://doi.org/10.18297/etd/1772

This Master's Thesis is brought to you for free and open access by ThinkIR: The University of Louisville's Institutional Repository. It has been accepted for inclusion in Electronic Theses and Dissertations by an authorized administrator of ThinkIR: The University of Louisville's Institutional Repository. This title appears here courtesy of the author, who has retained all other copyrights. For more information, please contact thinkir@louisville.edu. 


\title{
UNTVERSITY OF LOUISVIIILE
}

THE MUNICIPAL BURFAU OF SOCIAL SERVICE OF LOUISVILLE, KENTUCKY: REJECTED CASES, NOVEMBER AND DECEMBER, 1940

\author{
A Dissertation \\ Submitted to The Faculty \\ Of The Graduate School of The University of Louisville \\ In Partial Fulfillment of The \\ Requirements for The Degree \\ of Master of Science in Social Administration
}

Division of Social Administration

By

Alice Roberts Farmer

1941 
NAME OF STUDENT: Alice Roberts Farmer

TITLE OF THESIS: The Municipal Bureau of Social Service of

Louisville, Kentucky; Rejected Ceses, Norember and December, 1940.

APPROVED BY READING COMMITTEE COMPOSED OF THE FOLLOWING MEAMBERS:

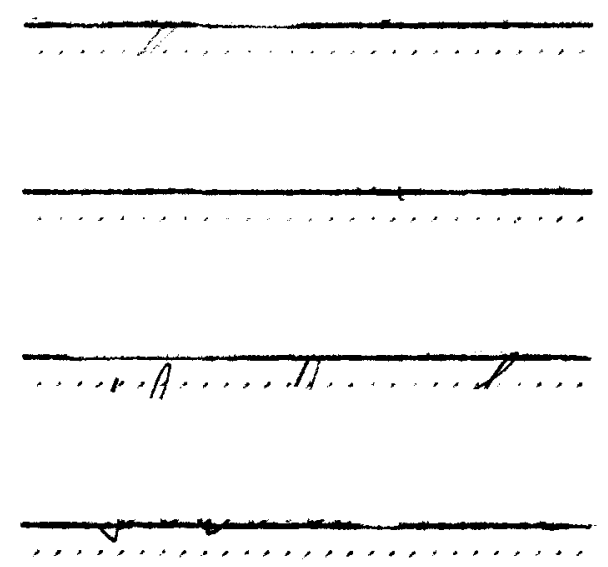

NAME OF DIRECTOR: Dr. Margaret $\mathrm{K}$. Strong

Date: May 30, 1941 


\section{ACKNOWLEDGMENT}

Without the cooperation and assistance of the officials of the Department of Public Welfare and of the staff of the Munioipal Bureau of Sooial Service, this study would not hare been possible. I am especially indebted to Miss Gertmude Richman. Superintendent of the Municipal Bureau of Social Service, and to Miss Louise Diecks, Supervisor of The Intake Department, whose advice and information were invaluable.

I gratefully acknowledge my indebtedness to $\mathrm{Dr}$. Margaret K. Strong, who supervised me in the research project which is the basis of this dissertation. 
ABBREVIATIONS

C.C.C., Civilian Conserration Corps.

K.E.R.A., Kentucky Emergenoy Relief Administration.

M.B.S.S., Municipal Bureau of Social Service.

M.R.B., Municipal Relief Bureau.

N.Y.A., National Youth Administration.

J.R.B., Unemployment Relief Bureau.

W.P.A., Works Progress Adrinistration, also

Works Projects Administration. 
THE MUNICIPAL BUREAD OF SOCIAL SERVICE OF LOUISVILLE, KENTUCKY: REJECTED CASES

NUVEMBER AND DECEMBER, 1940 
I. THE EISTOFY OF THE MUNICIPAL BUREAU OF SOCIAL SERVICE

A. Emergency Relief, November, 1930 - August, 1933. 7

B. Shared Responsibility, September, 1933 - August, 1936. 15

C. Local Responsibility, September, 1936 - August, 1940. 26

II. THE PEIIEF PROBLEI IN LOUISVILLE 38

A. Felief Appropriations and Average Grants. 39

B. Some Administrative Froblems. 50

C. The Need.

III. REJECTED CASTS, NOVEMBER AIDD DECENBER, 194,0

A. Cenersi Description. 68

B. Rejection Reasons. 72

C. Family reed. 83

D. Family Resources 96

E. Family Adjustment. 113

COMCIUSION

BIBLIOGEAFHY $\quad 149$

AFPEIDIX $\quad 152$ 
INTRODUCTION 
INTRODUCTION

The subject for this study was suggeeted by the Superintendent of the Municipal Bureau of Social Service, when she learned of our interest in the relief situation in Louisville. Because of interest in and desire to improve standards and services, the 1hunicipal Bureau of Social Service cooperated fully in the investigation. All records and files were made available. Members of the staff gave freely of their time and information.

The program of general relief administered by the agency represents the responsibility which Louisville itself has taken for dependent femilies. A study of the persons refused relief seomed one method of gaining insight into public policy. The months, Norember and Decenber, 1940, were chosen for study, because they were current months and, therefore, more easily available. They also seomed to be fairly typical months; that is, there is usually more need for relief later in the winter and less need during the summer and early autumn. All of the agency case records on families refused direct relief during Notember and December were read. Although the current rejection was the subject of primary interest, material contained in old records is also significant. In the Appendix is a copy of Form $A$, which was used to record the desired information. In order to gain insight into the adjustments made by families to their rejeotion and into their situation some months later, home visits were made, in March, 1941, to ten per cent 
of the rejected cases. As a measure of the extent of the financial need existing in the homes, minimum standard budgets were computed for each family. The figures for these budgets were based on the standards set up by the Works Projects Administration in Kentucky, because these stendards are widely used throughout the State and are acoepted as valid by the Munjeipal Bureau of Social Service. Knowledge of the history and general policy was gained from annual reports of the agency and of the Department of Public Welfare. Unpublished data collected in the files of these two organizations were utilized. Interviews with the staff of the Bureau and of other social agencies served to fill in gaps in our understanding. Newspaper publicity gave insight into problems and controversies. Other studies and investigations of the relief situation were consulted.

The public assistance program in Louisvilie has been severely handicapped by lack of commuity understanding of the problem. For this reason there has been lack of adequate financial support for a developing program. The question, how can money be secured, seems to be of primery importance.

The investigation was undertaken with several questions in mind. What is the history of the Municipal Bureau of Social Service? With what administrative problems has it been confronted? What has been its function in the community? Is there a continuing relief problem in the City of Louisville? If so, what is its nature and extent? In particular, how many and what kind of cases are being refused assistance? What are the other resources upon which these 
families have to depend? How adequately are they able to manage? Our effort is to gain some insight into the local relief problem while realizing that the limitations of our study give us only a partial picture of the whole situation. For purposes of social planning the need for other and more exhaustive pieces of social research is acknowledged. 
I. THE HISTORY OF THE MUNICIPAL BUREAU OF SOCIAL SERVICE 
I. THE HISTORY OF THE MUNICIPAL BUREAU OF SOCIAL SEEVICE

The history of the Nunicipal Bureau of Social Service of Louisville falls, chronologically, into three periods. The first, from November, 1930 through August, 1933, was the period of emergency aid for winter months only. During the second period, from September, 1933 through August, 1936, there were funds from the federal government. Since August, 1936, the city has had to carry the entire financial responsibility.

Prior to 1929 there was very little relief given in Louisville from public funds. The Board of Pablic Safety had complete control of the charitable, penal and reformatory institutions administered by the city. Assistance to persons in need was considered as the function of private agencies. The Fiscal Court of Jefferson County granted small sums for general relief. The County Court administered Pauper Idiot pensions of seventy-five dollars a year, financed fifty per cont by the state. A Mother's Aid program financed by the county had been in operation since 1928. There was distribution of coal by the city during winter months. A modern public welfare program in Louisville was made possible when an Act was passed in 1926 by the General Assembly of the State, authorizing the setting up of such a department in the city. This law reads:

1. Lewis, Burdett and Kutak, Mrs. Robert, A Preliminary Plan for Securing A Better Comordination of the Governmental Forces of Louisville and Jefferson County, Mimeographed, 1936, p. 17. . 
"The Department of Public Welfare of cities of the first class when establishod as provided herein shall bo under the supervision and direction of a director to be designated director of welfare, and shall, except as otherwise provided by law, have exclusive control, ..... of all matters relating to the provision for and the supervision of the care of adult and juvenile delinquents, dependents, and persons mentally deficient; the investigation of conditions that develop dependency, delinquency and mental deficiency; the education of the public regarding such conditions and the adoption of remedial measures; the provision for and supervision of public amusements and the promotion of opportunitios for healthful recreation in playgrounds and community centers; the supervision of public baths, comfort stations and cemeteries, the Detention Home, the Home for The Aged and Infirm, the City Work House; and may prescribe rules and regulations for the government and discipline of the inmates of the eity's charitable and penal institutions ......; and the supervision and the maintenance at the University of Louisville of classes in social welfare in order to provide trained workers for service in said department; and such other matters as may by ordinance be placed under the control of the said department not in conflict with any Act of the General Assembly. The director of welfare shall have the power to organize the seid department for administrative purposes into such divisions as may be necessary for the proper conduct of the business of said department, and to appoint heads or chiefs of such divisions who, under the supervision of said director, shall have the direction of such divisions." 2 .

An analysis of this law shows it to be modern in its point of view and progressive in its spirit. We find recreation recognized as a public function. The depertment is authorized to conduct investigations and to inform and educate the public. The need for professional training of personnel is recognized. There is flexibility and centralization of control making possible the building of a staff of competent persons.

A. Emergency Relief, November, 1930 - August, 1933.

With the increasing load at the beginning of the depression,

2. Carroll's Kentucky Statutes, 1936 Revision, Section 2862. 
it became apparent that the private agencies could not hope to cope with the situation. The city and county began subsidizing the Family Service Organization, a private family case work agency. In 1929, together, they contributed $\$ 27,500$. The city had used this subsidy syrstem before and had boen for years refunding money spent for the transportation of non-residents, but 1929 marked the beginning of regular contributions. These were, in general, made through the Cormunity Chest.

\section{Table I}

\section{3}

Income of Family Service Organization from Tex Funds.

$\begin{array}{llll}\text { Year } & \text { Amount } & \text { Year } & \text { Amount } \\ & & & \\ 1929 & \$ 27,500 & 1934 & \$ 99,626 \\ 1930 & 15,500 & 1935 & 105,868 \\ 1931 & 108,019 & 1936 & 73,000 \\ 1932 & 127,000 & 1937 & 83,000(\mathrm{a}) \\ 1933 & 155,357 & 1938 & 68,000(\mathrm{a})\end{array}$

(a) Amount represents the city's contribution to the Community Chest. Not all of this money went to the Family Service Organization for direct relief.

The private agency undertook to care for those families in which there were no employable members. It gave some relief as supplementation of the work relief wages of the Unemployment Relief Bureau. Gradually the city assumed more responsibility and there was a transfer of cases from the Family Service Organization. In Apri1, 1938, this process was complete. Since that time the public agency has accepted responsibility for the major relief load

3. Ellis, Bernice, A History of The Family Service Organization, prepared in partial fulfillment of the requirements for the degree of Haster of Arts, University of Chicago, School of Social Service Administration, 194l, Chapter VI, Table XVII. 
of the city. The Family Service Organization has had only limited funds for financial assistance. This it gives to families on a strictly individual besis and only as a service related to other social case work services.

The Department of Public Welfare of the City of Louisville began functioning in January, 1930. By a special ordinance of the Board of Aldermen, the Unemployment Relief Bureau was opened on November 11, 1930, as a branch of the Department. It was established to give work relief to unemployed heads of families. Instead of accepting men with one or more dependents, it was decided to accept only men who had dependents under sixteen years of age. This policy did not include adult families or men living apart from their wives and children.

The registration for work relief on Ootober 29 and October 30, 1930, showed 11,725 unemployed anxious to work. Late registram tions, lasting through March 31, 1931, brought the total up to 13,911. Of this number 3,282 represented themselves as having dependents under sixteen. Of these, 1,641 were rejected for various 4

reasons. Work relief was given on the basis of a twenty-four hour week paid at the rate of thirty cents an hour plus car checks. Made work was provided by charitable institutions and in the city departments. The total amount appropriated by the city was $\$ 111,631$. Of this, $\$ 25,485$ was spent for work done in charitable institutions. Throughout the winter, the number of men employed changed constantly.

4. City of Louisville, Unemployment Relief Bureau, Annual Report November 11, 1930 - July 15, 1931, pp. 1-2. 
The first week, only 49 wore employed. The number increased gradually to a peak of 1,268. An unduplicated total of 1,617 persons were actually given work at one time or another during the winter. In addition, the Unemployment Relief Bureau had the responsibility for distributing "city coal." This was done on the basis of refusing applicants whose income exceeded 40.00 a month. A total of 6.855 families was given 11,604 half tons of coal. There were 1,567 families who applied for coal but were refused it.

Soon after its establishment, the agency took over responsibility for investigation of applications for admittance to the Home for The Aged and Infirm. Because of the pensions administered by the county, only the aged needing institutional care were admitted to the Home.

Beginning in December, 1930, an effort was made to provide for the needs of transients in cooperation with the Travellers' Aid Society. Several hundred transients were interviewed and a few were returned to their places of legal residence. At this time, the direct relief burden was being carried by the Family Service Organization, through the subsidy mentioned previously. This agency assisted from 1,800 to 2,200 families per month during that winter.

Some indication of the attitude toward the program can be obtained from a quotation from the letter transmitting the Annual Report for the year 1931-1932. "As you know, the economic depression has brought to many homes certain disastrous results that are irreparable. It has been the job of this Bureau to alleviate the suffering of the

5. Ibid., p. 2 .

6. Strong, Margaret K., Public Welfare Administration in Louisville, Kentucky, Typewritten, 1935, pp. 23-24. 
poor with as little cost to the city as posible."

The work relief program of the winter 1930-1931 was resumed on November 5, 1931, after $\$ 170,000$ was appropriated by the city for that purpose. The general plan of giving work only to heads of families with dependents under sixteen years of age was continued. Adult families were also eligible in situations in which work relief "would prevent the commitment of a member of the family to a city institution." Again, men who were separated from their families were not eligible. Work was confined to that furnished in city departments and by public and private institutions. The men were permitted to work from twentyfour to twenty-seven hours a week at the rate of thirty cents an hour plus carfare, earning approximately from $\$ 7.20$ to $\$ 8.10$ a week. In-. sight into the restrictive intake policy may be obtained from the statement that work was not given "where there was the slightest possibility that the client could manage without it." ${ }^{8}$ Preference was not given according to the number of children dependent on the wage earner, because it was felt that "during this time of economic strife was no time to put a premium on large femilies....." From June, 1931 through March, 1932, a total of 7.075 persons registered as being in need of work. During that winter only 1,905 were actually given any work. of these, $31 \%$ had been employed by the U.R.B. the previous winter. In an attempt to find employment for those men whom it could not employ itself, in March, 1932, the U.R.B. cooperated with the American Legion in a plan to place men after the employer had made the request at the Legion office. There were 253 requests for

7. City of Louisville, Unemployment Felief Bureau, Annual Report $1931-1932, \mathrm{p} .1$.

8. Ibid., p. 2 .

9. Ibid., p. 2 . 
employment and 150 men found jobs, but the majority of these lasted only a few hours. The plan was a great disappointment. Its main trouble lay in the fact that there was very little attempt made to 10

fit the men to the jobs.

During this year, 1931-1932, the Unemployment Relief Bureau accepted responsibility for all single homeless persons who had been in Louisville over two weeks. All who had been in the city less than two weoks were referred to Travellers' Aid. The Unemployment Relief Bureau had no relief funds for these non-residents, but gave service in returning them to their places of settlement, placing them with relatives, etc. Men could obtain lodging if they sawed wood for an hour. They seldom got more than one night's lodging. The police brought beggars to the U.R.B. After an investigation was made, the beggar was "planned for socially." When the beggar "refused to cooperate", the Bureau recommended in11 oarceration.

Beginning in April, 1932, the Unemployment Relief Bureau began a more intelligent program of finding private employment for those in need. This program was confined to domestics. The workers were given physical examinations, the employers were required to give references and an attempt was made to fit the person to the job. This program was more successful, and by August, 1932 a total of seventy-seven persons had obtained permanent jobs. 12 The Bureau continued to distribute city coal. It gave a total of 8,452 half tons to 3,530 families. It also delivered 495 cords of wood, which

10. Ioid., pp. 11 and 13.

11. Ibid., pp. 17-18.

12. Ibid.. p. 20 . 
had been sawed by transients and fjlled 3,344 requests for coal 13

from various public and private social agencies.

For the fiscal year ending in July, 1933, there was no report made by the agency. There were very few records kept and most of the statistics do not correspond with the fiscal year. The number of men employed on work relief projects for the calendar year 1933 varied from 3,988 in March to 1,638 in July.

\section{Table II}

Number of Fersons Employed on Work Relief Projects, by Months for The Year, 1933. 14

$\begin{array}{lclc}\text { Month } & \begin{array}{c}\text { Number } \\ \text { Employed }\end{array} & \text { Month } & \begin{array}{c}\text { Number } \\ \text { Employed }\end{array} \\ \text { January } & 2,690 & \text { July } & 1,638 \\ \text { February } & 3,368 & \text { August } & 1,766 \\ \text { March } & 3,988 & \text { September } & 2,096 \\ \text { April } & 3,972 & \text { October } & 2,398 \\ \text { May } & 3,307 & \text { November } & 3,006 \\ \text { June } & 2,408 & \text { December } & 2,889\end{array}$

A total of 5,275 unduplicated families received work relief for the fiscal year ended September 30, 1933. For this year, the city appropriated $\$ 370,000$ for work relief. From Cctober 1, 1932 through August, $1933, \$ 365,504$ was distributed in cash and $\$ 355,401$ 15

in scrip. During September, over $\$ 1,000$ in cash alone was dis16

tributed. Although exact figures are not available, $\$ 750,000$ would seem a conservative estimate of the amount expended that year. Looking back on this first period from November, 1930

13. Ibid., pp. 25-26.

14. City of Louisville, Municipal Bureau of Social Service, Memorandum in office files.

15. Hall, M.D., Comptroller and Inspector, Letter to Mayor Harrison dated September 6, 1933.

16. Hall, M. D., Comptroller and Inspector, Letter to Mayor Harrison dated October 6, 1933. 
through August, 1933, we find that the giving of relief to ablebodied unemployed was considered strictly as an emergency measure. It is interesting to note that assistance was given only to this group. Other classes of dependents were left to the care of the county, which at that time was giving pensions to the aged, blind and "pauper idiots." An insignificant amount of general relief was administered by the city. The prinoipal form of aid was made work or "work for relief." The philosophy of this era is demonstrated by the fact that transients were given a work test. During the summer months, even the meager, inadequate work relief was discontinued and the unemployed asked to manage as best they could. Although it is easy to recognize the injustice and short-sightedness of this policy, we realize that the "business of relief" was a new one to the citizenry. They did not realize the extent of the problem and were totally unprepared to meet it. The unemployable cases and, during the sumer, the employable persons were given help by the Family Service Organization through a public subsidy. The evils and dangers of this system were fully recognized by the private agency, which accepted the responsibility principally because it had to. The city administration thought that the need for relief was temporary and would cease with improved business conditions. From that point of view there was logic in utilizing existing community resources rather than setting up a large, new agency. The Family Service Organization at this time was one of the major forces in the community working for the setting up of a more adequate public agency 
able to administer relief itself.

B. Shared Responsibility, September, 1933 - August, 1936.

By this time there were evidences of the realization that the Bureau had a definite permanent function and should not retain the policy of merely giving emergency relief to the unemployed. Its name was changed to the Municipal Relief Bureau. Since October, 1932, it has operated on a year round basis instead of discontinuing work rellef in the sumer as it had done previously. When Louisville was granted federal relief funds in 1933, the M.R.B. was given the responsibility for administering them. Under this program it impossible, because of federal regulation, for work projects to be undertaken on the property of private agencies. Therefore, those projects were discontinued.

In the early winter of 1933, the number of applications increased tremendously. General reorganization became necessary. On January 1, 1934, the Municipal Relief Bureau was divided into two distinct departments, the Unemployment Division and the City Division. The City Division was administered entirely, both as to personnel and relief, with funds appropriated by the city. It was organized with the idea of its becoming the permanent social service division of the Department of Publio Welfare. Its duties and responsibilities were the care and supervision of the dependent aged; incapacitated, permanently handicapped or maladjusted adult groups; and the single, homeless, resident individuals who could not fit into the work program. In the Unemployment Division the major part 
of the cost was borne by the federal goverment under the Federal Emergency Relief Administration. This division was responsible for all families and individuals who had unemployment as the major cause of their dependenoy. Until work relief could be provided, some direct relief was given according to need.

$$
17
$$

\section{Table III}

Expenditures of The Municipal Relief Bureau for The Fisoal Year 1933-1934. $18 \ldots \ldots$.

$\begin{array}{lccc} & & & \text { Local Public } \\ & \text { K.E.R.A. Funds } & \text { Funds } & \text { Total } \\ \text { All Expenditures } & \$ 451,360 & \$ 354,904 & \$ 806,264 \\ & & & \\ \text { Relief } & 372,916 & 320,825 & 693,742 \\ \text { Expenditures } & 237,803 & 21,4,023 & 481,826 \\ \text { Work Relief } & 114,125 & 76,803 & 190,928 \\ \text { Direot Relief } & 20,989 & & \\ \text { Other Relief } & 20,989 & & \end{array}$

Table III shows the relative amount of money spent by the city and the federal government. By it we see that the latter spent nearly one-third more than did the city. The table does not include the cost of administration for the distribution of surplus commodities or the value of the commodities distributed. The Municipal Relief Bureau began acting as a clearing house for these comodities in November, 1933. It distributed them not only to persons on relief at the M.R.B. but also to those being aided by several private

17. City of Louisville, Department of Fublic Welfare, Annual Report 18. for The Fiscal Year Ended August 31, 1934, pp. 18-19. 
agencies in the city.

In July, 1934, the State Homeless Department was set up, financed entirely by a separate appropriation from the Kentucky Emergency Relief Administration. (Funds came from the foderal government.) It took over from the Unemployment Division the responsibility for out of town inquiries. It investigated persons who were residents of Kentucky but not of Louisville and cared for them pending their return to their legel residence.

It was the City Division and the program of general relief which remained in existence in the following years, though work relief financed by federal funds continued almost until the advent of the W.P.A. When the W.F.A. took over this responsibility, all administration, except the taking of applications, was removed from the Bureau.

In February, 1934, Jefferson County discontinued all pensions for the blind and for the aged. This meant that the city Division of the Municipal Felief Bureau became responsible for 19 these groups. Early in 1934 a study revealed that the county appropriation for Mothers: Aid was almost depleted. The potential Nothers' Aid families were being cared for by the Family Service Organization. It was necessary for the M.R.B. to take over these cases and to assume responsibility for future applicants until adequate appropriations could be made by the Fiscal court. For the fiscal year ended August 31, 1935, there was an

19. City of Louisville, Department of Fublic Welfare, Annual Report for The Fiscal Year Ended August 3I, 1935, p. 23 .

20. Ibid.. pp. 19-20. 
City Division, Arerage Direct Relief Grants Per Case, By Months from September, 1934. Through August, 1940.

Month

Fiscal Year

$1934-135 \quad 1935-136 \quad 1936-137 \quad 1937-138 \quad 1938-139 \quad 1939-140$

\begin{tabular}{|c|c|c|c|c|c|c|}
\hline September & $\$ 22.28$ & $\$ 14.66$ & $\$ 14.71$ & $\$ 17 \cdot 41$ & $\$ 18.71$ & $\$ 14.84$ \\
\hline October & $15 \cdot 41$ & 14.68 & 17.39 & 20.77 & 19.30 & 16.00 \\
\hline November & 13.26 & 15.18 & $17 \cdot 42$ & (a) & 20.46 & 18.97 \\
\hline December & 14.06 & 14.57 & 19.15 & 20.43 & 22.17 & 21.05 \\
\hline January & 13.03 & 16.18 & 16.12 & 17.97 & 21.95 & 13.67 \\
\hline February & 10.14 & 17.81 & 9.62 & (a) & 21.90 & 16.01 \\
\hline March & 14.95 & $17 \cdot 28$ & 17.16 & (a) & $21 \cdot 34$ & 20.87 \\
\hline April & 14.14 & 16.33 & 19.03 & (a) & 20.78 & 18.80 \\
\hline May & (a) & $15 \cdot 54$ & $17 \cdot 52$ & $17 \cdot 74$ & $17 \cdot 46$ & 18.02 \\
\hline June & (a) & 16.06 & 17.42 & (a) & 16.21 & 14.63 \\
\hline July & (a) & 16.62 & $17 \cdot 21$ & (a) & 15.76 & 14.07 \\
\hline August & (a) & 16.25 & $19 \cdot 32$ & (a) & 15.23 & $15 \cdot 41$ \\
\hline $\begin{array}{l}\text { Average for } \\
\text { the year }\end{array}$ & $\$ 14 \cdot 93$ & & & & $\$ 19.19$ & $\$ 16.86$ \\
\hline
\end{tabular}

(a) Figures for these months are not available.

Source: City of Louisville, Department of Public Welfare, Annual Reports; Municipal Bureau of Social Service, Monthly Statistical Reports. 
average monthly direct relief total case load in the City Division of 705 . The average relief grant per case was $\$ 14.93$ per month. There was an average monthly load of 3,775 K.E.R.A. cases with average relief grants of $\$ 21.30$. The City Division spent a total of $\$ 126,294$ while there were $\$ 1,018,652$ of K.E.R.A. funds expended. Table IV gives the average relief grant of the City Division by months. We see the wide fluctuations from month to month, ranging from $\$ 22.28$ in September, 1934 to $\$ 10.14$ in February, 1935. Table V and Graph I show the fluctuation in arerage monthly case load. Throughout the year, there was a steady rise. The load more than doubled, being only 418 in September, 1934 and over 900 in August, 1935. Table VI gives an analysis of this case load according to the category into which the family or individual fitted. By it we see that over half of those assisted were what now would be called the "unemployable" or, as they were then called, the incapacitated. By far the next largest group was the aged. For the first time it was possible to give direct relief to the aged; previously, the only care available had been in the Hone for the Aged and Infirm. The blind constituted only five per cent of the total and Mothers" Aid cases only three per cent. Table VII shows the striking fact that of the total number of cases helped 64.5 per cent were single individuals. This is important to keep in mind when evaluating the low level of relief noted above. It is accounted for by the fact that K.E.R.A. funds were providing, for the most part, for family groups with employable members. The large percentage of aged in

\footnotetext{
21. Ibid.. p. 23.
} 
Table V

City Division, Direct Relief Case Loads by Months, from September, 1934 through August, 1940.

Month

Fiscal Year

$1934-135 \quad 1935-136 \quad 1936-137 \quad 1937-138 \quad 1938-139 \quad 1939-140$

\begin{tabular}{|c|c|c|c|c|c|c|}
\hline September & 418 & 923 & 1,004 & 976 & 943 & 1,219 \\
\hline October & 446 & 968 & 995 & 757 & 938 & 1,148 \\
\hline Notember & 491 & 1,040 & 1,039 & 810 & 955 & 1,129 \\
\hline December & 570 & 1,002 & 1,073 & 1,000 & 982 & 1,104 \\
\hline January & 649 & 1,171 & 1,173 & 1,472 & 1,033 & 2,056 \\
\hline February & 822 & 1,218 & 678 & 1.398 & 1,061 & 2,034 \\
\hline March & 796 & 1,235 & 904 & 1,141 & 1,107 & 1,256 \\
\hline April & 819 & 1,293 & 961 & 1,157 & 1,121 & $1,211_{4}$ \\
\hline May & 827 & 1,232 & 983 & 1,114 & 1,126 & 1,189 \\
\hline June & 850 & 1,249 & 962 & 1,119 & 1,121 & 1,149 \\
\hline July & 868 & 1,241 & 959 & 948 & 1,137 & 1,017 \\
\hline August & 903 & $1,21,2$ & 929 & 942 & 1,139 & 1,007 \\
\hline $\begin{array}{l}\text { Average } \\
\text { for Year }\end{array}$ & & 1,155 & 972 & 1,055 & 1,055 & 1,293 \\
\hline
\end{tabular}

Source: City of Louisville, Department of Public Welfare, Annual Reports. 


\section{Graph I}

Comparative Pelief Loads, Monicipal

Bureav of Social Service.

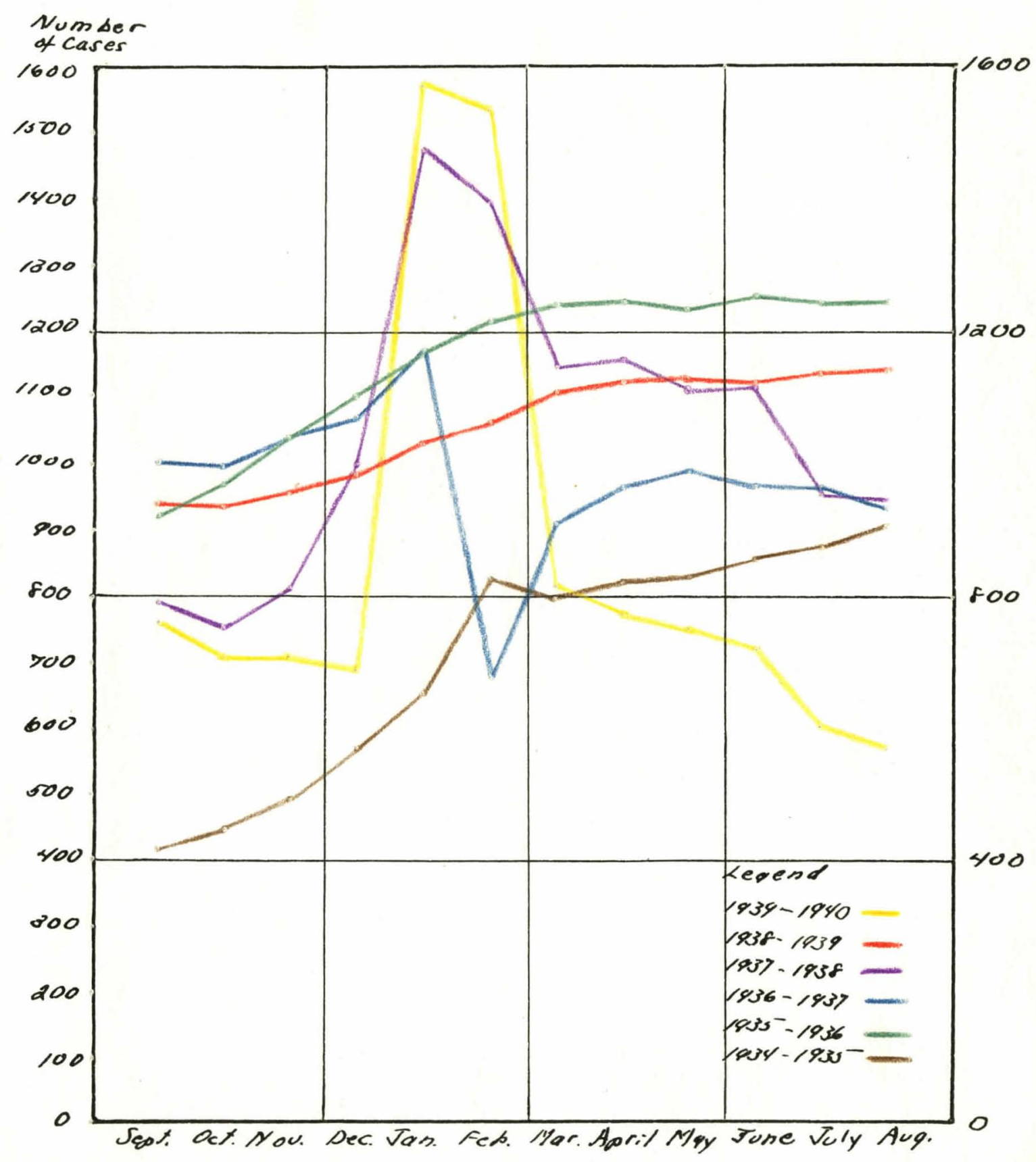

Source: See Table II. 
addition to the small percentage of blind cases was a major factor in giving this unusual distribution.

Beginning on September 1, 1935, the name of the agency was changed to the Municipal Bureau of Sociel Service in recognition of the fact that the City Division was contributing more than relief to the services of the community. The fiscal year ending in August, 1936 was one of great stress and change. Federal funds administered by the city for the relief of the employables were discontinued in Deoember, 1935. State funds were granted from December, 1935 to April, 1936. Discontinuance of state aid threw the entire burden of helping the employable cases on the city. The Bureau had no funds for aiding this group. In June, 1936, it embarked on the policy, which it has pursued until very recently, of granting relief only to unemployable individuals and families.

During the year 1935-1936, the M.B.S.S. spent $\$ 221,262$ of city funds, $\$ 62,342$ of state funds and $\$ 161,926$ of federal funds obtained through the Kentucky Emergency Relief Administration. From Table $V$ we see that the average monthly case load had increased to 1,155. This increase was characterized by a steady gain up to March, 1936, at which time there was a definite leveling off. The relief grants during the year were appreciably higher although still woefully inadequate, hovering between fourteen and sixteen dollars per month. The percentage of the cases falling into the various categories remained relatively the same. There was a loss of six per cent in the "incapacitated" class and a gain of three 
Percentage of Cases Falling into Various Categories, Direct Relief Case, Load, for Fiscal Years 1935-1939.

Classification

Fiscal Year

\begin{tabular}{|c|c|c|c|c|c|c|}
\hline \multicolumn{3}{|c|}{$1934-1935$} & $1935-1936$ & $1936-1937$ & $1937-1938$ & $1938-1939$ \\
\hline \multicolumn{2}{|c|}{ Incapacitated } & 51 & 45 & 46 & 58 & \\
\hline \multicolumn{2}{|l|}{ Aged } & 38 & 41 & 33 & 13 & 4.2 \\
\hline \multicolumn{2}{|l|}{ Blind } & 5 & 3 & 3 & 2 & 3.4 \\
\hline \multicolumn{2}{|c|}{ Mothers' Aid } & 3 & 3 & 4 & 4 & 13.2 \\
\hline \multicolumn{2}{|l|}{ Beggars } & 1 & (a) & (a) & & \\
\hline \multicolumn{3}{|c|}{$\begin{array}{c}\text { Insufficient } \\
\text { Income }\end{array}$} & (a) & (a) & (a) & 1.2 \\
\hline \multicolumn{3}{|c|}{ All Others } & (a) & (a) & (a) & $4 \cdot 9$ \\
\hline \multicolumn{2}{|c|}{ Unemployment } & & (a) & (a) & 9 & 1.4 \\
\hline \multicolumn{2}{|c|}{ Flood Emergency } & & & (a) & & \\
\hline \multicolumn{2}{|c|}{ Dependent Mothers } & & 4 & 9 & 11 & \\
\hline \multicolumn{4}{|c|}{ Chronically IIl } & & & $45 \cdot 2$ \\
\hline \multicolumn{4}{|c|}{ Temporarily III } & & & 13.2 \\
\hline \multicolumn{4}{|c|}{ Non-support } & & & 8.1 \\
\hline \multicolumn{4}{|c|}{ Light Work } & & & 5.4 \\
\hline \multicolumn{4}{|c|}{ Mentally III } & & & 3.8 \\
\hline \multicolumn{4}{|c|}{ Undiagnosed } & & & 0.9 \\
\hline \multicolumn{4}{|c|}{ Miscellaneous } & & & 0.1 \\
\hline \multicolumn{2}{|l|}{ Total (b) } & 98 & 96 & 95 & 97 & 105.0 \\
\hline \multicolumn{7}{|c|}{$\begin{array}{l}\text { (a) Less than one per cent. } \\
\text { (b) These figures seem to be approximate only since they do not total } \\
\text { correctly. }\end{array}$} \\
\hline \multicolumn{7}{|c|}{$\begin{array}{l}\text { Source: City of Louisville, Department of Welfare, Annual Report for } \\
\text { the Fiscal Year Ended August } 31,1938, \text { p. } 4 . \\
\text { City of Louisville, Department of Public Welfare, Annual } \\
\text { Report for The Fiscal Year Ended August } 31,1939, \frac{1}{\text { p. } 30 .}\end{array}$} \\
\hline
\end{tabular}


per cent in the aged group. As the county again gave some blind pensions, the Bureau did not have so much responsibility in that area. The most important new group was "dependent" mothers. This included mothers ineligible for Mothers' Aid and consisted principally of unmarried mothers. There was a very definite increase in the number of family as opposed to single individual cases. As has been shown, this second period of derelopment, from September, 1932 through August, 1936, was characterized by far reaching changes in policy. The agency began to operate on a year round basis. The City Division was established. This was the period of federal aid under the Federal Emergency Relief Administration. There was a definite increase in the amount of money appropriated by the city. The city began to as sume responsibility for other classes than the able-bodied unemployed. When the county discontinued pensions for the aged and the blind early in 1934, it took over the care of these groups. It widened its intake policy to include persons eligible for but not receiving Mothers' Aid. From 1935 through 1940 the city bore part of the cost of this program. The first real assumption of responsibility on a permanent basis was the transfer of "chronic dependents" from the Family Service Organization. This period marks the beginning of the policy of using city funds for "unemployables" only. It includes the only time during which there was any state aid to the city for public assistance. The city was beginning to realize that it was facing a permenent "emergency." Although the Bureau continued to operate on a hand to mouth basis, there was an increasing awareness of its continuing function in the 
Table VII

Family And Single Person Cases Receiving Relief for Fiscal Years 1935-1939.

Total Single

Total Family Person Relief

Percentage Percentage Relief Cases Cases Cared

of Family

Of Single

Fiscal Year

Cared for

For

Cases

Person Cases

$1934-1935$

3,011

5.219

35.5

$64 \cdot 5$

1935-1936

6.534

7,170

4.0

56.0

1936-1937

5.902

5,591

51.0

49.0

1937-1938

7,952

4,717

62.7

37.3

$1938-1939$ (a) $\quad 5,738$

3.528

61.9

38.1

(a) Figures for this year are for the first nine montis only. The percentages are indicative of the nature of the case load, but the figures for total cases are not comparable with those for the other years.

Source: Hosch, Melville, Supporting Data to Budget Request for the Municipal Bureau of Social Service, September 1, 1939 .... through August 31, 1940, forwarded, to the Director of Fublic Welfare, Director of Finanoe and President of the Board of Aldermen on June $1_{4}, 1939$. Table XII. 
cormunity. Behind the present depression, it was seen that there had been for many years a large group in serious need of help. The city was gradually becoming aware of its responsibility. The transfer of cases from the private agency was very significant as an indication of this trend.

\section{Local Responsibility, September, 1936-August, 1940.}

In considering this period wo must keep in mind the fact that at this time the federal goverment was assuming considerable responsibility through the works program. The only Social Security program in operation in Kentucky was that of old Age Assistance.

The year ended in August, 1937 was disrupted by the catastrophic flood, which occurred in January and February, 1937. By this time the W.P.A. program had got fairly well under way. The city administration considered that it had no responsibility for persons able to work. Therefore no provision was made for assistance to this group, even as a temporary measure or to tide over those awaiting W.P.A. assignment. The American Red Cross supplemented the funds of the Bureau to a very great extent by assisting those clients who had been affected by the flood, not only during the crisis but also until rehabitation had been effeoted.

The advent of the Social Security program and the adoption of Old Age Assistance by the State in August, 1936 reduced the responsibility which the Bursau took for the aged. 
It continued, however, to make investigations for admission to the Home for The Aged And Infirm. The policy was to admit only those persons unable to adjust in the community and for whom institutional care was the only posible plan. Although there was no definite rule, only those sixty years of age or over were admitted to the Home.

The Mothers' Aid program was financed jointly by the city and the county. As a general policy, it accepted for care mothers with dependent ohildren when the father was dead, in the penitentiary, in the home but permanently incapacitated or, in carefully selected cases, when the father had deserted. It accepted no mothers with only one child or with children who would be selfsupporting if they could find work. Bocause of limited funds, the Mothers' Aid Department did not accept ceses in which the man was an institutional case but still in the home where the living standards were low or the morals questionable. No unmarried mothers were eligible. The Bureau investigated these cases and provided temporary help pending acceptance by Mothers' Aid. The Bureau defined its responsibility as the care of families and individuals "where the primary need appears to be an economic one because of no stable, full-time wage earner, due either to some physical or mental disability or incompetence, death of the wage earner, old age, blindness, insufficient income or unemployment." ${ }^{23}$ We see from Table VI, however, that there was relatively little change from the previous year in the types of Book, compiled March, 1937, typewritten, unnumbered pages... 
cases cared for. The most marked drop oame in the aged group, as would be expected because of the old Age Assistance program. The percentage of dependent mothers almost doubled. The average monthly case load shows a decided decrease from the previous year. The major part of this was due to the assumption of responsibility for flood sufferers by the American Red Cross. Even in the months before the flood, the case load was fairly low. However, it seems to be typical that the load is low in the fall, and we notice that in January, 1937 there were approximately as many families being aided as had been the year before.

Standards of relief were, on the whole, slightly higher than the year before, except during February, 1937. However, there were relatively fewer single person cases, so that the relief grants per person were a few cents lower. Some city financed work relief was in operation. It was limited to work for the various private agencies who were members of the Community Chest. The wages were at the rate of twenty cents an hour for slow persons and twenty-five cents for those capable of doing a fair day's work. The amount of this work relief was negligible.

The year 1937-1938 was also one of change. Up to July l, 1938, aid continued to be given to persons eligible for old Age Assistance. At that time, on the basis of inadequate funds, all 25 these persons were sumnarily dropped. This year was marked by the gradual transfer back to the Bureau of the families who had been

24. Ibid.

25. City of Louisville, Department of Public Welfare, Annual Report for The Fiscal Year Ended August 31, 1938, pp. 15 and 17..... 
cared for by the American Red Cross. Drastic reductions in W.F.A. employment made some assistance to the employable group imperative during February and larch, 1938. This was very definitely on an emergency basis. In April, 1938, families in which there were none but economic problems were transferred from the Family Service Organization. All the previous transfers of families from the Family Service Organization had been made gradually. There had been detailed sumnaries written and careful plans made. The transfer in April, 1938, however, was made very hastily as requested by the Director of Welfare. The amount of city subsidy which had been intended for the care of these families was withdrawn but was not given to M.B.S.S. It was largely due to this that the Municipal Bureau of Social Service found its funds even more inadequate and was forced to discontinue aid to the aged. Because of the 0ld Age Assistance program, this action was considered justified on the basis that the responsibility belonged elsewhere even though it had not been assumed.

There were never any statutory limitations to the intake policy. All those in force were determined by the executives of the Bureau and approved by the Director of Welfare. We find it commonly said that these policies were dictated by expediency and lack of funds. It is obvious that such a statement does not deal with causative factors. There were many reasons for the lack of funds. Louisville witnessed no riots, no hunger marches. A large part of the population was unaware of the conditions. There was

26. City of Louisville, Municipal Bureau of Social Service, Memorandum to Staff Dated May 1, 1938. 
lack of aggressive and vocal leadership. Although there were many thoughtful persons concerned about the situation, there was little social action. The community was uniformed and, therefore, unconcerned. Except for the emergency period noted above, the policy was continued of giving no relief to the so-called employable group. The unemployable group included persons diagnosed by physicians as totally unable to do any work. Those persons diagnosed as having a physical or mental disability but not totally incapacitated were accepted for help or rejected on an individual basis. An attempt was made to utilize all other possible resources. The Bureau did not claim to accept all those in need. The temporarily ill wage earner was eligible for assistance only in extreme emergencies, the degree of which depended on the funds available. In unusual cases, families were accepted for help when the wage earner claimed or appeared to be unemployable, pending the receipt of a medical report. A few cases eligible for Mothers' Aid were cared for if they were in immediate need, but that Department was not able to accept them at once. The dependent mothers category continued to be eligible for relief. Acceptance remained on a strictly individual basis. On the whole, it included unmarried mothers and those ineligible for Mothers' Aid, especially cases of desertion. There were a few cases of supplementation in homes where there was employment when the income was obviously inadequate. Selection of these cases was made more difficult because the low relief standards in effect meant that income had to be practically non-existant in order not to exceed the relief 
budget set up. Beginning in May, 1938, a Short Contact Division was organized to deal with emergency evictions among the employable group, to purchase medical appliances when necessary and to deal with similar imperative needs.

The average monthly case load during 1937-1938 increased considerably over the previous year. It showed, by violent fluctuations, the effects of the changing policies discussed above. The distribution of the load was characterized by drastic increases in the number of "incapacitated" and an even more drastic reduction in the aged group. For the first time, there was an appreciable number of cases aided because of the unemployment of the able-bodied wage earner. The dependent mothers' category continued to increase in relative importance. Adequate statistics on the amount of relief granted each case are not available. Figures at hand for a few months would indicate, however, that the grants remained at the same low level.

In the period from September, 1938 through August, 1939, the program of the agency continued to be limited to direct assistance of unemployable families only. Service to employable persons continued to be limited to certification for W.P.A., N.YA., C.C.C., federal surplus commodities and clothing made on a W.F.A. sewing project. By Table VI we see that the once important aged group had become less than five per cent of the total case load. This did not mean, as we will show in the next chapter, that the needs of these persons were being met, but rather that the Bureau decided it was more important to utilize its limited funds in another area. 
Combining the cases know as chronically ill, temporarily ill, mentally ill and able to do only light work, we find that almost seventy per cent of the case load was made up of families in which the problem seemed to be the incapacitation of the wage earner. Fending Mothers' Aid cases more than tripled in relative number. The dependent mothers' category was discontinued but an appreciable number of non-support cases were aided. The Bureau continued to care for a selected number of unmarried mothers.

The proportion of the case load made up of single individuals remained approximately the same for the year ended August, 1939. The average monthly case load was exactly the same as that of the preceding year. There was remarkably little fluctuation in the load during the various months; on the whole, there was a slight increase each month. Instead of decreasing as had been expected, the load continued to increase during the spring and sumer. As a result, relief grants had to be drastically cut in May, June, July and August of 1939. This is reflected in Table VI. Except for these months, there was a considerable increase in the average grants to each case. However, this increase is apparent rather than real. The decrease in the percentage of single person cases obscures the actual situation. As a matter of fact, average grants per individual declined during this year.

The fiscal year 1939-1940 began with a letter, dated August 18, 1939, to the Director of Public Welfare from the Superintendent of the Municipal Bureau of Social Service, stating that he hoped to maintain a fairly even case load throughout the year 
by means of limiting the number of cases accepted. He was prepared to refuse aid to persons in need as great as those who were receiving relief. This attitude was justified by him on the basis that, otherwise, funds would be spread so thin that all would be hungry. It seemed better to help a few on a bare subsistence level than to help more on an even more inadequate basis. The procedure was to balance the number of cases accepted each week with the number closed.

The policy continued to be one of refusing direct relief to employable families. In the fall there were 2,000 persons laid off the W.F.A. because of the rule limiting continuous employment to eighteen months. The winter was one of record breaking severity. Continued cold and abnormal snow fall made outside work impossible. Pressure from those in need finally resulted in additional appropriations from the city. Thus, during January and February, 1940, for the first time since 1937, it was possible to do away with categorical intake and to give assistance according to need. During these months, temporary assistance was given to the employable group. After the coldest weather was passed, the Bureau reverted to its old restrictive policy. However, there was slight relaxation in rules. Because of these additional funds, it was possible to viden the range of aid to the physically handicapped and to continue to help in cases of eviction. Assistance could be given to all persons who were seriously ill and to women who were pregnant; previously families were eligible only during the illness of the normal wage earner, the last month of pregnancy 


\section{7}

and during quarantine.

We see from Table $V$ the striking rise in the case load, which was expecially marked during January and February but was evident throughout each month. Table VI shows the extreme inadequacy of the relief granted.

This period, from 1936 through August, 1940, marks the consistent administration of the arbitrary policy of refusing aid to the so-colled employables. Except for two emergency periods, this policy was tolerated by the agency, not because there was no realization of its injustice, but solely on the grounds of inadequate funds. The only exemption was aid in cases of eviction. This particular type of assistance was given because of community pressure. There is a convincing amount of public appeal in the picture of a family set out on the streets in the cold and rain.

It was very significant that the Bureau continued to transfer cases from the Family Service Organization. This was indicative of a trend toward realization on the part of the city that it had a definite duty toward dependent families. It meant the declaration of policy of public responsibility and recognition of the fact that public authority and not private philanthropy should deal with the problem of dependency. By the end of this period, the private agency had redefined its function and accepted no families in which relief was the only service requested. Although there were many families who were thereby left without rescurces, this policy was a step toward a planned program of public Report for The Fiscal Year Ended August $31,1940, \mathrm{pp}, 2-6 . \ldots$ 
Graph II

Average Monthly Direct Relief Grants Per Case, from September, 1935 through August, 1940.

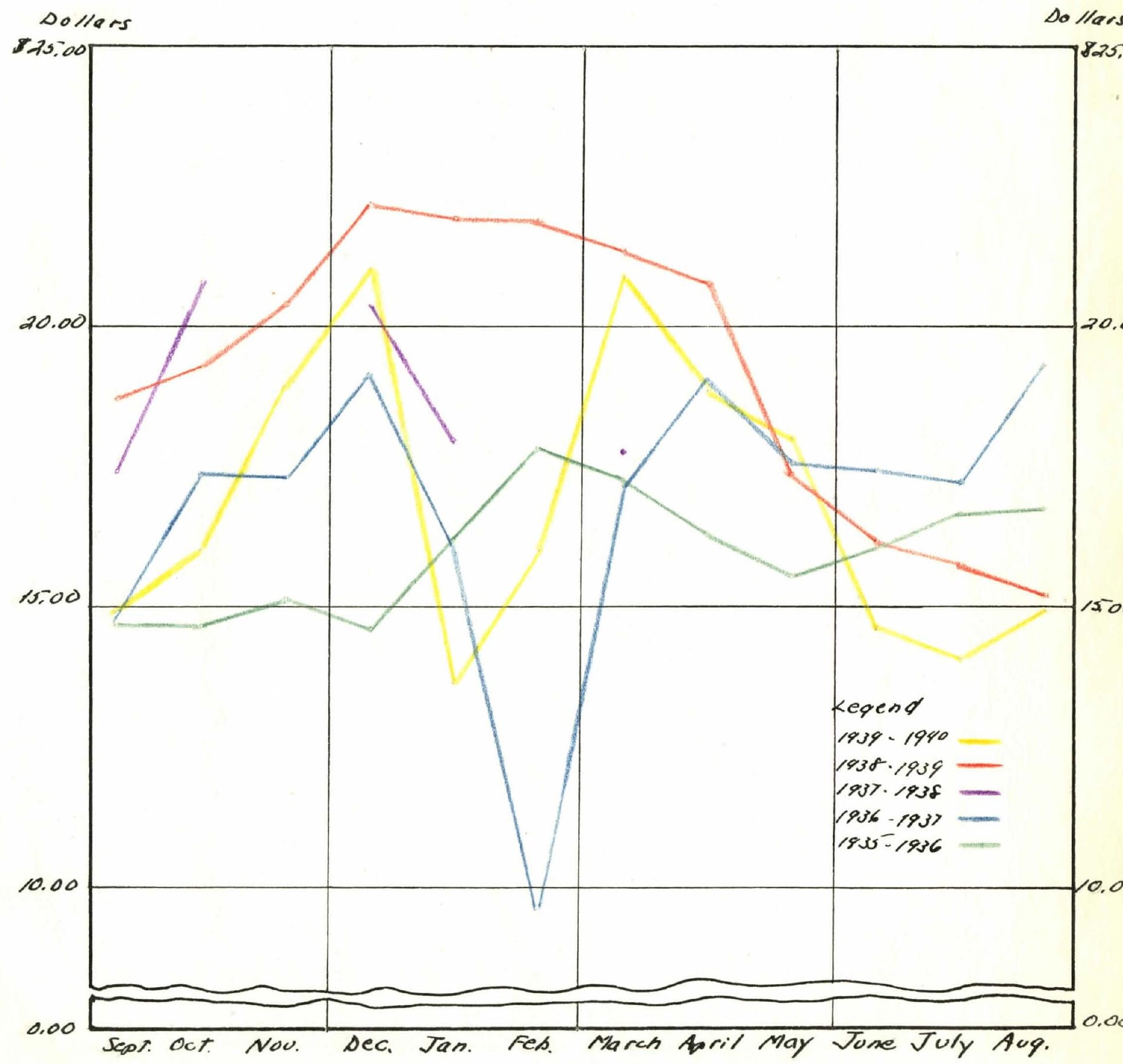
source: See Table IV. 
Graph III

Average Monthly Direct Aelief Grants oer Individual from September, 1935 through Auqust, 1980.

Dollars

810.00

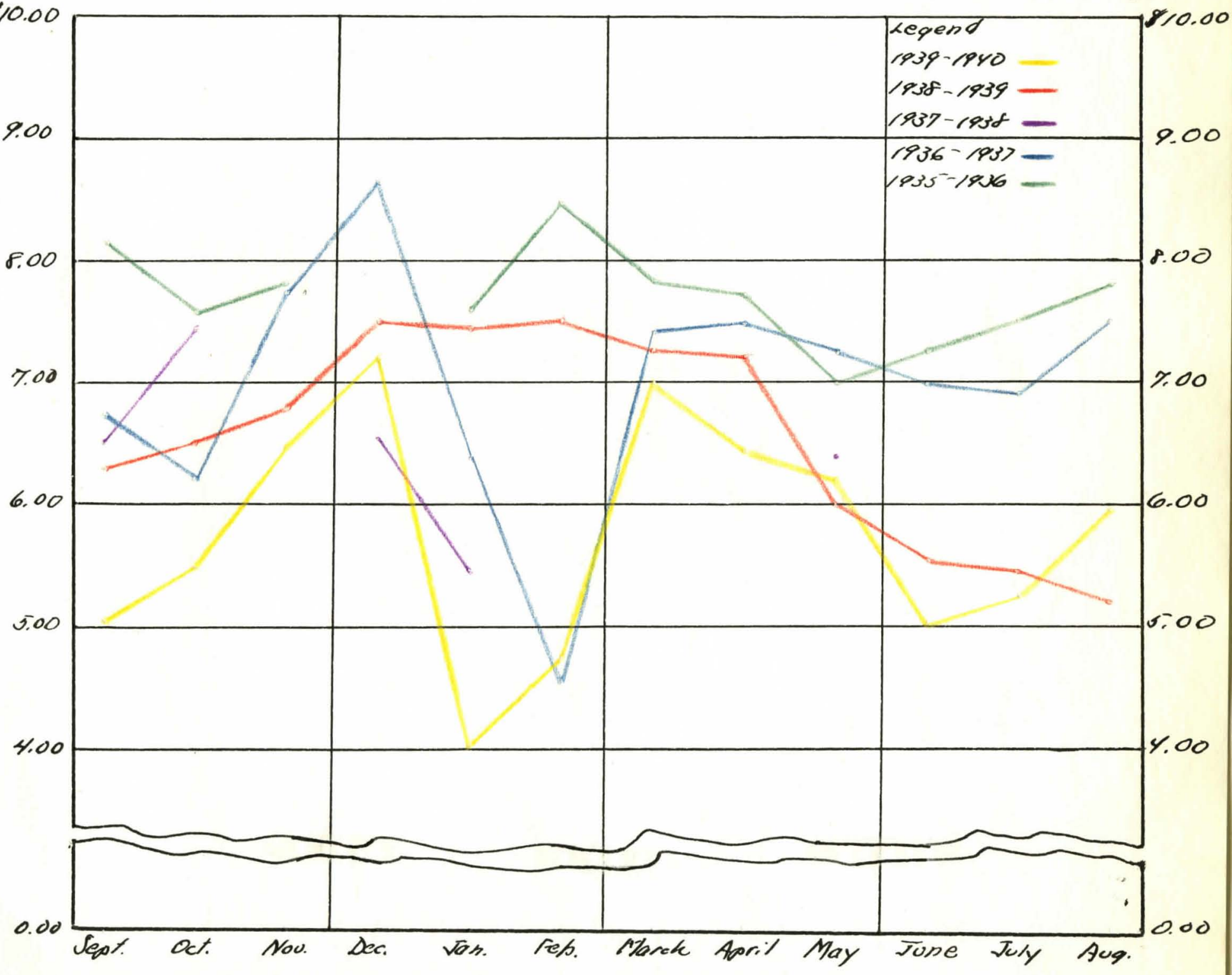

Soure: Cixy of hovisoille, Desartment of Aoblic Welfare. Annual Deports. 
assistance.

This recent period shows the continuing increase in the proportion of the case load classified as incapacitated. From Graph I we see the erratic quality of this case load, with decided increases in 1937 and 1939 when emergency help was given the unemployed. The drop in February, 1937 was caused by the flood and aid from the American Red Cross. The discontinuance, in July, 1938, of assistance to individuals eligible for Old Age Assistance will be discussed further in the next chapter. Throughout the entire history of the Municipal Bureau of Social Service, policies have been based on expediency. We see in Graph I a jumbled mass of lines. Graphs II and III show average relief grants fluctuating wild ly. If there is any trend, it seems to be to cut the amount of relief grants during the winter when need is greatest, because of the necessity to spread rescurces thin; and to cut during the summer, when the end of the fiscal year is approaching and funds are running low. 
II. THE RELIEF PROBLEM IN LOUISVILLE 


\section{THE RELIEF PROBLEM IN LOUISVILLE}

Louisville is a city of over three hundred thousand persons, about fifteen per cent of whom aro negro. Less than nine thousand, or approximately three per cent, are foreign born. The city is situated geographically relatively near to the population center of the United States. It is the only large, industrial city in a predominately agricultural state. In wages and standards of living it belongs between comparable cities of the North and the South. Not wealthy, neither is it unusually poor. It has many, highly diversified manufacturing industries and acts as a distributing center for most of the state and a large part of the South.

\section{A. Relief Appropriations and Average Grants.}

In the previous chapter we remarked on the amounts of the general relief grants for each year. Graph II, based on Table IV, gives these pictorially. Graph III gives the average grant to each individual rather than to each case. Because of the varying proportion of the case load composed of family and single person cases, these two charts do not precisely correspond. They do, however, show the same general trends. As pointed out above, these charts indicate the capricious nature of the relief grants. It has not been possible for the agency to approximate the needs of the clients in determining the grants to be made. Rather, it has had to distribute the small sums at hand in what seemed the most Census of Population, Volume III, Part I, Table 12, p. 912. 
equitable manner.

Table VIII gives the amounts of city funds spent by the agency for general relief for all years since its establishment.

Table VIII

\begin{tabular}{lr}
\multicolumn{2}{c}{$\begin{array}{c}29 \\
\text { Relief Expenditures. }\end{array}$} \\
Fiscal Year & Amount \\
$1930-1931$ & $\$ 111,631$ \\
$1931-1932$ & 164,180 \\
$1932-1933$ & 370,000 \\
$1933-1934$ & 354,904 \\
$1934-1935$ & 126,294 \\
$1935-1936$ & 221,262 \\
$1936-1937$ & 198,311 \\
$1937-1938$ & 234,314 \\
$1938-1939$ & 240,000 \\
$1939-1940$ & 258,739
\end{tabular}

Most striking is the impetus which was given by the Federal Emergency Relief Administration program. During those years, 19331934, the appropriations by the city were markedly higher. Since then, they have decreased very considerably. For the last three years, there has been a slight, steady gain, but, on the whole, remarkable uniformity.

The significance of the facts may be clarified by comparison with the situation as it is in other cities in the United States. Table IX shows the average amount of relief granted to families and to individuals in various cities in January, 1939 and 1940. The average per family in these nine cities varied in January, 1939 from $\$ 27.92$ in St. Louis to $\$ 51.27$ in San Francisco.

29. City of Louisville, Department of Public Welfare, Annual Keports, except for 1932-1933. A letter to Nayor Harris on from C. D. Hall, Comptroller, dated September 6, 1933, gives city appropriation for that year. 
Table IX

Average Amount of General Relief Grants in Selected Cities

City

Average Amount per

Family Case

Januery January

$1939 \quad 1940^{\circ}$

(a) (a)

Baltimore

Buffalo

Cincinnati

Cleveland

Detroit

Mi I waukee

Minneapolis

Newark

New Orleans

Pittsburgh

Rochester

St. Louis

San Franoisco
\$4. 38

(a)

32.73

35.97

30.00

34.13

37.18

(a)

(a)

46.49

27.92

51.27
$\$ 43.94$

24.99

34.15

(a)

36.39

32.97

36.98

(a)

(a)

47.78

22.12

$44 \cdot 28$
Average Amount per One-person Case

January January $1939 \quad 1940$

(a)

(a)

$\$ 20.67 \$ 20.10$

(a)

19.01

15.25

15.67

26.45

(a)

11.70

11.96

20.60

20.09

21.45

$25 \cdot 32$

(a)

(a)

(a)

(a)

18.40

19.13

9.03

8.83

21.65

20.58

(a) Figures not available.

Source: United States, Social Security Board, Social Security Bulletin, Volume III, 1940, Table 4, p. T2; and Volume II, 1939. Table 4. p. 38. 
In Louisville, for the same month, the average per case was $\$ 21.95$. Although the figure for Louisville is not strictly comparable because it is an average including some single person cases, it is evident that in Louisville the standards are much lower than in other cities. In January, 1940, the range in nine cities was from $\$ 22.12$ in St. Louis to $\$ 47.78$ in Rochester. In Louisville the average was only $\$ 13.67$. Differences in the cost of living in these cities do not vary as greatly as do relief grants. In March, 1941, the index, prepared by the United States Bureau of Labor Statistics based on Washington, D. C. as 100, for Buffalo, Cincinnati, Cleveland, Detroit, Milwaukee, Minneapolis, St. Louis and San Francisco, varied from 98.8 in San Francisco to 88.6 in Buffalo. Table $X$ presents data on per capita expenditures for public and private assistance in urban areas more or less comparable with Louisville on a population basis. This table is extremely interesting. of the twenty cities, Louisville stood second from the bottom in 1939 in the total per capita expenditures for public assistance. Of five other Southern cities, only Richmond fell below Louisville. The per capita expenditures ranged from $\$ 38.55$ in Toledo, Ohio, to $\$ 10.57$ in Louisville and $\$ 10.15$ in Richmond. The amounts for general relief ranged from $\$ 15.18$ in Rochester to $\$ 0.19$ in Birmingham, while the Louisville area spent $\$ 0.81$ per person for this purpose. The expenditures for special types of public assistance were relatively highest in Denver with 15.22 and lowest in Richmond $(\$ 0.80)$ while Louisville was again far down Estimated Intercity Differences in Cost of Living, March 15, 1941, Washington, 1941, Table 2 . 
Table X

Per Capita Expenditures for Public and Private Assistance And Earnines of Persons Employed on W.P.A. Projects, In Selected Cities, $1939 \cdot 1$

\section{Expenditures}

Urban Area

Toledo (a)

Mi lwaukee (a)

San Francisco (a.)

Pittsburgh (a)

Springfield, III. (a)

Denver (a)

Columbus, 0. (a)

New Orleans (c)

Indianapolis (a)

Rochester (b)

Cincinnati (a)

Portland, Ore. (a)

Kansas City, Mo. (a)

Fort Worth

Atlanta (a)

Jersey City (b)

Birmingham (a)

Memphis (a)

LOUISVILLE (a)

Richmond (b)
Public Funds

Special

Types of

Total

$\$ 38.55$

35.44

33.44

31.72

30.01

29.25

29.13

28.32

27.57

26.74

24.44

23.20

23.14

19.50

19.04

18.67

16.99

21.21

10.57

10.15
Publio

Ass't

Relief

2

$\$ 4.60$

8.44

7.72

$\$ 4.99$

5.05

7.43

13.09

4.99

2.73

3.86

0.97

3.56

3.71

15.18

4.98

3.29

2.21

1.27

0.55

5.96

0.19

0.39

0.81

1.63

\section{72}

15.22

6.00

3.84

5.83

5.67

4.63

6.71

4.63

3.93

1.33

1.91

1.15

2.56

1.41

0.80
Privato

Funds

W.P.A.

Earnings

3

\$28.96

21.95

18.29

15.07

$\$ 0.02$

0.17

0.33

0.19

20.30

11.30

19.27

23.51

0.24

0.12

0.07

0.27

18.03

5.99

14.83

13.20

0.27

0.10

0.31

0.08

\subsection{0}

14.30

0.34

$$
17.16
$$

0.02

0.19

0.02

10.80

15.65

9.26

0.15

8.35

0.26

7.72

1. Based on population figures as given by the 1930 Census.

2. Includes direct relief, work relief and statutory aid to Veterans administered on the basis of need.

3. Earnings of persons employed on projects operated by W.P.A. in these areas.

(a) Territory included is county.

(b) Territory included is city.

(c) Territory included is parish.

Source: United States, Social Security Board, Social Security Bulletin, Volume III, 1940, Table 4, pp. 60-61. 
the list $(\$ 1.4 .1)$. The expenditures for W.P.A. wages were similarly varient. In Toledo they were $\$ 28.96$ per inhabitant and in Louisville \$8.35, while the lowest was $\$ 5.99$ in Rochester. The expenditures for relief from private funds are relatively insignificant. They seem to bear little relation to the level of relief in general. In Louisville, they were comparatively high.

We see from this table that the Municipal Bureau of Social Service in Louisville was not the only public agency operating in a restricted manner. Kentucky has only one public assistance program, that of Old Age Assistance. The average grant does not approximate adequacy. The administrators realize this but point out that it is of help to aged persons being cared for by relatives. The Old Age Assistance Department has not been able to care for all needy aged. At all times it has had a waiting list of several thousand. At the time of writing, no applications filed in 1940 or 1941 have been investigated, except in instances of extreme emergency. While the Bureau discontinued aid to this group, it did so with full knowledge of the circumstances. The Director of Public Welfare said that they did so to meet "the most acute crisis in the history" of the Bureau and in the hope that by so doing they would have sufficient funds to last the remainder of the year. The members of the State Old Age Assistance office told representatives of a comnittee appointed by the Mayor to investigate relief conditions "that some of the elderly people who have no resources whatever, although legally wards of the state, are taking their 
Average Payment per Recipient of Old Age Assistance In Kentucky.

Month Fiscal Year

$\begin{array}{lcccc} & 1935-1936 & 1936-1937 & 1937-1938 & 1938-1939 \\ \text { July } & (\mathrm{b}) & \$ 9.95 & \$ 8.98 \\ \text { August } & 7.34 & 9.94 & \\ \text { September } & & 9.16 & 9.95 & \\ \text { October } & 9.56 & 9.95 & 8.81 \\ \text { November } & & 9.73 & 10.04 & \\ \text { December } & & 9.98 & 9.81 & 8.71 \\ \text { January } & \text { (a) } & 10.03 & 9.56 & \\ \text { February } & \text { (a) } & 10.05 & 9.38 & \\ \text { March } & \text { (a) } & 10.03 & 9.37 & \\ \text { April } & \text { (a) } & 9.98 & 9.36 & \\ \text { May } & \text { (a) } & 9.96 & 9.35 & \\ \text { June } & \text { (a) } & 9.95 & (\mathrm{~b}) & \end{array}$

(a) Not administering O.A.A. under plan approved by the Social Security Board.

(b) Federal funds available but no payments made.

Source: United States, Social Security Board, Annual Report 1937. Table C-7, p. 121; 1938, Table D-8, p..211; 1939, Table D-10, p. 292. 
turns at the garbage cans of the restaurants of the city.

Table $\mathrm{X}$ shows the relatively low expenditures on the part of the W.F.A. in the city. Since the Municipal Bureau gave no aid to employables, it would have been very desirable to have an adequate works program. This has never been the case. There have always been large numbers ineligible because of technicalities. For example, the person applying may not have a satisfactory work history. He is not eligible for W.P.A. He is the type of marginal worker who cannot find private employment. Perhaps the person applying is not the normal wage earner in the family. In many instances he or she was able to do only light work but there has been a great dearth of light work jobs available on W.P.A.

It has become apparent that W.P.A. wages are adequate only for a small family. The man with three or more dependents can manage only on a subsistence level, while those with large families are often in dire need. The only service the Municipal Bureau of Social Service has been able to give is the distribution of W.P.A. clothing, surplus commodities and, recently, certification for food stamps. This has not been adequate. Table XII illustrates what other cities have done. Of the twelve for which figures were available for the year 1940, eleven were supplementing W.P.A. wages. In Milwaukee over twenty per cent of the case load was made up of families with W.P.A. income.

Table XII invites interesting comparison in other

32. Ibid., January 6, 1940 . 
Table XII

General Relief Cases in Households Receiving Other Types of Income Or Assistance in Selected Cities, January, 1939 and $1940 \ldots$

City

Per Cent of General Relief Cases in Households Receiving

\begin{tabular}{|c|c|c|c|c|c|c|c|c|c|c|}
\hline & \multicolumn{2}{|c|}{$\begin{array}{l}\text { Unemployment } \\
\text { Compensation } \\
\text { Benefits }\end{array}$} & \multicolumn{2}{|c|}{$\begin{array}{l}\text { Earnings } \\
\text { from } \\
\text { Employment }\end{array}$} & \multicolumn{2}{|c|}{$\begin{array}{l}\text { W.P.A. } \\
\text { Earnings }\end{array}$} & \multicolumn{2}{|c|}{$\begin{array}{l}\text { Old Age } \\
\text { Assistance }\end{array}$} & \multicolumn{2}{|c|}{$\begin{array}{l}\text { Aid to } \\
\text { Dependent } \\
\text { Children }\end{array}$} \\
\hline & 1939 & 1940 & 1939 & 1940 & 1939 & 1940 & 1939 & 1940 & 1939 & 1940 \\
\hline $\begin{array}{l}\text { Baltimore } \\
\text { Buffalo } \\
\text { Cincinnati } \\
\text { Cleveland }\end{array}$ & $\begin{array}{r}8.1 \\
(\mathrm{~b}) \\
17.3\end{array}$ & $\begin{array}{l}0.6 \\
0.5 \\
0.9 \\
0.1\end{array}$ & $\begin{array}{r}1.2 \\
8.6 \\
(\mathrm{~b}) \\
11.8\end{array}$ & $\begin{array}{l}0.7 \\
9.0 \\
3.8 \\
4.4\end{array}$ & $\begin{array}{l}1.6 \\
0.3 \\
\text { (b) } \\
\text { (b) }\end{array}$ & $\begin{array}{r}9.6 \\
1.4 \\
10.4\end{array}$ & $\begin{array}{l}1.3 \\
2.0 \\
\text { (b) } \\
\text { (b) }\end{array}$ & $\begin{array}{l}2.2 \\
2.4 \\
4.5 \\
0.4\end{array}$ & $\begin{array}{r}31.1 \\
1.1 \\
(\mathrm{~b}) \\
\text { (b) }\end{array}$ & $\begin{array}{r}34.9 \\
1.2 \\
0.1 \\
(0)\end{array}$ \\
\hline $\begin{array}{l}\text { Detroit } \\
\text { Milwaukee } \\
\text { Minneapolis } \\
\text { Newark }\end{array}$ & $\begin{array}{r}10.4 \\
20.8 \\
26.4 \\
4.1\end{array}$ & $\begin{array}{l}0.6 \\
0.7 \\
0.2 \\
1.1\end{array}$ & $\begin{array}{r}5.9 \\
4.6 \\
0.5 \\
25.7\end{array}$ & $\begin{array}{r}5.5 \\
5.0 \\
1.2 \\
23.1\end{array}$ & $\begin{array}{l}3.1 \\
1.1 \\
\text { (b) } \\
\text { (b) }\end{array}$ & $\begin{array}{r}8.7 \\
20.1 \\
16.1 \\
3.3\end{array}$ & $\begin{array}{l}2.8 \\
1.0 \\
3.9\end{array}$ & $\begin{array}{l}3.3 \\
2.5 \\
5.1\end{array}$ & $\begin{array}{l}0.1 \\
3.5\end{array}$ & $\begin{array}{l}3.8 \\
0.2 \\
4.2\end{array}$ \\
\hline $\begin{array}{l}\text { New Orleans (a) } \\
\text { Pittsburgh } \\
\text { Rochester } \\
\text { San Franoisco }\end{array}$ & $\begin{array}{l}3.0 \\
5.8 \\
3.0\end{array}$ & $\begin{array}{l}0.5 \\
0.6 \\
\text { (b) }\end{array}$ & $\begin{array}{l}\text { (b) } \\
1.1 \\
\text { (b) }\end{array}$ & $\begin{array}{r}(b) \\
y_{4.7} \\
(b)\end{array}$ & $\begin{array}{l}0.7 \\
0.6 \\
2.3\end{array}$ & $\begin{array}{l}2.7 \\
3.9 \\
8.1 \\
0.7\end{array}$ & 4.8 & $\begin{array}{l}1.3 \\
(b) \\
5.0 \\
(b)\end{array}$ & $\begin{array}{l}\text { (b) } \\
2.7\end{array}$ & $\begin{array}{l}1.0 \\
\text { (b) } \\
2.6 \\
\text { (b) }\end{array}$ \\
\hline
\end{tabular}

(a) Figures refer to unemployable oases only; data not available for employable cases.

(b) Figures not available.

(c) Less than one tenth of one per cent

Souroe: United States, Social Security Board, Social Security Bulletin, Volume III, 194U, Table 5, p. 73; Volume II, 1939, Table 7, p. 62 . 
areas. In Louisville persons awaiting or receiving unemployment compensation benefits were not eligible for public assistance. Yet in these other cities they constituted an appreciable, if not large, per cent of the case load. As pointed out in the previous chapter, in Louisville only a few, carefully selected cases were accepted for supplementation when there was income from private employment in the hone. In other cities, however, they were a major portion of the case load.

\section{B. Some Administrative Problems.}

The officials of the Department of Welfare have faced a great many very difficult problems of administration. The most fundamental handicap has been the lethargy of the poople of the city - they have blinded themselves to the facts and have adopted a pollcy of letting sleeping dogs lie. On one occasion the Director of the Department of Welfare gave as a reason for indifference and inaction that there had been no "mass demonstrations of hostility on the part of the relief clientele" or any "bizarre exhibitions of long soup lines, clients invading the City Hall, etc." 33 Some of the officials of the Welfare Department and the Bureau have been aware of the inadequacies of the program. From time to time efforts have been made to educate the public and attempt needed reforms. However, it has been a slow process. In spite of excellent cooperation from the newspapers in the matter of publicity, a large part of the population has been and is unaware of the need existing.

33. Russell, Solon, Evaluation of The Report of The Mayor's Committee on Relief, typewritten, 1939, p. 24. 
It is for this reason that the agency has been impeded by lack of funds. An aroused citizenry would see to it that the agency had an adequate appropriation. Money is always available for functions which are considered fundamentally necessary or sound public policy. The city has been shackled by a constitutional limitation on the tax it can levy for general purposes. The maximum has been levied for years. The city has appealed again and again to the state legislature for additional taxing power. As the Director of Welfare said in 1939, "The past three and one-half years have witnessed the debacle of the State of Kentucky ..... adopting a reprehensible, confiscatory policy so far as tax revenues are concerned. As a result, not only have municipal welfare services been impaired but often essential municipal services as we11." 34 A new resource was opened up in 1940 when the legislature passed a bill permitting the city to apply to relief needs license fee receipts in excess of sinking fund requirements. This has not, so far, produced additional funds.

That the State of Kentucky has not been as quick to recognize its functions as have other states, may be seen from Table XIII. This shows per capita expenditures for all types of public and private social services, including medical and hospital care. Of all the twenty-eight cities for which figures were available in 1938, Louisville stood at the bottom in the per capita expenditures of state monies. Of the seven Southern cities, New Orleans represented the greatest use of state appropriations, 34. Tbid.. p. 24 . 
Table XIII

Per Capita Expenditures for Social Services, by Source of Funds And Urban Areas for 1938.

Total

Public and Public Funds

Urban Area Funds Total Federal State Local

$\begin{array}{lrrrrr}\text { Baltimore } & \$ 27.74 & \$ 19.45 & 7.65 & \$ 4.14 & \$ 7.66 \\ \text { Bridgeport } & 37.87 & 30.18 & 15.71 & 6.81 & 7.66 \\ \text { Buffalo } & 45.35 & 39.09 & 13.09 & 9.26 & 16.74 \\ \text { Hartford } & 45.95 & 32.86 & 16.23 & 8.02 & 8.61 \\ \text { Frovidence } & 46.70 & 35.79 & 20.47 & 7.62 & 7.70 \\ \text { Springfield } & 48.07 & 38.10 & 19.53 & 3.18 & 15.39 \\ \text { Syracuse } & 47.81 & 39.01 & 14.05 & 9.10 & 15.86 \\ \text { Washington } & 33.78 & 25.98 & 13.22 & \ldots .10 & 12.76 \\ \text { Wilkes-Barre } & 61.88 & 56.71 & 37.33 & 17.47 & 1.91\end{array}$

Atlanta

Birmingham

Dallas

Houston

LOUISVI LLE

New Orleans

Richmond

36.64

24.46

24.81

21.94

25.58

41.68

24.57

32.16

21.44

25.47

1.51

17.82

1.24

5.18

18.72

12.10

2.53

2.38

15.96

10.30

1.92

20.23

12.87

1.02

4.09

35.29

27.96

4.44

3.74

18.34

9.51

1.86

6.34

41.71

36.15

25.81

46.39

68.10

37.69

59.67

22.31

3.43

2.89

44.42

37.55

4.25

26.26

38.02

25.25

Dayton

Grand Rapids

46.56

48.4 .9

43.01

30.20

48.03

41.71

28.10

33.59

21.94

56.56

Mi I waukee

St. Louis

42.34

49.71

30.94

24.98

30.60

34.44

14.92

2.93

5.76

6.4 .6

5.76

8.31

3.35

5.27

2.28

3.75

3.81

6.91

45.26

Los Angeles

58.20

38.34

16.49

9.96

9.51

11.89

15.93

11.48

Source: United States, Children's Bureau, The Cormunity Welfare Picture, June, 1939. Table 9, p. 20. The figures for state and local expenditures were changed by the City of Louisville Council of Social Agencies, since the original were incorrect. 
while no cities did not have at least fifty per cent more than Louisville. The State of Kentucky has failed to recognize its responsibility. There is only one state financed program of public assistance, that of old Age Assistance. Except for the brief period between the abandonment of the Federal Bmergency Relief Administration and the beginning of the federal works program, the state has not made any funds available to the city.

The agency has felt, as have all public agencies in the last decade, the effect of changing standards as regards qualifications of personnel. It has always been severly restricted by lack of sufficient personnel. It has been faced with the difficulty of securing trained persons while being forced to pay quite low salaries. In December, 1937, a civil service system was organized for health and welfare employees of the city. Under it, examinations are given for all positions within the Municipal Bureau. The institution of the merit system was a distinct advance and has been of assistance in the selection of personnel. However, the Personnel Commission has found itself at a disadvantage. In its report for 1940 it commented on the difficulty of securing qualified persons at the salaries offered.

About this time and before the Personnel Cormission was fully operative, the Director of Public Welfare discharged arbitrarily a number of the best trained members of the staff. The whole question of administrative standards in the organization became a matter of public controversy. Recognition of the situation was made by the Mayor in November, 1938, when he appointed 
a conmittee to study the relief situation. This committee engaged the services of two persons from the American Public Welfare Association to conduct the study. They reported that Louisville had not pursued an intelligent course and had seriously neglected necessary coordination and cooperation.

".... unlike many other cities, Louisville has not usually negotiated for the care of the various groups ...... by careful inter-agency planning, but ..... has had the attitude of forcing the various federal and state and other local agencies to carry increased responsibility by the method of abruptly dropping off relief for different groups......" 35

This comittee also found that, where the Bureau had accepted responsibility, its assistance had been given on a very low level and with a minimum of planning. The assistance given to unemployables was considered very inadequate.

"There were no regular allowances for health needs; for household expenditures, etc. Because of the failure to meet even the minimun requirements of a minimum budget, the records repeatediy revealed situations frowing more aggravated and requiring a more costly kind of care.

"Insecurity because relief had been granted on a temporary basis rather than on a carefully planned basis so that the dependent family might feel some security in receiving at least their subsistence noeds, is indicated in the records by the large numbers of references that the man or woman was daily growing 'more nervous'; 'more mentally disturbed'; 'more irritable' and 'less able to find their own jobs." 36

The comittee recomended an increased appropriation to the Bureau for relief. "The relief needs of the people of this community can not be met, nor can hunger and actual suffering be prevented under the present budget of the Municipal Bureau of Social Service." The committee also recommended that a new appointment be made to

35. Mallon, John H.; Tachau, Charles; and Dennis, Force, Report of The Mayor's Committee to Consider the Relief Situation in Louisville, Typewritten, Louisville, February 6, 1939, p. 24. 36. Ibid.. p. 25. 
the position of Director of the Department of Public Welfare and urged that the city officials assume more leadership in cooperating with other private and public agencies to provide for all persons in need.

\section{The Need.}

From time to time various studies have been made which give some insight into the need in Louisville.

In the hope of obtaining a more adequate appropriation from the city, the Superintendent of the Bureau conducted a study of the 1,083 families on direct relief during April, 1939. The actual relief given was compared with a standard budget. The food budget was based on the standard established by the United States Depertment of Agriculture (Steibling Diet, Circular \#1757) and adjusted to the retail market price of food in Louisville in April, 1939. Additional quantities of milk were included in the budget when specifically recommended by the physician. Other substitutions and special diets were included under medical supervision. Rent was budgeted at the actual rental paid by individual families at the time of the study. It was recognized that these rentals usually did not insure decent or sanitary housing conditions. The clothing budget used was based on a study of clothing noeds for families on relief in Louisville made by Miss Anne Heines, Executive Secretary of the Louisville Health Council, in April, 1936, adjusted to price levels in April, 1939. A thorough study was made of ten per cent of the direct relief case load. Compari- 
son of the standard budgets with actual family budgets revealed serious deficiencies, even when earned income and all other types of resources had been included. The results of the investigation of ten per cent of the case load were applied to all the families. It was found that, on the whole, the actual fomily budgets were thirty-seven per cent deficient for food; seventy per cent deficient for clothing; ninety-three per cent for household supplies; ninety-four per cent for personal needs; and eighty-seven per cent deficient for school supplies. After April, the situation grew steadily worse until, in $\mathrm{July}$, the food allowances were twentyseven per cent less than they had been in April.

We have already made note of the community pressure toward avoidance of eviction. As a rule, this is shared by the families themselves, who will go without food in order to pay their rent. It is not surprising, therefore, to find that only a negligible proportion of the rents of families were not paid in April, 1939.

The conclusions drawn from this study were stated as follows:

"This study concerned itself only with relief needs and the actual public assistance being given to meet those needs and it did not attempt an evaulation of the results of prolonged relief inadequacies and of the full implications of such inadequacies. Nevertheless, even from the type of data presented ...... it is obvious that our relief situation presents a crisis of major proportions. Even if we confine our emphasis only to the economic implications, the toll that such acute deprivation must inevitably take is staggering when considered in terms of serious, chronic health problems on a

37. Hosch, Melville, Supplementary Data on M.B.S.S. Budgets for the 1939-1940 Fiscal Year, July 15. 1939, pages not numbered. 
mass scale developing from prolonged underfeeding; increased dependency resulting from the extreme deprivations of children in families currently receiving relief; an increased need for institutional care; expanded medical facilities needed to provide for increased physical problems, traceable, in part, to inadequate relief; a destruction of faith on the part of the dependent population in the democratic processes of government; and a host of other social, political and economic problems which even a superficial consideration of the meaning of the data of this study suggests." 38

The above study by the Superintendent of the Bureau gives some picture of the families who were eligible for and receiving assistance.

What were the effects of the restrictive intake policy discussed in the previous chapter? There is not much reliable data on the subject. The Bureau made a study of the refusals in the Intake Department of families applying for help during December, 39 1938 and January, 1939. W.P.A. assignments were not being made at that time. Twenty per cent of the refusals, or 145 cases, were selected at random. Of these 145 , over one half, or 87 , were forced to return to the agency within four to six weeks and were accepted then for federal clothing, federel surplus commodities, or W.P.A. certification. One hundred and ten of the families were visited. Of these, almost one half, or 42 , had moved and could not be located. Of the 68 interviewed, 26 had secured odd jobs but were still in need, while only 23 hed jobs on which they could manage. Seventeen had been forced to move in with relatives and nine to double up with friends. Fifty-eight families of the sixty-eight suffered from lack of clothing, fifty-four from lack of food.

38. Ibid., pp. 54-55.

39. Hosch, Melville, Supporting Data to Budget Request for M.B.S.S.., June 14, 1939, Exhibit.II. 
Thirty-five had accumulated debts and an equal number had had to drop their insurance. Thirty-five families had had to reduce the number of meals taken each day. There were thirty-three families presenting obvious hoalth problems such as malnutrition, high blood pressure, paralysis, anemia, carcimoma and goiter. Sixty-eight of the one hundred and ten had appealed to other agencies in the city, as shown by Social Service Exchange cleerings.

Another barometer of the effect of the limited intake policy was found in a study of eviction notices from January to May 1939. In the three Magisterial Courts in Louisville:

2,562 forcible detainer writs were served

368 of these were executed by the Court

38 families were actually placed on the street

4 were evicted for other reasons than non-payment of rent

7 tenants were identified as former Bureau clients or applicants

9 were awaiting W.P.A. assignment

3 had been on W.F.A. but were temporarily unassigned.

"It is obvious from these figures that only a small number of eviction notices are actually executed with the result that the tenant is placed on the street. However, the circumstances surrounding these evictions indicate an extreme degree of humiliation and hardship for the families...... Occasionally the family situation has been so pitiful that the employoes in the Court have made up a 'pot' between them to help the family pay a month's rent elsewhere." 40

Among the cases cited, there was one of a family with ten children which had been evicted five times since July, 1934. Their only source of income was the man's W.F.A. wage of $\$ 4.80$. Obviously, a family of this size, dependent on W.P.A. earnings, is in need of supplementary aid from the Municipal Bureau. Another family, with seven children, had no rescurces except the man's W.F.A. wage.

40. Tbid., pp. 56-57. 
He was temporarily ill. Since he soon could be re-employed, the Bureau was not able to help. It was stated that there were problems of iliness as a result of long dependence on inadequate income.

The Board of Education of Louisville conducted a survey extending over the period from February 13 through February 28 , 1939. Representative schools were chosen from all parts of the city. Of the nineteen white schools studied, $16.3 \%$ of the children were found to be in "urgent need" of one or more of the following: food, clothing, shoes and stockings and health services. Of the six colored schools studied, $25.8 \%$ of the children showed similar 41 need. Only $41 \%$ of the needs of the white children were being met, while even less, 35\%, of those of the colored ohilaren were being cared for. The agencies giving aid were the Municipal Bureau, the City Health Department, the Family Service Organization, the Parent Teacher Association, and various civic organization. A study made by the Attendance Department of the Board of Education showed that during December, 1938 and January, February, 1939, a total of 18,000 school days were lost by white and negro children because of "poverty", which means that they lacked clothes and shoes. A study made by the League of Nomen Voters in December, 1939, revealed that 1,339 school children had missed school for lack of food and clothing during a five month period the preceding term. The League estimated that an equal number of families and individuals had no income; that 6,282 families and individuals

41. City of Louisville, Board of Education, Study of Relief Needs in Louisville Public Schools, Harch $27,1939, p \cdot 3 . \ldots \ldots \ldots$ 42. Hosch, Supporting Data to Budget Request for M.B.S.S., p. 6. 
had less than $\$ 400$ a year, or $\$ 33$ per month; and that from 2,500 to 3,000 persons were in need of relief and not receiving help in December, 1938. 43

In March, 1940, a study was undertaken of the families refused assistance at the Municipal Bureau during November and December, 1939. The Council of Social Agencies, the local chapter of the American Association of Social Workers and the Graduate Division of the Social Administration of the University of Louisville cooperated in the study. A random sample of one hundred cases, representing one seventh of the total rejections, was studied by social workers who volunteered to assist.

Of the one hundred families, fifty-nine had applied for W.P.A. certification, one for C.C.C., and seven for N.Y.A. Sixteen had asked for direct relief. Another sixteen families were on W.P.A. and wanted additional help with food, coal, or clothing. One person requested admittance to the Home for the Aged and Infirm. 44

A minimum standard budget was worked out for each family. This was based on the budget used by the Jefferson County Aid to Dependent Children Department, using current retail prices in Louisville. Adequate information of current (March) family income was obtained for seventy-three of the one hundred families. Of these, fifty-eight were found to have incomes below the minimum standard budget. The distribution was:

43. League of Women Voters, Study of Relief Needs in the City of

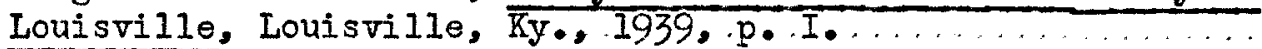

44. Blakey, Lois and McNeil, Elaine Ogden, Study of 100 Cases hose Applications for Assistance Were Rejected by The Louisville... Municipal Bureau of Social Service During The llonths of November and December, 1939, May 14, 1940, p. 5 . 


$\begin{array}{cr}\text { Percentage Deficit } & \text { Number of } \\ 0.1-25 \% & 18 \\ 25.1-50 & \frac{14}{\nu_{4}} \\ 50.1-75 & \frac{12}{58} \\ 75.1=100 & \frac{10}{5}\end{array}$

Eleven families were found to show definite evidence of suffering from lack of food. In five cases this was so severe as to have already been diagnosed as malnutrition by doctors.

The need of these families was demonstrated further by their housing. Of the one hundred femilies, twenty-nine had moved during the three months between the date of application and the time of investigation. Of these twenty-nine removals, ten were the result of evictions. At the time of the visit, five more evictions were threatened. Ten families had sought cheaper rent and six families 46 had left town, hoping to find work elsewhere. There were twelve cases illustrating that many of the families were forced to sell their household possessions, one by one, in order to live. In seventeen instances families moved in with relatives, in five cases with friends. In seren cases this doubling up meant that the two families were living on a relief allowance intended only for the one family. It was not possible to study the homes in which the families once lived; however, from their wages during their last period of regular employment, it seemed logical to assume that they represented a fair cross section of the population. At the time of investigation, however, they lived in very cheap quarters. In the seventy-six cases for which information was obtained:

45. Ibid., p. 22. 46. Ibid., p. 16. 
5 lived in homes renting for over $\$ 5.00$ a week

12 paid between $\$ 3.00$ and $\$ 4.50$ per week

30 paid between $\$ 2.00$ and $\$ 3.00$ per week

25 paid between $\$ 1.00$ and $\$ 2.00$ per week

4 paid under $\$ 1.00$ per week. 47

Yet, although these rents are very low, forty-five per cent of the families were in arrears with their payments. On the whole, it seemed that the lower the rent, the higher the rent debt. Because of the widespread terror of evictions, because families will sacrifice other necessities in order to pay rent, these figures are extremely interesting. They indicate the extreme pressure which financial need was exerting on the families.

There were eighty-four families for which information on the adequacy of clothing was obtained. Of these, forty-five reported their clothing was inadequate for work, twenty-eight said they had not enough clothing to enable all the children to attend school; and forty-six could not go to church. The eighty-one children of school age in the group of one hundred families reported a total of 666 days of absence from school. Sixty-five per cent of these absences were explained on the basis of lack of food, clothes and shoes; while twenty-seren per cent were due to sickness, colds or acoidents. There were four verified instances of children with desire and intellectual ability who were forced to 48

drop out of school because of economic pressure.

The one hundred families were classified according to the type of adjustment they were making at the time of the visit in March, 1940. There were sixteen families who seemed to be 
managing satisfactorily. By this was meant that the applicant's immediate needs were being met with no imminent threat of disaster. It included some families receiving W.P.A. wages. In only seven of the sixteen families was the adjustment made solely through currently earned income. There were only three families managing adequately on the earnings of one wage earner. No family with more than four members was able to manage on current earned income. No unskilled persons were able to manage without supplementary 49 income.

There were twenty-six families, or over one-fourth of the entire group, in serious noed in Narch, 1940. This group included "anyone who did not have regular food daily, shelter without threat of eviction, a place to sleep, or clothing sufficient to protect him from the elements." In four of these families there was no income whatever and the family was begging and searching garbage pails. There seemed indication that the families in this group tended to have fewer wage earners. These were chiefly untrained and tended to be younger than the group as a whole. In thirty-eight cases the income was below the minimum standard budget but subsistence needs were being met. In six cases the income covered the budget only by means of an unwise adjustment. For example, one woman earned a fairly adequate wage by sorting rags, but, because she had arrested tuberculosis and was forced to leave her children unsupervised, other arrangements would have been more desirable. There were fourteen cases in 
which there was not sufficient information to justify classifica51 tion.

The conclusion drawn from this study was that the foremost need was for more money for relief, since lack of funds had made necessary a policy excluding some groups from all assistance and since the assistance which was given was not sufficient to maintain a minimum standard of living.

Sketchy as this material is, it does provide an indication of the conditions in the city during the past two years, for which we have documentery evidence. By looking at statistics on the amount of the relief grants in relation to living costs, we cannot but realize that relief has been completely inadequate. Consideration of what this means to the individual family in terms of having to live without the necessities of life makes us realize the toll which is being taken. Those persons who were assisted by the Bureau were living on an only slightly more adequate scale than those excluded by the rigid intake policy. They were living without the common decencies of life.

The community cannot, by refusing to face the issue squarely, avoid the cost. The miracle is that these families have not lost all faith in the democratic way of life. 
III. REJECTED CASES, NOVEMBER AND DECEMBER, 1940. 


\section{REJECTED CASES, NOVEMBER AND DECEVBER, 1940}

The month of November, 1940 brought significant changes in the intake policy of the Municipal Bureau of Social Service. Since the first of that month, acceptance or rejection has been based on need alone, without reference to category. This means that all persons, employable or unemployable, old or young, became eljgible for assistance if their need was sufficient.

The interviewers in the Intake Department determined need for relief on the basis of a budget set up to include the actual rent paid by the family; one half ton of coal or $\$ 2.85$ a month for one or two persons, and one ton or $\$ 5.05$ for three or more, guided by qualifying conditions in the home. The food budget used was as follows :

\section{Size of Family}

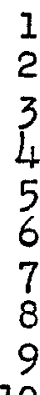

Monthly Food Allowance*

$\$ 6.00$

9.25

11.85

14.30

17.50

21.35

23.70

26.00

28.00

30.20

For each additional person over ten, two dollars a month was added. No other items were included in the budget except in cases for which doctors had recommended special diets.

Table XIV shows the situation of the families assisted

* The Superintendent of the Bureau estimates that this budget covers about forty per cent of the minimum standard when all needs are included. Families receiving relief also receive food stamps. 
Table XIV 52

Direct Relief Case Load, September through December, 1940

September October Norember December

Total Family Cases

Total Individuals in Family Cases

Average Relief Grant

Per Family

Per Individual

Total Single Cases

Average Relief Grant

Per Single Case

All Cases, Average Relief

Per Case

Per Individual $\begin{array}{llll}606 & 664 & 759 & 828\end{array}$

$2,353 \quad 2,556 \quad 2,936 \quad 3,216$

$\$ 18.15 \quad \$ 18.74 \quad \$ 22.97 \quad \$ 23.82$

$\$ 4.67 \$ 4.86 \$ 5.94 \quad \$ 6.13$

$429 \quad 443 \quad 477 \quad 493$

$\$ 11.90 \$ 12.65 \$ 1.36 \$ 1_{1.90}$

$\$ 15.56 \quad \$ 16.30 \quad \$ 19.65 \quad \$ 20.49$

5.78 \% $6.02 \quad 7.11$ \$ 7.29

by the agency since September, 1940, Not only was the intake policy broadened in November but, as would be expected, relief expenditures increased. More persons were cared for on a more adequate scale. During these months many more persons were being accepted for assistance than were being refused.

September October Norember December

$\begin{array}{lrrrr}\text { Accepted } & 128 & 161 & 154 & 123 \\ \text { Rejected } & 120 & 89 & 99 & 96\end{array}$

Although the Bureau counted 195 rejected cases in the months under consideration, only 177 are included in the study. This discrepancy is due to the fact that the agency regarded as a new rejection the second and third rejections of each case, whereas in the study each case was counted only once regardless of the number of times the family applied. In addition, there were several families who did

52. City of Louisville, Municipal Bureau of Social Service, Monthly Statistical Reports, September through December, 1940. 
not seem to fit into the study. For example, one man was recorded as rejected for "loss of contact" but he had returned meanwhile and had been accepted by another interviewer.

A. General Description.

From day sheets kept by each interviewer in the Intake Department were obtained the names of the families and individuals refused direct relief during the period studied. Each record was read and the desired information recorded on Form A. In many cases it was not possible to obtain all the information in which we were interested. The interviewers went into the family situation only so far as was necessary in order to determine eligibility. Often a few facts were considered as a sufficient basis for rejection.

The question, what sort of people asked for help, is answered in a general way by the following tables. Of the 177 unduplicated cases, 64, or over 36 per cent were negro. Approximately 15 per cent of the population of the city is negro. Thus it is apparent that a disproportionate number find themselves in financial need. The study the previous year revealed approximately the same percentage.

Table XV shows the marital status as it was reported by the persons applying. For the white group, over one half were married couples; whereas less than five per cent were single. Over twenty per cent were either separated, divorced or deserted, 
Table XV

$\begin{array}{lrrr}\text { Marital Status } & \text { White } & \text { Negro } & \text { Total } \\ \text { Married Couple } & 59 & 19 & 78 \\ \text { Common-law Couple } & 5 & 3 & 3 \\ \text { Single } & 20 & 13 & 77 \\ \text { Separated } & 4 & & 33 \\ \text { Divorced } & 17 & 19 & 4 \\ \text { Deserted } & 8 & 4 & 36 \\ \text { Widow } & & 2 & 12 \\ \text { Widower } & & & 2 \\ \text { Separated Common-law } & 113 & 64 & 177 \\ \text { Total } & & & \end{array}$

while fifteen per cent were widows and seven per cent widowers. The negro group displays a markedly different pattern. Here, less than thirty per cent were married couples. There was an appreciably larger number of separated, divorced and deserted. Thirty per cent of the negros applying claimed to be widows. The cases showed a great preponderance of broken homes. The previous study of rejected families found the sane situation.

Table XVI

$\begin{array}{lrrr}\text { Length of Residence } & \text { White } & \text { Negro } & \text { Total } \\ \text { Less than six months } & 5 & 2 & 7 \\ \text { Six months to one year } & 3 & & 3 \\ \text { One to five years } & 11 & 5 & 16 \\ \text { Five to ten years } & 6 & 3 & 9 \\ \text { Ten to twenty years } & 12 & 10 & 22 \\ \text { Twenty years and over } & 51 & 27 & 78 \\ \text { Total } & 88 & 47 & 135 \\ \text { Unknown } & 25 & 17 & 42 \\ \text { Grand Total } & 113 & 64 & 177\end{array}$

54. Tbid., pp. 7-8. 
It has frequently been charged that, since there is practically no direct relief available elsewhere in the State the city is deluged with dependent families moving to Louisville in order to obtain help. We find that this is not true. There is abundant evidence that persons applying for help have lived in the city many years if not always. Of the one hundred families studied a year ago, only three had lived in Louisville less than a year, thirty-four had lived here fifteen years or more, while twenty-six additional were life-long residents. Over eighty per cent of the cases for whom information was given had lived here for five years or more. This percentage would undoubtedly have been higher if length of residence were known for all the families. The forty-two families listed as "unknown" in Table XVI were all residents of the city; hence, the table is weighted in favor of persons who have lived here a short time only.

There seems to be, among the adults in the families making application, a disproportionate number of older persons. For both groups, as a whole, there was a disproportionate number of females as compared with the general population, although the latest census shows more females than males in the city. Contrary to popular opinion, these rejected applicants for relief do not have abnormally large families. Table XVII shows the size of the white families, which averaged 3.46 persons. Although there were a few large families, the majority were quite sma11. Evidently there are other factors at work in causing dependency. The families receiving assistance were about the same 
Age, Sex and Race of All Individuals in The Families Whose Applications Were Rejected.

White

Negro

Total

\begin{tabular}{|c|c|c|c|c|}
\hline Age in Years & Male & Female & Male & Female \\
\hline Under 5 & 18 & 33 & 4 & 12 \\
\hline 5 to 10 & 21 & 26 & 11 & 12 \\
\hline 10 to 15 & 23 & 28 & 7 & 6 \\
\hline 15 to 20 & 21 & 28 & 6 & 11 \\
\hline 20 to 25 & 15 & 18 & 3 & 7 \\
\hline 25 to 30 & 10 & 4 & 5 & 4 \\
\hline 30 to 35 & 11 & 9 & 3 & 7 \\
\hline 35 to 40 & 5 & 13 & 4 & 5 \\
\hline 40 to 45 & 10 & 10 & 4 & 11 \\
\hline 45 to 50 & 11 & 12 & 1 & 3 \\
\hline 50 to 55 & 7 & 10 & 5 & 5 \\
\hline 55 to 60 & 8 & 9 & 2 & 5 \\
\hline 60 to 65 & II & 7 & 2 & 2 \\
\hline 65 to 70 & 3 & 6 & 4 & 6 \\
\hline 70 and over & 10 & 2 & 5 & 4 \\
\hline Unknown & 4 & 7 & $I$ & 1 \\
\hline Total & 188 & 222 & 77 & 101 \\
\hline
\end{tabular}


size, as were, also, those in the earlier study of rejections. This is even more striking among the colored group. All studies made in Louisville will refute the common belief that colored families are larger than white. This has been taken into consideration by the Louisville Municipal Housing Conmission which has planned and built smaller apartments in the colored than in the white low-rent housing projects. Table XIX gives the size of the negro families under consideration. The average is only 2.64 persons.

\section{B. Rejection Reasons.}

The Bureau classifies for purposes of tabulation all rejected cases into four groups; those refused because of adequate income, because of lack of agency funds, because of loss of contact or failure to complete application, and services not desired. Itemized reasons for rejection are included in the case record. The cases were reviewed with the Superintendent of the Bureau who aided in the present classification.

The 177 families fell into $\mathbb{1}_{4}$ categories according to the reason for their rejection. Over twenty per cent, or 37, were refused because the income in the home was too high to permit supplementation. An equal number failed to complete their applications. The next largest group, 31, was refused help because relatives could assist. Thirteen families had unexhausted credit resources. Ten families did not wish the service which the agency had to offer. In three cases it was discovered that the service was not needed. Eight families were referred to the W.P.A., nine to the Juvenile 


\section{Reas on for Rejection: White Families}

Number in Family Making Application

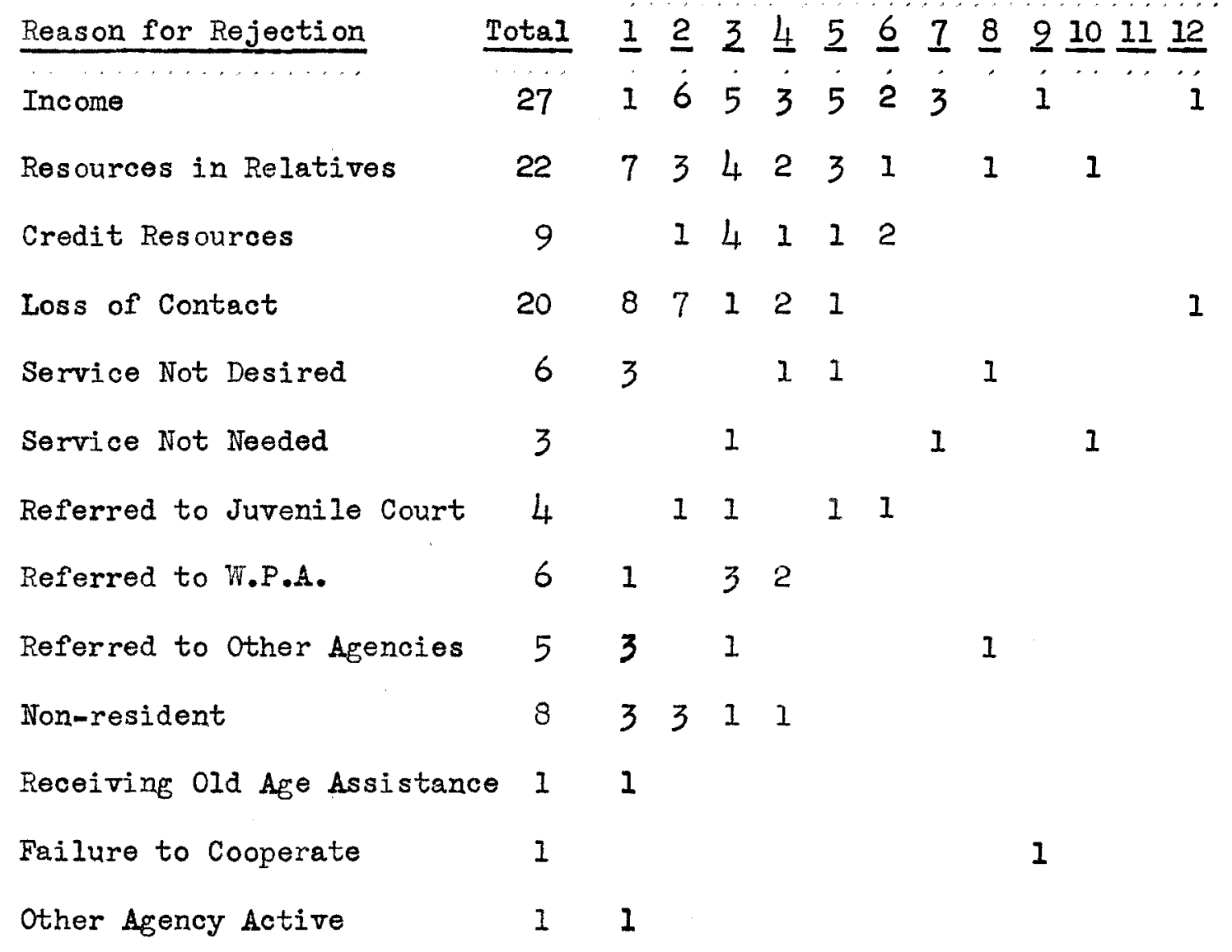

Total 
court and thirteen to various other sooial agencies. Four families had capital resources; one was ineligible because of income from another form of public assistance. One family failed "to cooperate." Another was already active with another social agency. Nine families were excluded because of lack of "legal settlement." The meaning of these reasons will be clarified by more detailed discussion of each group, broken down according to race.

Thirteon reasons for rejection appear among the 113 white cases. Twenty-seven were refused because of the income in the family; that is, the income was either more than the relief grant which would be allowed the family or else so close to it that supplementation did not seom justified. The adequacy of the incomes will be analysed subseguently.

Twenty-two of the white families were refused because they had relatives who were considered able to help them. In one family, consisting of a man and wife with five children in the home, The St. Vincent de Pau I Society telephoned; saying that they had been helping the family but could not oontinue to do so. One son, with only one dependent, a teacher in the public schools, had always helped the family in the past but could not support them. When the application made on December 23, the family was about to be evicted and the gas and lights were soon to be turned off. The man was not eligible for W.P.A., although he had lived in the city for thirty-six years, because he was not a citizen. He was soon to get his final papers. The son was asked to support the family until then. On Decomber 26, the son returned to the office 
saying he also helped his brother and could not support his father. However, he felt his father could manage by means of odd jobs until he received his final peipers. It is well to note that before the Intake Policy was brodened, the father would not have been considered eligible at all. As it was he asked to manage only temporarily until other resources opened up.

Another family was asked to remain separated, in relatires' homes. The man had been laid off the W.P.A. in August. The family had ma ged by sale of furniture and by help from relatives until foroed to break up their home. The man returned to his parents; the woman took the two children to her sister's home. When the man applied for help, he was to start back on the W.P.A. the next day. The agenoy explained that it could not supplement W.P.A. Wages and a sked that the relatives continue to help until he received a pay check.

There rere nine families asked to live on credit. This Ireans they were able to continue to live without paying rent and could obtain groceries on credit. For example, one married couple with an infant daughter had the man's widowed mother and younger sister in their home. His last work had been on December 1; he applied for help Decenber 2l. His rent had been due on December 1 but the landlord was not pressing for payment. Since he had not inguired about grocery credit or asked relatives to help, he was refused relief. The man had left the W.P.A. for private employment but the service station, in which he worked, was sold. The W.P.A. office reported that he would receive a work assignment on Deoember 23. 
He reapplied on December 27, because he had not received his W.P.A. assigament. As it was learned that he would do so in three or four days, the family was aga in rejected. On December 31, he reported that he had not been able to establish grocery credit, the gas and lights had been turned of $f$ and the family had no fuel. His wife, mother and sister had been ill. The family was then accepted.

The group termed "loss of contact" consists principally of persons who were asked to bring in additional information, necessary in determining eligibility, and who failed to do so. In a large number of the cases, relatives, who were asked to do so, failed to come into the office. The assumption made by the agency in these cases is that the family has been able to make other arrangements.

It is well to point out, however, that writers of the earlier study of rejeotions were particularly disturbed by this situation. About twenty-five per cent of those cases were rejected for this reason. The percentage for the total present group is just under twenty-one.

Of the six cases counted as "service not desired", three were instances of individuals for whom the only service available was the Home for the Aged and Infirm, which they did not want. One man was rejected because he refused to have a medical examination, which was suggested because he was also interested in W.P.A. and the latest doctor's statement stated he was not able to work. The fifth case was that of a middle-aged couple with three children. 
The man was going to the tuberculosis sanitarium. He had been running a restaurant, making about $\$ 100.00$ a month, and wanted help in planning for his family while he was hospitalized. The interviewer suggested that he could hire a man for $\$ 60.00$ a month to run the restaurant. His brother-in-law did the cooking in the restaurant, earned \$86.00 a month. A son by a former marriage, earning $\$ 36.00$ a month, was in the home. This would mean a monthly income of $\$ 76.00$. The man did not agree with this arrangement but said he could work out his own plans.

There were three cases in which the services of the agency were not needed. In one case, the man was in jail but it was believed that he would be released if he could return to work. His wife was confident his job had been held open so withdrew her application. In another case, the man asked for help while he was in the hospital for an operation but later learned that the cperation would not be necessary.

There were four cases of women, separated from their husbands, who were referred to the Juvenile Court for assistance in securing support; in the meantime they could live on credit or with relatives. The six W.P.A. referrals seem to be very closely allied with those asked to live on credit. Five of then were cases of persons not working for various reasons but still certified who were asked to manage until they were assigned. The sixth was referred to W.P.A. for investigation of eligibility for compensation for an injury.

Among the five families referred to other agenoies, two 
were referred to the Family Service Organizati on beca use it was believed that they were in need of social case work service. One boy of sixteen, a ward of the Kentucky Childrens' Home, was referred to the Travellers' Aid Society. One single man of fifty-seven, who could not explain how he had managed in the past and who had a work history of odd jobs and yard work, was referred to the Kentucky State Employment Service. This man had arthritis but was able to do moderately heavy work. He had lived with his father and brother until one died and the other moved out of town. He was living with a friend.

The eight families rejected as non-residents need little explanation. Although Kentucky has never had any settlement laws, it is generally accepted that residence is acguired by living in the State for one year and in axy particular locality for six months. The only service available to non-residents is return to the place of "legal settlement" and temporary assistance pending return. In these cases, this was not desired; there were no urgent needs. There was one case of a man eighty-three who was receiving $\$ 10.00$ a month from the 01d Age Assistance Depertrant. The Old Age Assistance law did not permit supplementation. Another family was rejected because of "failure to cooperate." This family consisted of a men, wife and seven children. He refused to talk with a former employer for whom he had worked seventeen years, who, a Ithough not promising a job, said he would like to see the man. Two days later the man returned, willing to talk with the employer. He learned, however, that there was no work available. As he was 
then about to be admitted to the hospital for an operation, the case was accepted. One man, separated from his wife and daughter, was rejected because a nother agency was active. He had temporary room and board with the Volupteers of America. It was suggested that he could remein there while he looked for work.

The sixty-four negro cases fell into ten different classes according to the reason for their rejection. Of these, ten were refused because of the family income. Nine had relatives who were able to help. One woman, separated from her husband, had two children to support. An older daughter, not in the home, had recently obtained work. She promised to assist her mother but did not do so. The woman was told to urge her daughter to contribute. The only income in the home was 22.00 a month from a nother son's C.C.C. employment. The woman was in poor health but had no medical report. The current income was above the agency relief grant. In another case, a man of seventy-four supported himself and his incapacitated wife on $\$ 9.00$ a month 0ld Age Assistance and $\$ 6.50$ a month he made from "junking." A married son, on the W.P.A., gave $\$ 10.00$ a month in food stamps and ate his evening meal with them in return. This brought the family income above the relief grant. This son's wife was in the tuberculosis sanitorium. He was anxious to maintain his own home in the event his wife should be released. Neanwhile he had his own living expenses and clothing to buy for his wife.

There were four negro families asked to live on credit until other resources materialized or until credit was exhausted. One family, composed of an incapacitated man, his vife, their 
Table XIX

\section{Reas on for Rejection: Negro Families}

Number in Family Making Application

Reason for Rejection

Income

Resources in Relatives

Credit Resources

Loss of Contact

Service Not Desired

Referred to Juvenile Court

Referred to W.P.A.

Referred to Other Agencies

Non-resident

Other Resources

Total
Total $1234567 \geq 9 \frac{10}{11} \frac{12}{1}$ $10 i 24$ i 1 1

9531

$4 \quad 211$

$\begin{array}{lllll}17 & 6 & 7 & 2 & 1\end{array}$

1

$4 \quad 4$

$\begin{array}{llllll}5 & 1 & 1 & 1 & 1 & 1\end{array}$

211

$\begin{array}{llllll}8 & 3 & 1 & 2 & 1 & 1\end{array}$

11

$421 \quad 1$

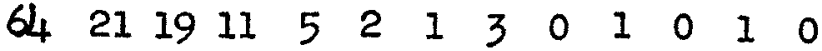


daughter and the latter's illegitimate son, ap plied on November 18 after the wife had been laid off the W.P.A. on October 11. She was eligible for immediate reassignment, therefore asked to manage a few more weeks. In a nother case, the American Red Cross telephoned that the man, with a wife and two children, was in the hospital for an operation and would be there for a month or more. The interviewer telephoned the grocer, who agreed to extend credit for two weeks. The refusal was considered to be temporary, pending the receipt of a medical report on the man. Nine days later, the woman reapplied. Since the rent was due and the grocer would extend no more credit, the case was accepted.

The proportion of families falline into the "loss of contact" category is larger among the colored than among the wite. Here it is twenty-seven per cent of the total.

Of the four negro cases rejected because the service of the agency was not desired, one withdrew the application, another did not wish to enter the Home for the Aged and Infirm. One vomen of sixtyfive, whose age could not be proven, preferred making her own plans to submitting to a medical examination. She had a growth on her hand which interfered with her employment as a laundress.

In five instances, negro women were referred to the Juvenile Court for assistance in securing support from their husbands. One case in this group was that of a pregnant woman with eight children, the oldest a fourteen year old daughter. The husband was earning twenty dollars a week. He contributed six to ten dollars a week according to his earnings. The rent was three months in arrears and 
an eviction was threatened. The interviewer telephoned the Juvenile Court, who said they could arrange for the man to prevent the eviction. The woman wished to make a formal filing so that his support would be more regular. She planned to ask for $\$ 10.00$ a week. The agency relief grant would have been $\$ 2.55$ a month.

One man, with six dependents, was referred to the W.P.A. to discuss with them his discharge as an "unsatisfactory worker." Pending reassignment, it was assumed he could live on credit, having received a pay of eighteen dollars five days previously. Two weeks later a City Hea Ith Nurse telephoned that the man ill and the family in need. The case was then accepted. In the other case of referral to W.P.A., the man was referred to investigate compensation for an injury.

Among the "referrals to other agencies", there was a man sent to the Urgan League for assistance in finding work and to the Rehabilitation Office for retraining. Although only twenty-nine, he could not do manual labor because of osteomyelitis. Fe and his wife and child were living in his mother's home. The income there was sufficient for subsistence needs. The maj ority of the other cases were referred to the Kentucky State Employment Service for help in obtaining employment.

There was only one family in which the primary reason for rejection seemed to be the fact that it was "non-resident." In four cases, the refusal was based on what might be called capital resources. One widower, with no children, a week before his application as compensation for a broken leg had recoived 125.00 . 
Another widower had a second-hand store from which he could not earn a living but which valued at $\$ 250.00$. Both of the other cases had received sums of money as compensation for injuries. Physical surroundings in the intake department are unattractive. Agency efforts to obtain better facilities have not been effective. The egency has had to feel its way. Funds, even though increased for 1941, were far under the amount required to meet all cases in which additional income was necessary for subsistence needs. In order to keep within the agency budget, clients were asked to utilize every possible resource and credit whener it did not too heavily indebt them. Aware of the lack of agency funds, the interviewers find it difficult at times to have the clients realize why they are rejected. Some clients seemed confused. There is evidence that the interviewers are cognizant of the need of keeping down the case load. They are aware of the danger of trying to prove clients ineligible. The experience of being rejected for relief can be a constructive one for the client in helping him to organize his resources. The professional quality of the service rendered by the intervievers is emphasized by the fact that there is no indication of self interest on thejr part or of rejection of clients because of personal antagonism. There is a conscientiousness and intensity in their work and undoubted integrity in their service to the public.

\section{Family Neod.}

As indications of the need of the family for assistance at the time of rejection minimum standard budgets were computed for 
each case. These budgets were based on the standerd set up by the Works Projects Administration in Kentucky in Cctober, 1940. No provision was made for carfare, recreation, school supplies, or church; all items commonly accepted as essential. Food, rent, coal, gas and lights, olothing, household supplies, medical supplies a d insurance were estimated on an emergency maintenance level. The actual figures used are given in the Appendix.

The minimum budgets estimated for each family were intended only as an approximation of noeds. The rent allowance seemed high compared with actual rentals but even 80 was not sufficient to insure sefe, decent or sanitary housing. The rejection study of the previous year utilized the budget computed by the Jefferson County Aid to Dependent Children Department. Comparison with that budget on the basis of a man, wife, daughter nine and son four shows the present one to be more generous.

\section{$\frac{\text { Minimum Weekly Standard Budget for Family of Four }}{55}$}

$$
\text { A.D.C. Budget Present Budget }
$$

Rent

Food

Clothing

Fuel and utilities

Household

Health and medical care

Education

Reoreation

Insurance

$$
\begin{array}{r}
\$ 1.86 \\
6.43 \\
2.68 \\
.69 \\
1.46 \\
.18 \\
.05 \\
.23
\end{array}
$$

$\$ 12.58$
$\$ 3.05$

55. Ibid., p. 10. 
of the 140 families whose incomes were known and compared with the minimum standar budget set up individually for each family, over one half, or 71 , had less than twenty per cent of the budget at the time of rejection. Only fourteen had enough to enable them to live on an emergency level. Twenty-five had as much as twenty per cent but less than fifty per cont, while an additional fifteen had incomes insufficient to cover seventy-five per cent of their basic needs. It is evident that there can be no doubt of the financial need existing in these families. Although only thirtyseven of the families were rejected because their financial need was not considered great enough to justify public assistance, it is apparent that the intake policy of the agency still restrictive. There were many urgent human needs unmet. Few, if any, of the clients were aot convinced that help was imperative. Many times the caseworkers recognized this need but the families could not be considered eligible because of the restrictive policy.

Breaking down totals according to major reasons for rojection and the percentage of the budget covered by the family income, there seem to be significant variations. Among the twentyseven white families refused relief because of the income in the home, only seven had, at the time of rejection, as much as or more than the budget. Of the remaining, sixteen $f a r$ whom information was given, only two had as much as eighty per cent of the minimu, while nine had less than sixty per cent. For the family which seemed most in need the sole income was a son's C.C.C. earnings of $\$ 22.00$ a month and food stamps of $\$ 12.00$ a month. The family was living in a 
condemned house and so paid no rent. The husband, aged forty-one, was awaiting W.P.A. assigment as a clerk. His epileptic wife was not able to work. There were four children in the hame besides the boy in the C.C.C. Another family, of twelve, was dependent on the eighteen year old daughter's earnings of $\$ 56.30$ a month. An older son was certified for N.Y.A. but not assigned. The father was forced to leave the W.P.A. because of sacro-illiac strain which necessitated an operation before he could aga in work.

Table XX

White Families Rejected because of Income in the Home; Percentage of Budget Covered by Income.

Number in

Family Group
Total Under 20-30-40-50-60-70-80-90- 100 Unknown

$\begin{array}{llllllllll}20 & 29 & 39 & 49 & 59 & 69 & 79 & 89 & 99 & \text { and }\end{array}$
1

2

3

4

5

6

7

8

9

10

11

12

Total

1

27
1

6

4

3

5

2

3

2

1

11
1

$2 \quad 1 \quad 3$

121

11

21

1

2
1

2

\footnotetext{
Note: One family of nine, "income unknown", was counted as a family
} of three in Table XVIII. 
The ten negro families, rejected on the basis of sufficient income, show greater neod. None of them had as much as the minimum budget; five had less than sixty per cent. Whereas none of the white families had less than thirty per cent of the budget, two of the negro families did. In one of these, the father was not able to work because of ulcers. The incone for this family of five was twenty-four dollars a month. The interviewer estimated that the relief budget would be $\$ 31.50$. The mother earned $\$ 3.00$ a week as a domestic. The regular wage earner, a s on of twenty-four, had been ill. There were two younger children, one of whom picked up two or three dollars weekly through odd jobs. Since the son would soon be reassigned to the W.P.A., the family was asked to manage until then. Another family, whose incme covered forty-five per cont of the budget, had two wage earners. The man earned $\$ 10.00$ a week and the woman $\$ 5.00$. There were nine children in the home, the oldest a girl of eighteen, none of whom had ever worked. The family had an eviction notice which was supposed to have expired two days before the date of application.

As would be expected, the families who were refused because of resources in relatives hed fewer resources of their own. Of the nineteen white families in this group for whom information was given, thirteen had less than twenty per cent of the budget. One woman, aged forty-three, had no income whatever. She had separ at ed from her husband for twenty years. Her parents supported her until their death six years ago. Her daughter had supported her since then but had had to quit working because of the birth of 


\section{Negro Families Rejected because of Income in the Home, Percentage of Budget Covered by Income.}

Number in

Family

Group
Total

\section{1}

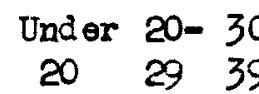

$30-40$ 3949

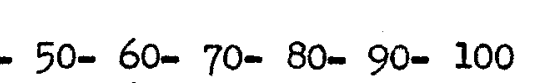
over

Unknown

1

2

3

4

5

6

7

8

9

10

11

Tota

\section{1}

2

3

1

1

1

1

1
1

1

1
1

1

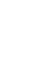

Note: One family of four, "income unknown", counted as family of three in Table XX.

her ohild. The woman was referred to the City Health Department, which reported that she was physically able to work. In ten days nothing furthor was heard, so it was assumed thet she had secured employment. Nine days after that, she reapplied, but was refused on the basis that she could look further for a job. She had never worked. In a nother family, conposed of a man, wife and eight children, the only income was $\$ 22.60$ a month. A son, not in the hame, earned 
White Fomilies Rejected Because of Resouroes in Relatives; Percentage of Budget Covered by Income.

Number in

Family Total Under 20-30-40-50-60-70-80-90-100- Unknown $\begin{array}{llllllllll}\text { Group } & 20 & 29 & 39 & 49 & 59 & 69 & 79 & 89 & 99\end{array}$

1 33

$2 \quad 4 \quad 3$

1

3

52

1

2

422

53

1

1

$6 \quad 1 \quad 1$

7

1

8

1

1

9

1

$I$

10

11

1

1

$\begin{array}{lllllllll}\text { Total } & 22 & 13 & 1 & 1 & 1 & 1 & 2 & 3\end{array}$

$\$ 54.00$ a month and contributed $\$ 2.00$ of that to his parents. The oldest daughter earned $\$ 2.00$ a weok through housework. A friend paid the rent. It was suggested that the son could move into the home. The man was physically unable to work.

The situation among the negro families, refused because of resources in relatives, does not seem to show so much need. Part of this is due to the fact that when relatives were already assisting, the amount of that assistance was included in the family income. There seem to be more instances, among the negroes, of relatives 
helping at the time of application. The only case of a family with less than twenty per cent of the budget, was a man, aged 40, who applied for help December 2. He had been laid off the W.P.A. on November 19, because he had not been able to do the work. He did not have to pay rent, his niece, living next door, could help. There was a possibility of his being assigned to a light work project. In another family the income was well over the budget amount. A woman, aged seventy, had worked as a domestic at the same place from 1915 to May, 1940. She had rhoumatism and did not feel woll enough to work. She was living in her daughter's home. This daughter earned $\$ 34.00$ a month as a domestic, wile her husband earned 12.00 a week. They had only one child.

Table XXIII

Negro Families Rejected Because of Resources in Relatives; Percentage of Budget Covered by Income.

Number in

Family Total Under 20-30-40-50-60-70-80-90- 100 Unknown $\begin{array}{lllllllllll}\text { Group } & 20 & 29 & 39 & 49 & 59 & 69 & 79 & 89 & 99 & \text { and }\end{array}$ over

\begin{tabular}{|c|c|c|c|c|c|c|c|}
\hline 1 & 1 & 1 & & & & & \\
\hline 2 & 2 & & & & 1 & & 1 \\
\hline 3 & & & & & & & \\
\hline 4 & 4 & & & 1 & & 2 & 1 \\
\hline 5 & 2 & & 1 & & 1 & & \\
\hline tal & 9 & 1 & 1 & 1 & 2 & 2 & 2 \\
\hline
\end{tabular}

The fomilies refused for all of the other reasons show very striking inadequacies. Of the forty-eight whose income was knowr, only eight had as much as forty per cent of the budget, while thirty-two had less then twenty per cent. 
The situation among the negro group is similar. Here, five out of thirty-five had as much as forty per cent, while twenty-two had less than twenty per cent.

Table XXIV

White Families Rejected for All Other Reasons, Except "Nonresident" and "Other Agenoy Active"; Percentage of Budget Covered by Income.

Number in

Family Total Under 20-30-40-50-60-70-80-90-100 Unknown Group

$\begin{array}{llllllllll}20 & 29 & 39 & 49 & 59 & 69 & 79 & 89 & 99 & \text { and }\end{array}$ over

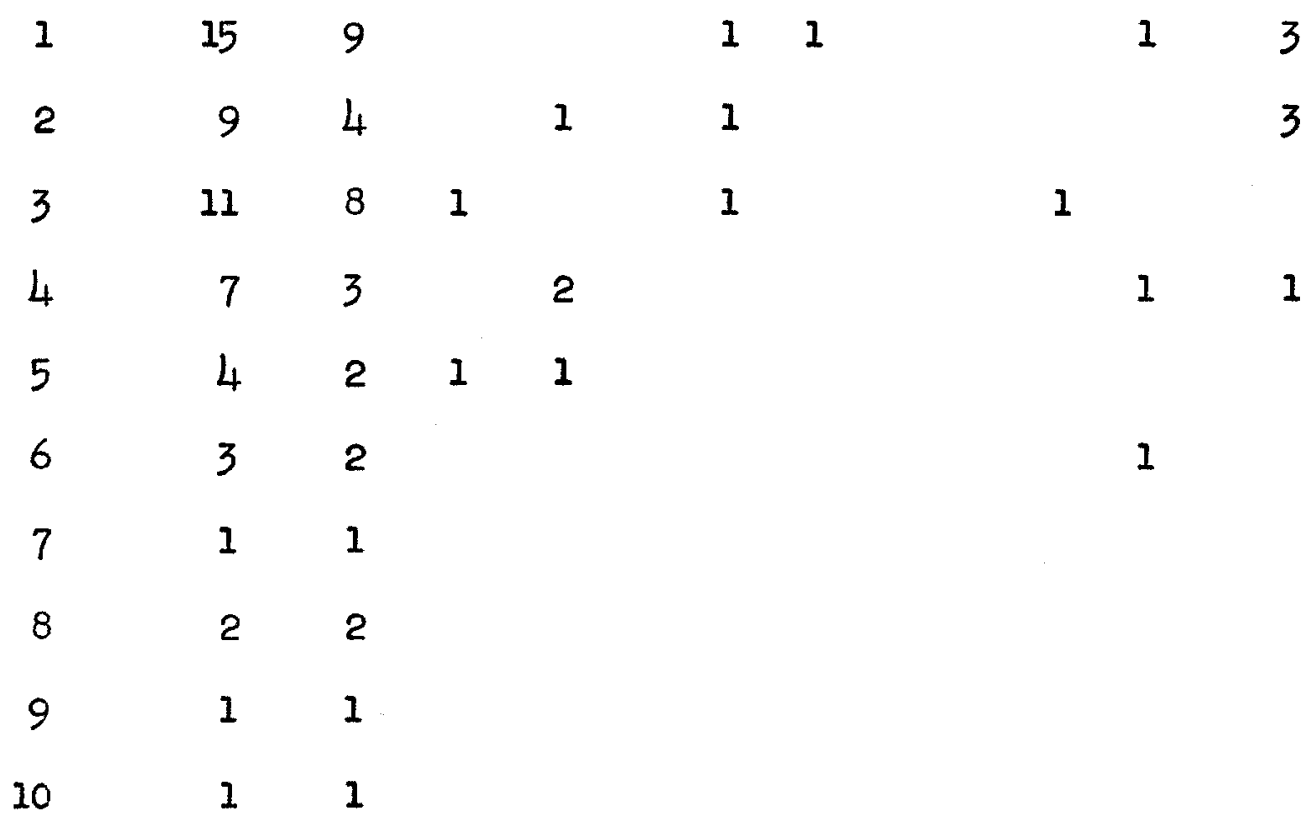

11

$12 \quad 1 \quad 1$

$\begin{array}{llllllllll}\text { Total } & 55 & 34 & 2 & 4 & 3 & 1 & 1 & 3 & 7\end{array}$

Note: Discrepancies in size of family as shown in this table and Table XVIII are due to the fact that the latter included only members of the immediate femily while Table XXIV includes all members of the household. 
Negro Families Rejeoted for All Other Reasons Except "Other Resources" and "Non-resident"; Fercentage of Budget Cover ed by Income.

Number in

Family Total Under 20-30-40-50-60-70-80-90-100 Unknown Group $\begin{array}{llllllllll}20 & 29 & 39 & 49 & 59 & 69 & 79 & 89 & 99 & \text { and } \\ \text { over }\end{array}$

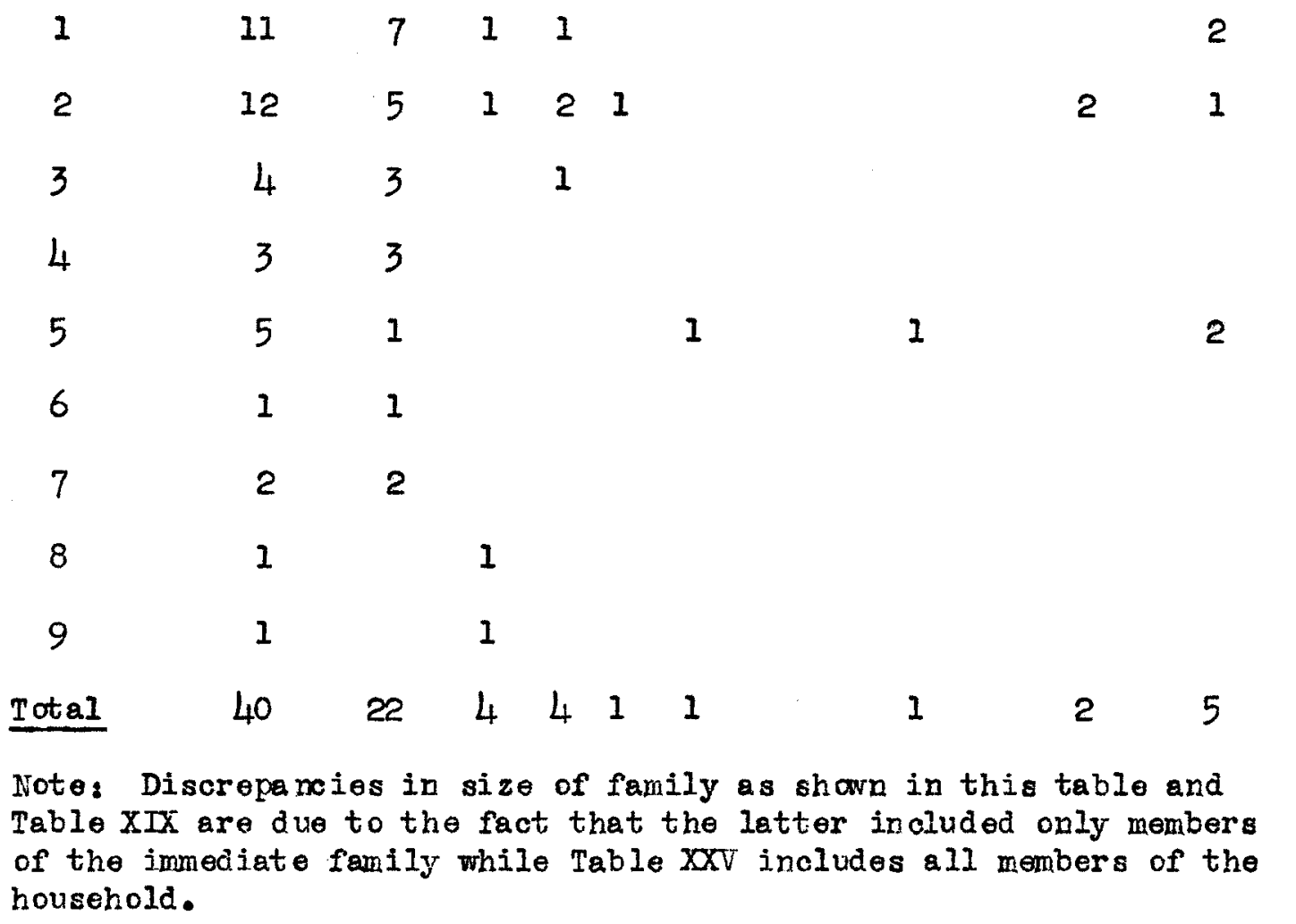

There is feeling in the community that people applying for relief have been known to many agencies for many years. of the 177 families, 75 had nover been assisted by the public agency in the pest. For 23 the asking for any kind of help was a new experience. Thus, very many families were totally unaccustomed to dependency. The large number of families returning after the fir st rejection only to be refused again, indicates possible misunderstanding on the part of the client of the position of the agency. The families, 
Table XXVI

\section{White Cases}

Known to Social Service Exchage

Unknown to Social Service Exchange

Rejected twice in Nove and Dec.

Rejected over twioe in Nov and Dec.

Rejected again from Jan.1 - March 17.

Accepted in November or December

Accepted from Jan.1 through March 17

Active on Wiar oh 17

Accept ed by Other Agencies
Total old New Recurrent

$\begin{array}{llll}97 & 48 & 34 & 15\end{array}$

$\begin{array}{llll}11 & 5 & 1 & 5\end{array}$

$\begin{array}{llll}4 & 2 & 1 & 1\end{array}$

$\begin{array}{llll}12 & 6 & 2 & 4\end{array}$

$20 \quad 13 \quad 3 \quad 4$

$\begin{array}{llll}18 & 9 & 2 & 7\end{array}$

$\begin{array}{llll}24 & 13 & 3 & 8\end{array}$

$\begin{array}{llll}31 & 13 & 4\end{array}$

Table XXVII

Negro Cases

Know to Social. Service Exchange

Unknown to Social Service Exchange

Rejected twice in Nov, and Dec.

Rejected over twice in Nov and Dec.

Rejected again from Jan.1 - Harch 17

Acoepted in November or December

Accepted from Januery 1 through Naroh 1711

Active on Narch 17

Accepted by Other Agencies
Total Old New Recurrent

$\begin{array}{llll}51 & 25 & 18 & 8\end{array}$

$13 \quad 1 \quad 12$

642

121

32

$\begin{array}{lll}4 & 3 & 2 \\ 3 & 5 & 3 \\ 5 & 6 & 5\end{array}$

$\begin{array}{llll}8 & 3 & 4 & 1\end{array}$

aware of their own need, find it hard to accept the fact that the agency cannot help them. Thirty-eight white and twenty colored cases were subsequently accepted by the agency for various services. Perhaps further clarification of the situation often meant recognition of eligibility. It was often true that families were asked to try to work out their own arrangements in an effort to prevent premature giving of assistance. When these families found they could not, they were then accepted. The figures for the 
number accepted by other social agencies were obtai ned through Social Service Exchange clearings. Many of these were Iegal Aid Society and Juvenile Court registrations. The extent of the service rendered is unknown.

Table XXVIII

White Cases

Reason for Rejection

$$
\begin{aligned}
& \text { Income Resources Loss of credit } \quad 411 \\
& \text { in Contact Resources Other } \\
& \text { Relatives }
\end{aligned}
$$

Known to Social Service Exchange dy Unknown to Social Service Exchange 3

$\begin{array}{rr}21 & 17 \\ 1 & 3\end{array}$

9

Rejeoted twice in Nov and Dec. 4 Rejected over twice in Nov, and Dec. I Rejected again from Jan.1- harch 173

Accepted in November or December 3 Accepted from January 1 - Warch 173 Active on March 17

$3 \quad 4$

Accepted by other agencies

5

$1 \quad 1$

Among the white families, a relatively larger number of those refused because of family income and because of resources in relatives returned again and again to the agency. This indicates persistent effort of the families to secure assistance when they found themselves unable to live on the inadequate resources which were the basis of their ineligibility. Since it is impossible for families to live on twenty to forty per cent of a subsistence budget, many returns can be expected. Relatively, more of those rejected because of credit resources and various other reasons were subsequently accepted for help. That seven out of the nine families refused because of credit resourees were accepted by viarch 17, 1941, 
would seem very significant. Apperently these families were forcod to exhaust every possible resource. It is false logic for the community to consider that it is saving money by forcing the clients to go to such extremes. These persons were a burden to landlords, grocers and all creditors. The community was paying the bill by levying special assessments on this small group instead of spreading the burden more equitably.

Table $\operatorname{xxIX}$

Negro Cases

Reason for Rejection $\begin{aligned} \text { Income Resources Loss of Credit All } & \text { All } \\ \text { in } & \text { Contect Resources Other } \\ \text { Relatives } & \text { Reasons }\end{aligned}$

Known to Social Service Exchange 9 Unknown to Social Service Exchange 1 $\begin{array}{lll}7 & 13 & 4 \\ 2 & 4 & \end{array}$

18

Rejected twice in Nov and Dec. 2 Rejected over twice in Nov.and Dec. Rejected again from Jan.1-Nar on 171

Accepted in November or Decamber Accepted from January 1-likar ch 17 Active on March 17

$\begin{array}{lllll}4 & 1 & 5 & 1 & 3 \\ 3 & 1 & 4 & 1 & 2 \\ 1 & 1 & 2 & 1 & 3 \\ \text { families refused because of failure }\end{array}$
to complete their applications, nine, or over one-half, returned and were accepted within a few months. Of these nine, four had been asked to bring in relatives, four to bring additional information concerning residence, work history, resources, etc., and one family had not answered a letter inquiring about a son who was eligible for the C.C.C. The families were accepted when they returned to the agency 
with the requested information.

D. Family Resouroes.

In combating dependency, the principal resource of any family is the ability of one or more of its members to find gainful employment. Traditionally, it has been the function of the man to earn the family's bread. From a sooial point of view, this is sound, since it leaves the woman free to make a home and care for the children.

An anelysis of the following tables gives considerable insight into why the families under consideration were in their present plight. We see from Table XXX that, of the 120 white males sixteen years of age and over in the 113 households, almost one-half, or 55 , had never had a steady job. Although many of these were quite young, twenty-three were under twenty-five, an apreciable number had long since passed an age at which they might have expected to find steady work. Of the ninety-five for wh om the usual occupation was known, twenty-seven could be classified only as "odd jobs"; this included. "junking", "yard men" and all sorts of day work. An additional thirty-seven were unskilled laborers. Of all other occupations, only carpenters and peinters were represented to any appreciable extent.

Table XXXI classifies these same pasons according to their employability in terms of health. Of the 120 , at least 37 were definitely diagnosed by medicel a uthorities as being totally unable to work. Another 16 were capable of light or non-menual labor only. 
All White liales, Sixteen and Over, in Household, by Age and Occupation...

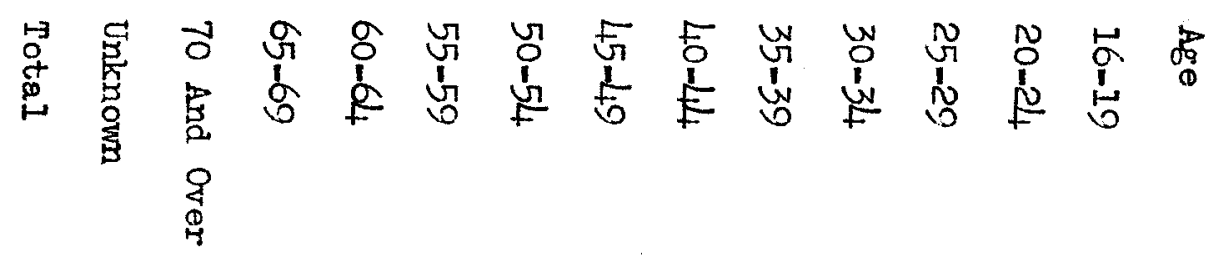

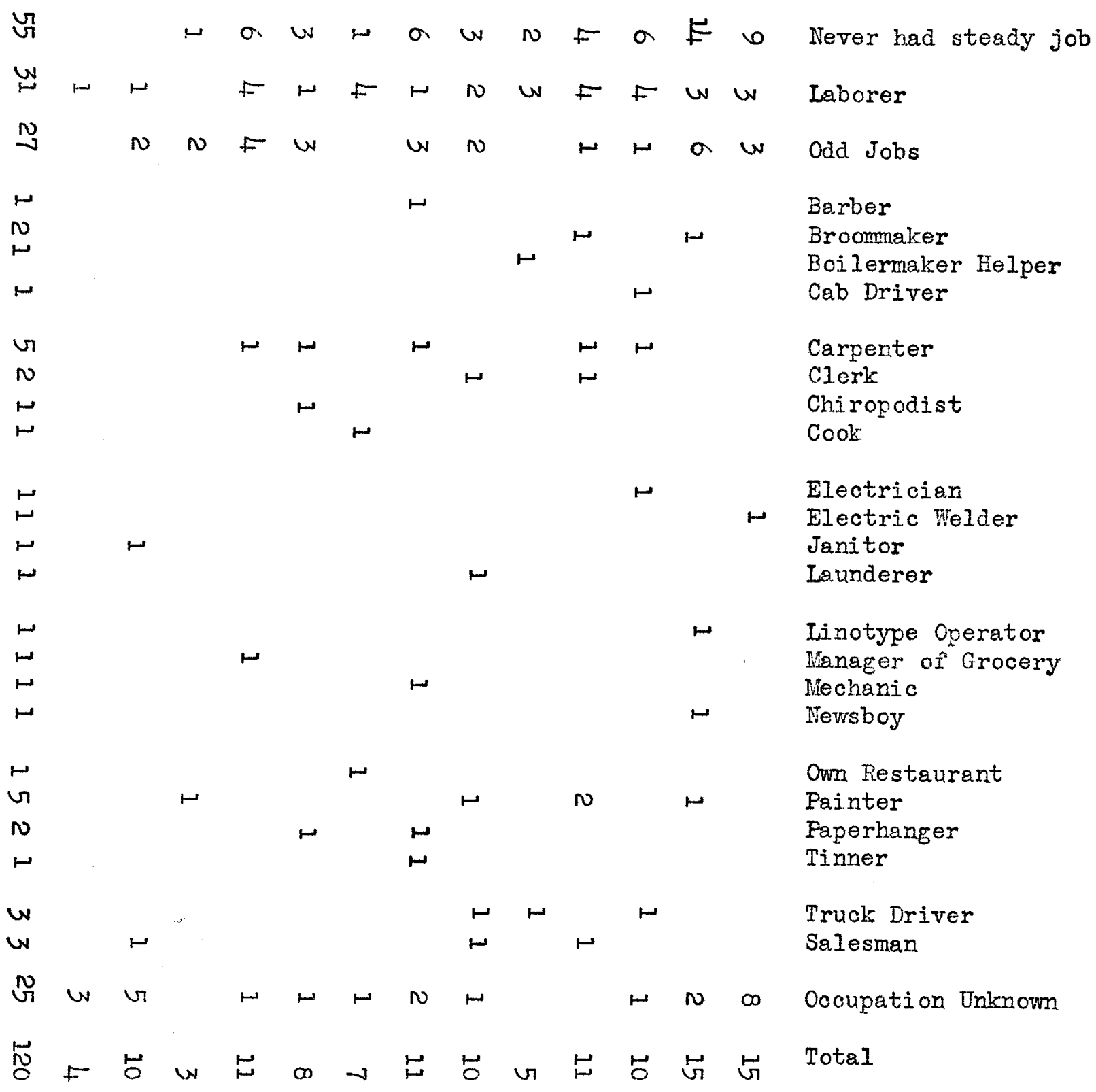


Table XXXI

Health of All White Males, Sixteen and Over, in the

Fouseholds.

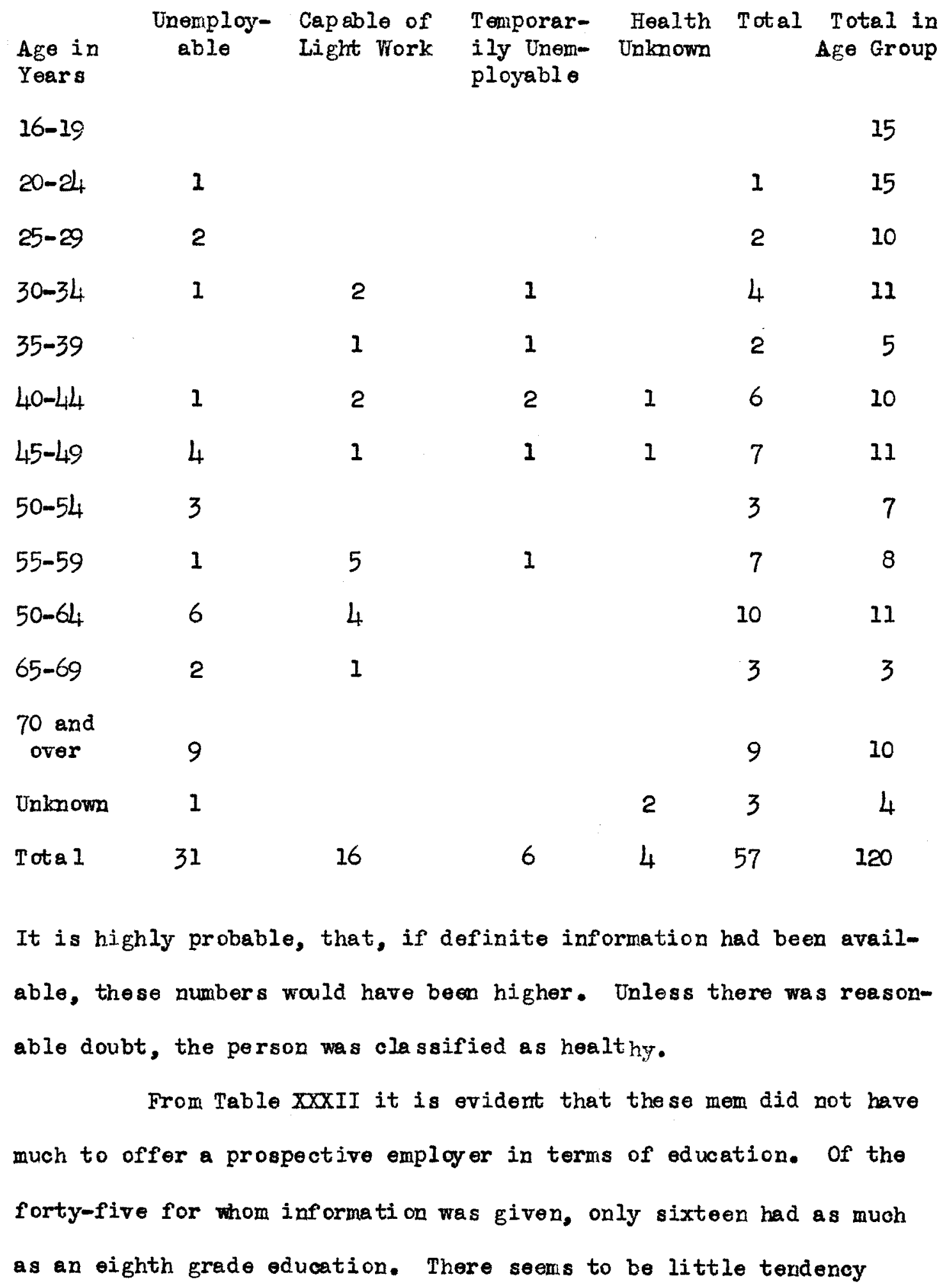


All Wite Males, Sixteen and Over, Classified by Age and Education.

Age in

Years

$16-19$

$20-24$

$25-29$

$30-34$

$35-39$

$40-44$

$45-49$

$50-54$

55-59

$60-64$

$65-69$

70 and

over

Unknown

Highest Grade Completed

$$
\begin{array}{llllllllllllll}
0 & 1 & 2 & 3 & 4 & 5 & 6 & 7 & 8 & 9 & 10 & 11 & 12 & \text { over Un- Total } \\
12 & \text { known }
\end{array}
$$

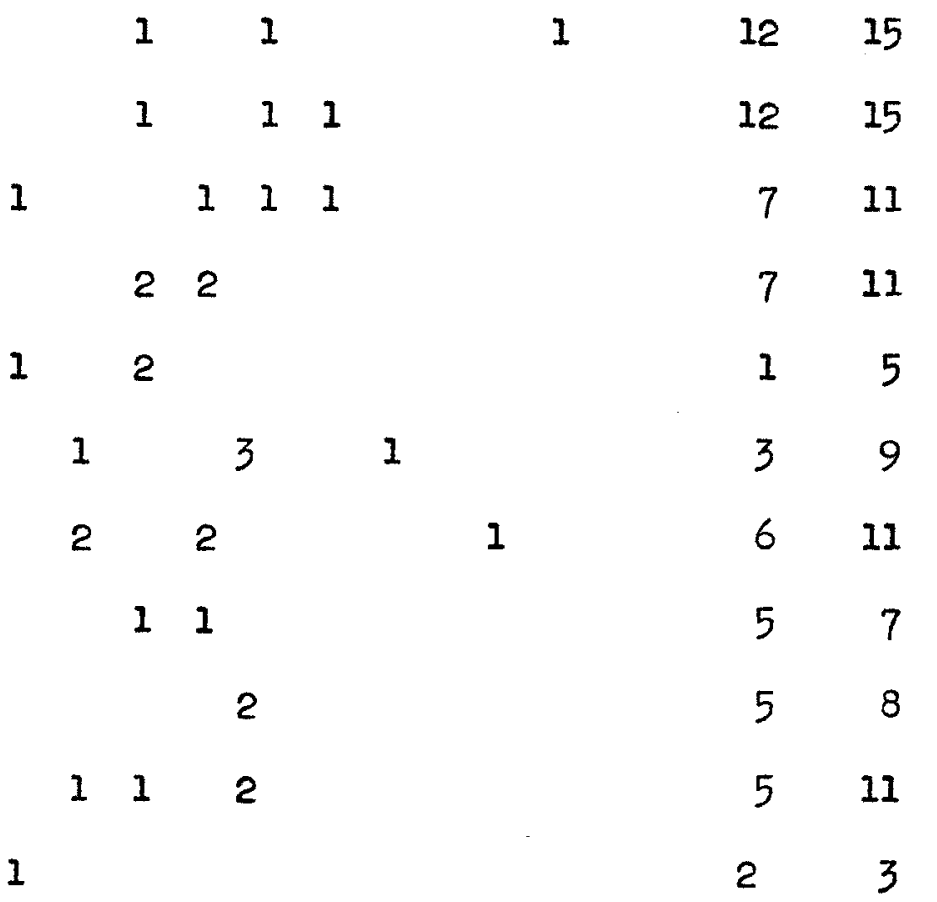

1

810

$4 \quad 4$

Tota 1

$\begin{array}{llllllll}2 & 1 & 2 & 1 & 3 & 4 & 8 & 6\end{array}$

$\begin{array}{lllll}11 & 2 & 1 & 1 & 1\end{array}$

$77 \quad 122$

for the younger group to have more education. This is not strange. One would expect young men with education to have jobs and hence not appear in the group under consideration. With so few cases, further generalizations are dangerous but there seems to be littb significant correlation between the group "never had a steady job" and those with lesser amounts of education. This indicates the significance of health as a factor determining ability to find 
All Negro Nales, Sixteen And Over, in The Household, by Age and Occupation.

Occupation

\begin{tabular}{|c|c|c|c|c|c|c|c|c|c|c|c|}
\hline $\begin{array}{l}\text { Age in } \\
\text { Years }\end{array}$ & 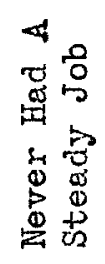 & 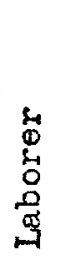 & $\begin{array}{l}0 \\
0 \\
0 \\
0 \\
\tilde{D} \\
\tilde{Z}\end{array}$ & 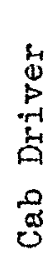 & 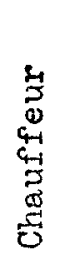 & $\begin{array}{l}E \\
\vdots \\
0 \\
0 \\
ن\end{array}$ & 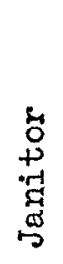 & 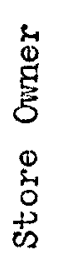 & 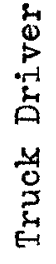 & 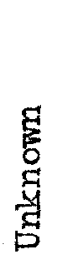 & 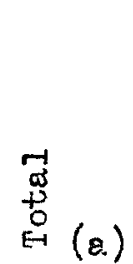 \\
\hline $16-19$ & 4 & 1 & 1 & & & & & & & 2 & 4 \\
\hline $20-2 u$ & 3 & 2 & 1 & & & & & & & & 3 \\
\hline $25-29$ & 3 & 2 & 2 & & & & 1 & & & & 5 \\
\hline $30-34$ & 1 & 3 & & & & & & & & & 3 \\
\hline $35-39$ & & 4 & & & & & & & & & 4 \\
\hline $40-44$ & 2 & 1 & 2 & 1 & & & & & & & 4 \\
\hline $45-49$ & 1 & & 1 & & & & & & & & 1 \\
\hline $50-54$ & & & 2 & & 1 & & 2 & & & & 5 \\
\hline $55-59$ & & & 1 & & & & 1 & & & & 2 \\
\hline $60-64$ & 2 & & 1 & & & & & 1 & & & 2 \\
\hline $65-69$ & 1 & & 1 & & & 1 & & & 1 & 1 & 4 \\
\hline $\begin{array}{l}70 \text { and } \\
\text { over }\end{array}$ & 2 & 1 & 2 & & & & & & & 2 & 5 \\
\hline Unknown & & & & & & & & & & 1 & 1 \\
\hline Total & 19 & 14 & 14 & 1 & 1 & 1 & 4 & 1 & 1 & 6 & 43 \\
\hline
\end{tabular}

(a) Does not include "Never Had A Steady Job." 
employment. Other factors, such as emotional ones, might be worthy of future study.

The group of negro males presents much the same picture. of the total of 43 males sixteen and over in the sixty-four families (notice that there were fewer men than families) nineteen had never had a steady job. Fourteen had no occupation other than odd jobs and another fourteen were unskilled laborers. Fifteen were completely unable to work, while ten had limited employability.

Table XXXIV

Health of All Negro Males, Sixteen and Over, in the Households Health Unemploy- Capable of Temporar- Unknown Total Total in Age in able Light Work ily Unemployable Age Group Years

$16-19$

$20-24_{4}$

1

1

2

3

$25-29$

2

1

3

5

$30-34$

1

1

3

35-39

1

1

4

40-44

2

2

4

45-49

1

1

1

$50-54$

1

3

45

55-59

1

1

2

2

$60-64$

2

2

2

$65-69$

2

2

4

4

70 and

over

Unknown

1

1

1

Total

14

10

1

3

38

43 
Table XXXV

\section{All Negro Males, Sixteen and Over, Classified by Age and Education}

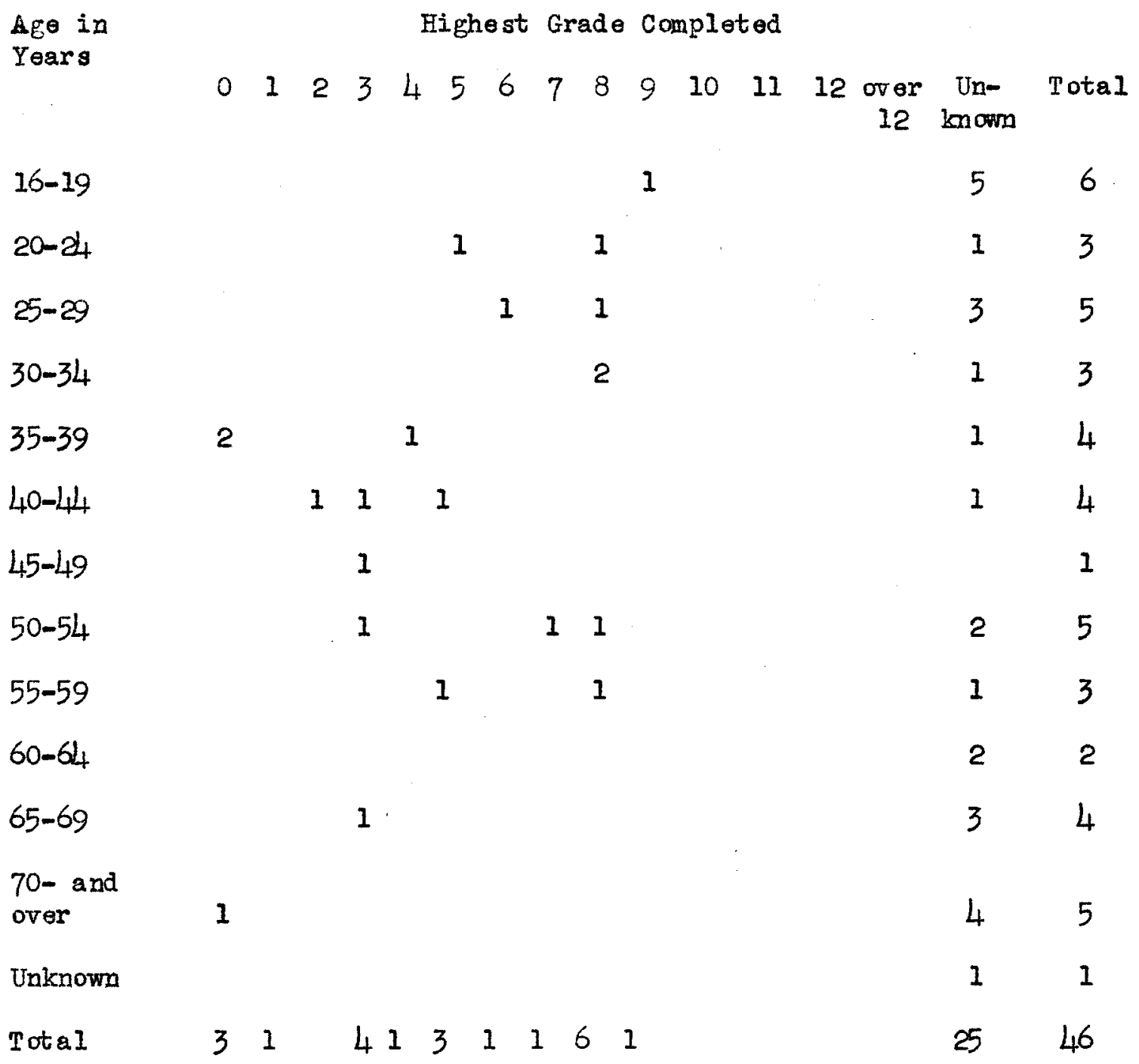

Inf ormation on education was given for only nineteen of the negro males. Of these, seven had completed the eighth grade, approximately the sane proportion as in the white graup.

For each family, one person was selected as being the most logical wage earnor. If there were no employable members, the male head of the family was chosen, even though he could not work. When the man was unemployable but had a wife or child able to 
Male, White Wage Earners; by Age, Occupation and Health. (Includes heads of families only.)

Occupation 20- 25- 30- 35- 40- 45-50-55-60-65-70 Un- Total 24. $2934 \quad 39 \quad 44 \quad 49 \quad 54 \quad 59 \quad 64 \quad 69$ and known over

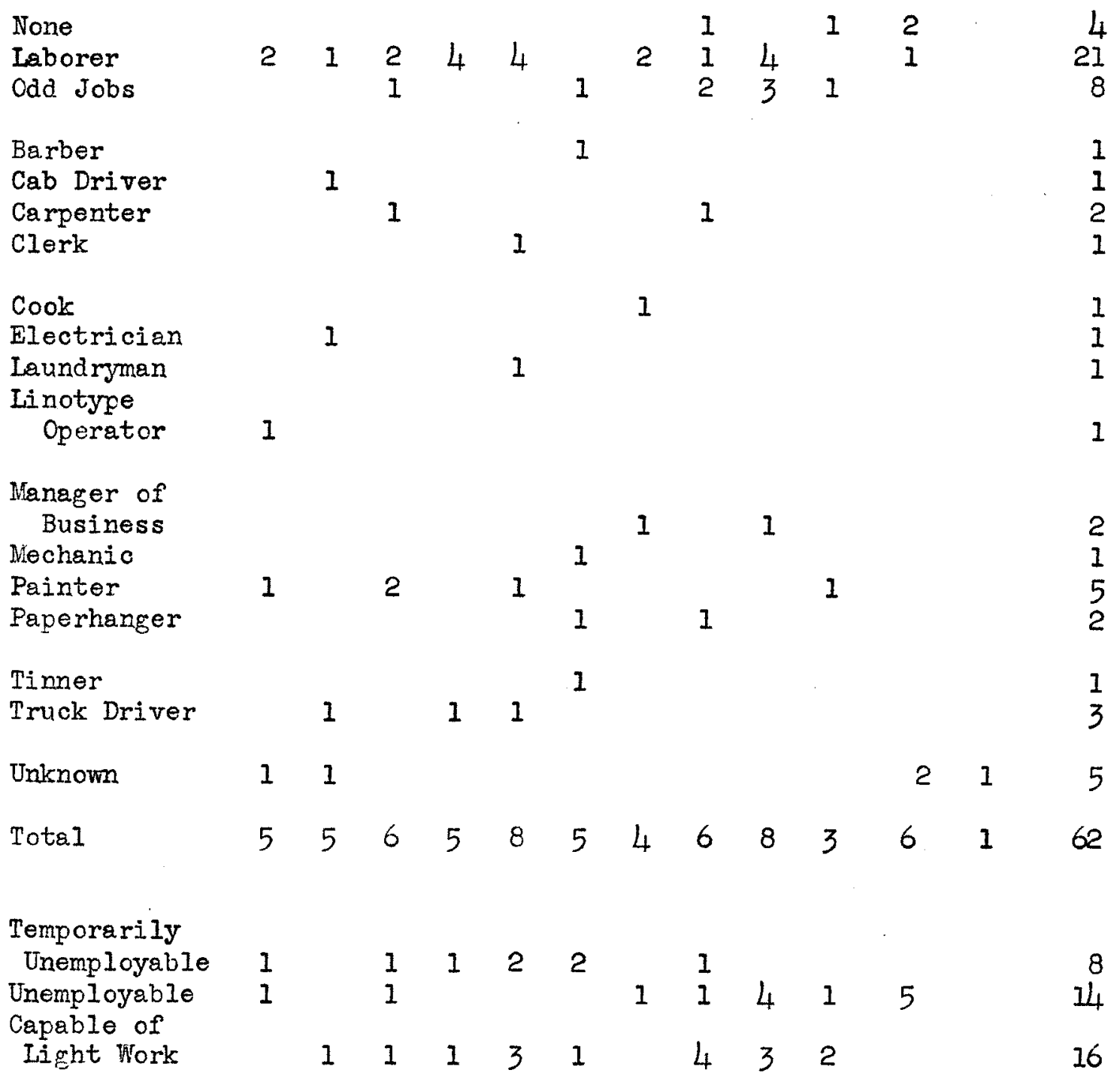


work, one of the latter was chosen. In only 62 of the 113 white families the wage earner proved to be the male who was the head of the family. Classifying this group in the same manner as all the adult males, we find that thirty-eight were unemployable or able to do light work only. There seems to be a lar ge number of old er persons. There were twelve who had either no occupation ar, its equivalent, were equipped for odd jobs only. Another twenty-one were unskilled laborers. In education, again, the group had very limited advantages. There were thirty-six white families in which the only possible wage earner was a woman. Eighteen, or half, of these women had ohildren at home under sixteen. Nine were widows, while two had never married. Eighteen were classified as separated, divorced or deserted. Seven had husbands who were incapacitated or in jai1. Twenty of the women had diagnosed physical handicaps or disabilities. Seventeon had no occupation whatever; the rest had practically no skills to offer a prospective enployer.

In fifteen of the homes, the children were expected to support the family. In only three of these homes were there as few as two persons. Only two of the children had any definite occupation.

Including the nine male children wage earners, we find that of the seventy-one white male wage earners, twenty-two had never had a steady job. Inf ormation as to length of unemployment was given for thirty-five of the fifty-one totally unemployed. Although over one-half had been unemployed less than one month, thirteen had been unemployed one year or more. For the purposes of 
Table XXXVII

White Male Wage Earners; by Age and Length of Unemployment.

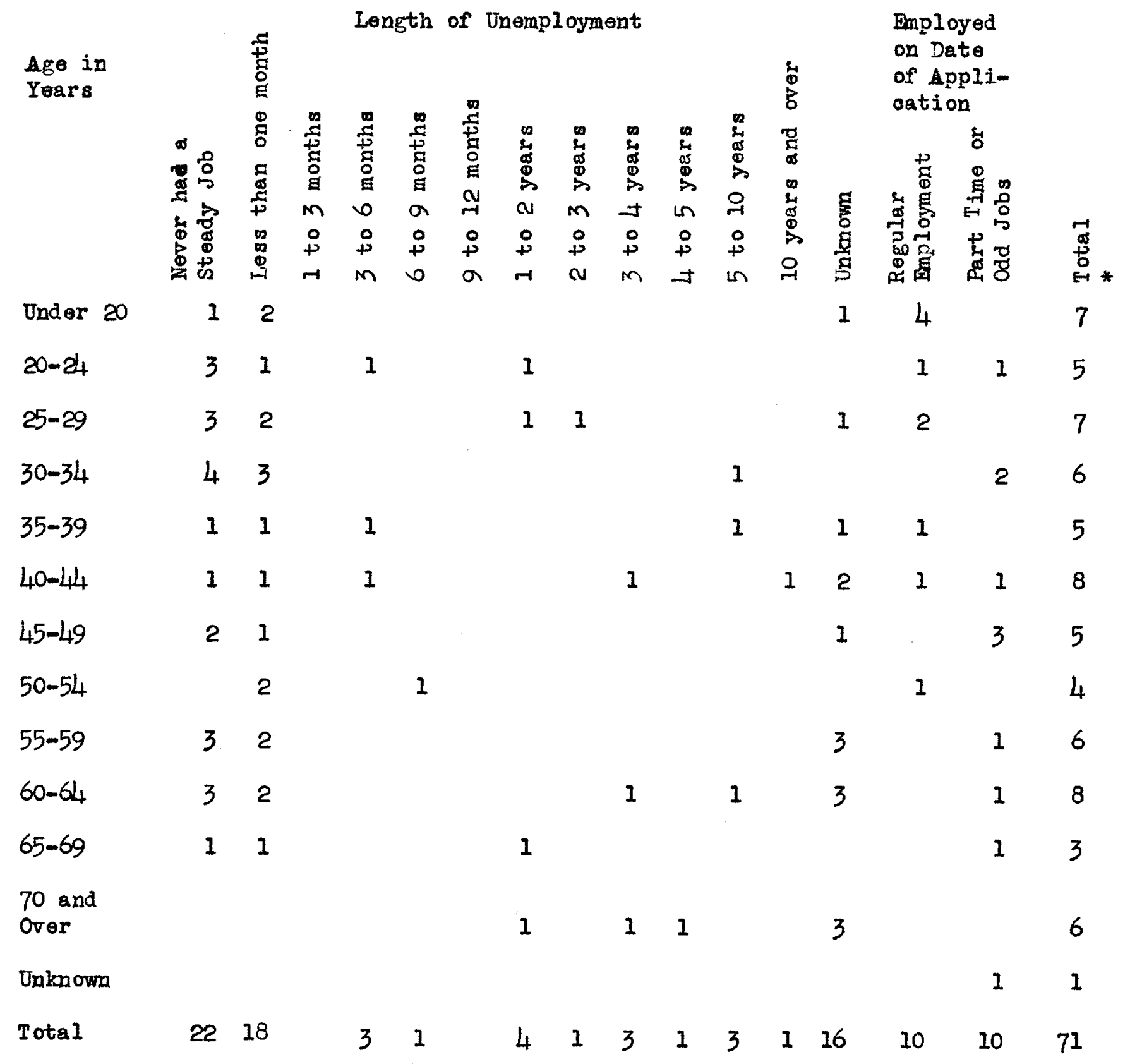

* Total includes all oolumas except "never had a steady job." 
Female White Wage Earners; by Age, Occupation and Health. (includes heads of families only.)

Occupation

\section{Age in Years}

20- 25-30-35- 40-45-50-55-60-65-70 Un- Total

$\begin{array}{llllllllll}24 & 29 & 34 & 39 & 44 & 49 & 54 & 59 & 64 & 69\end{array}$ and known

over

None

5

2

312

12

1

Clerk

Charwoman

Domestio

1

1

1

2

1

1

4

Leundress

Seamstress

Telephone

Operator

Prostitute

1

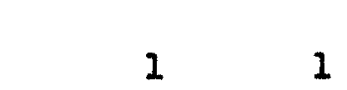

1

$\frac{1}{2}$

Unknown

111

111

1

8

Total

5133

43

6233

$3 \quad 36$

Temporarily

Unemployable Onemployable Capable of

21

2

3

22

1

13

Iight Work

1

13

11 
this table, employment on the W.P.A. Was not counted as "employment." Ten of the seventy-one wage earners had regular employment at the time of application; an additional ten had part time employment or odd jobs.

In all of the sixty-four negro families, there were only twenty-one mele heads of families who could qualify as wage earners. Of these, only five were physically able to work. They represented a very limited range of occupational skills. Nine were accustomed only to odd jobs. Five were unskilled laborers. Ten of the twonty-one had never had steady jobs. As a group, they showed much greater duration of unemployment than did the similar class among the white families. Four had part time employment or odd jobs at the time of application. None were working full time. Of the fifteen unemployed men for whom length of unemployment s known, eleven had been unemployed for two or more years.

A woman was the only possible wage earner in thirtyoight of the sixty-four pogro families. Seventeen of these were widows; thirteen were separated or had been deserted. Two had never married. Six were living with their husbands but the latter was incepaoitated.

The social desirability of foroing the se wamen to work is placed in considerable doubt by the fact that fourteen had children under sixteen years of age in the home. Twenty-four of the women were not physically capable of holding regular jobs, although nine of this number could work on a limited basis. The majority of them were danestios, or had eked out a precarious living 
Table XXXIX

Na le Negro Wage Earners; by Age, Occupation and Health. (includes heads of families only.)

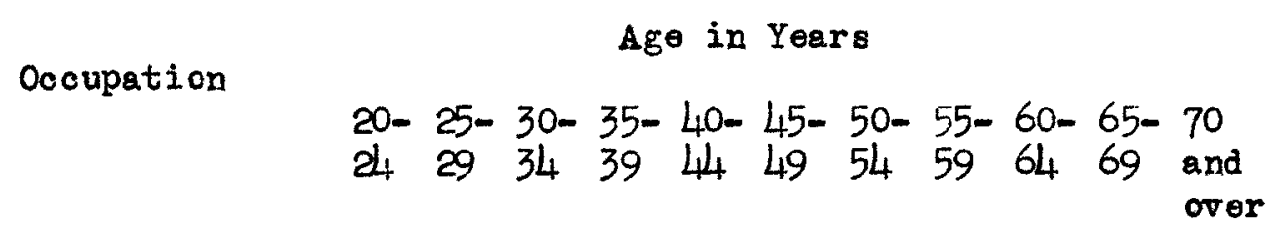

Total

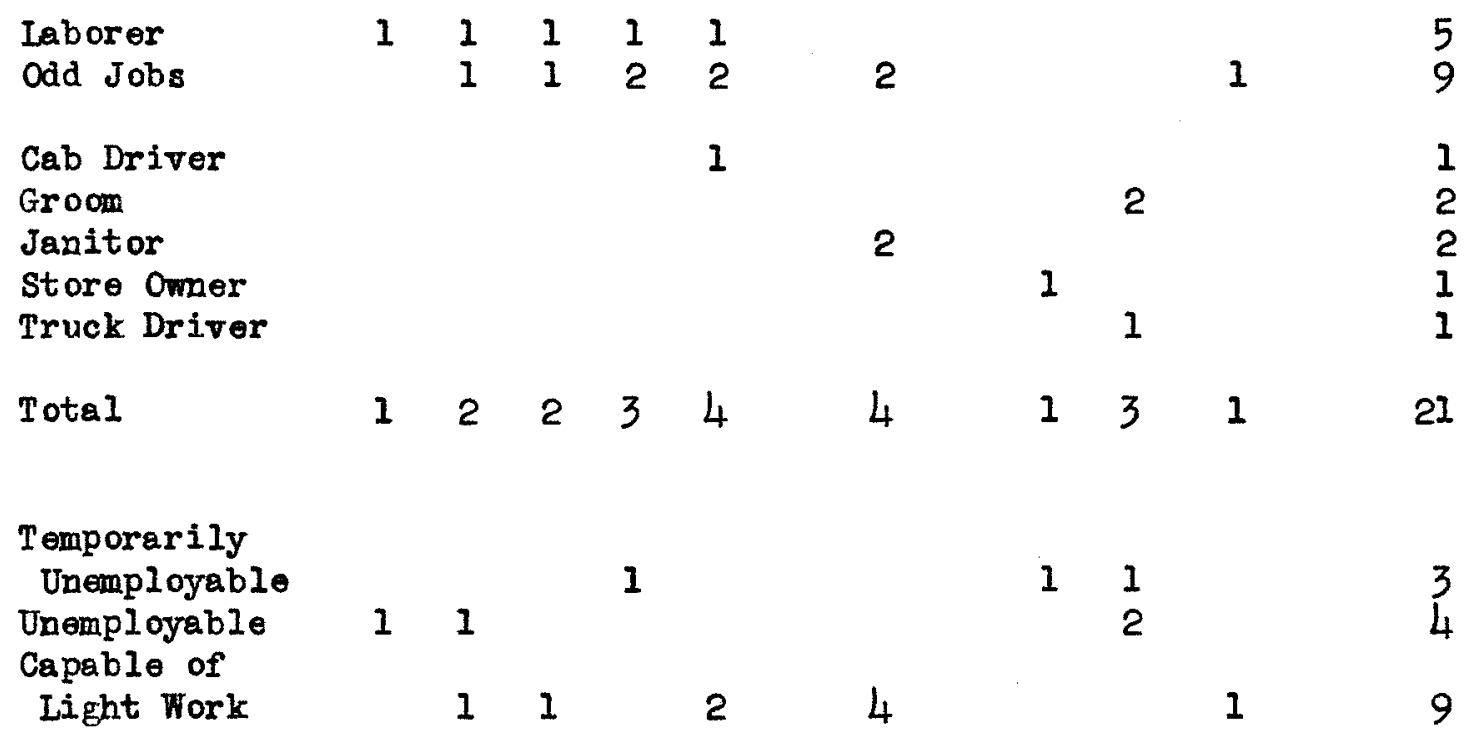


from "day work." This latter classification is equivalent to "odd jobs" in the tables for men.

Five negro femilies were dependent on children for support. One son, thirty-two, was an unskilled laborer. Another son, twenty-three, with an eighth grade education, was a machine operator on a W.P.A. project. There were two daughters, both twenty-three, with one year of college. One was ill but still working for the N.Y.A. The other had a regular job as a donestic. In the fifth family, the twenty-nine year old daughter had only odd jobs as a domestio.

Inoluding these three daughters, we find that, of the forty-one female negro wage earners, seven had either never worked or never had a steady job. Of the fourteen who were unemployed and for whom data were available, twelve had been out of work for less than nine months. This is in striking contrast to the male group, who showed much greater duration of unemployment. Four of the women had regular jobs and nine were partially employed at the time of application.

The survey conducted in 1940 commented on the vocational possibilities of the families studied at that time. ".... this group has little to offer the labor market in the way of skills and brawn. There is plenty of evidence of desire to work but ignorance of how to work." "One of the nost striking problems ... was the large number of families whose wage earners for years had been depending wholly on odd jobs." The families gave "an expression of hopelessness about their future which seomed disastrous to 
Table XL

Negro Wa le Wage Earners; by Age and Length of Unemploymant.
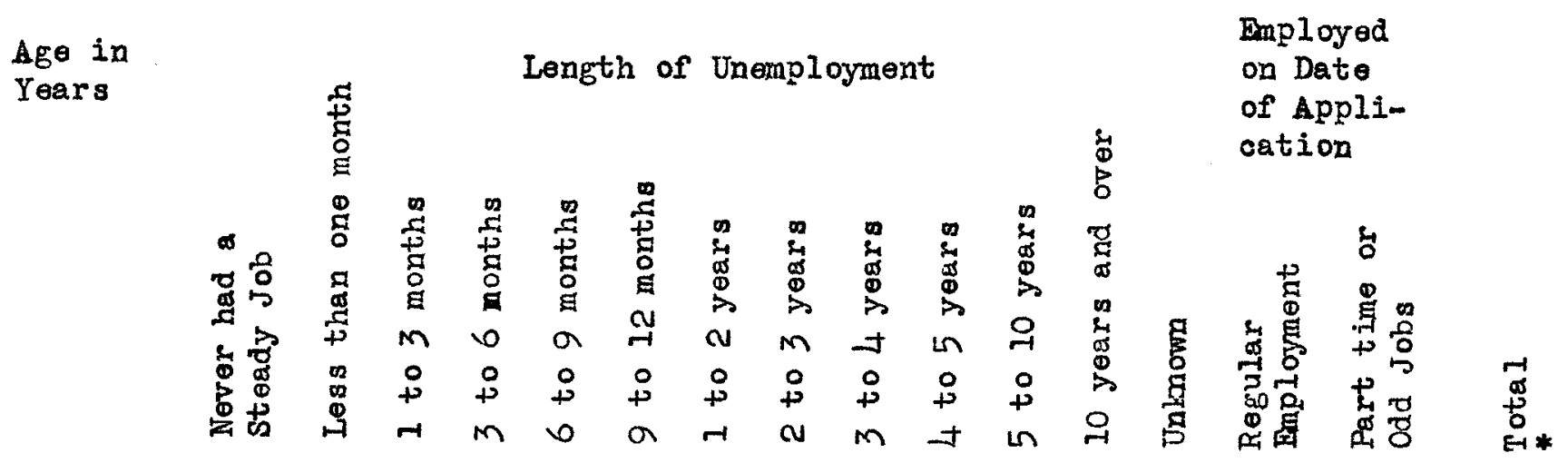

Und or 20

$20-24$

11

$25-29 \quad 2$

1

1

2

$30-34 \quad 1$

11

1

35-39 2

2 3

40-44 21

1

24

45-49

$50-54$

1

1

4

$55-59$

$60-64$

11

1

1

$65-69$

1

1

3

70 and

Over

1

1

1

Unknown

Tote 1

$\begin{array}{llll}10 & 1 & 1 & 1\end{array}$

144

34

4

23

* Total includes all columns except "never had a steady job." 


\section{Table XLI} $\frac{\text { Female Negeo Wage Earners; by Age, Occupation and Health. }}{\text { (includes heads of families only•) }}$

Ocoupation

$$
\text { Age in Years }
$$

Under 20- 3-30-35- 40- 45-50-55-60-65-70 Un- Total $\begin{array}{lllllllllllll}20 & 24 & 29 & 34 & 39 & 44 & 49 & 54 & 59 & 64 & 69 & \text { and } & \end{array}$ over

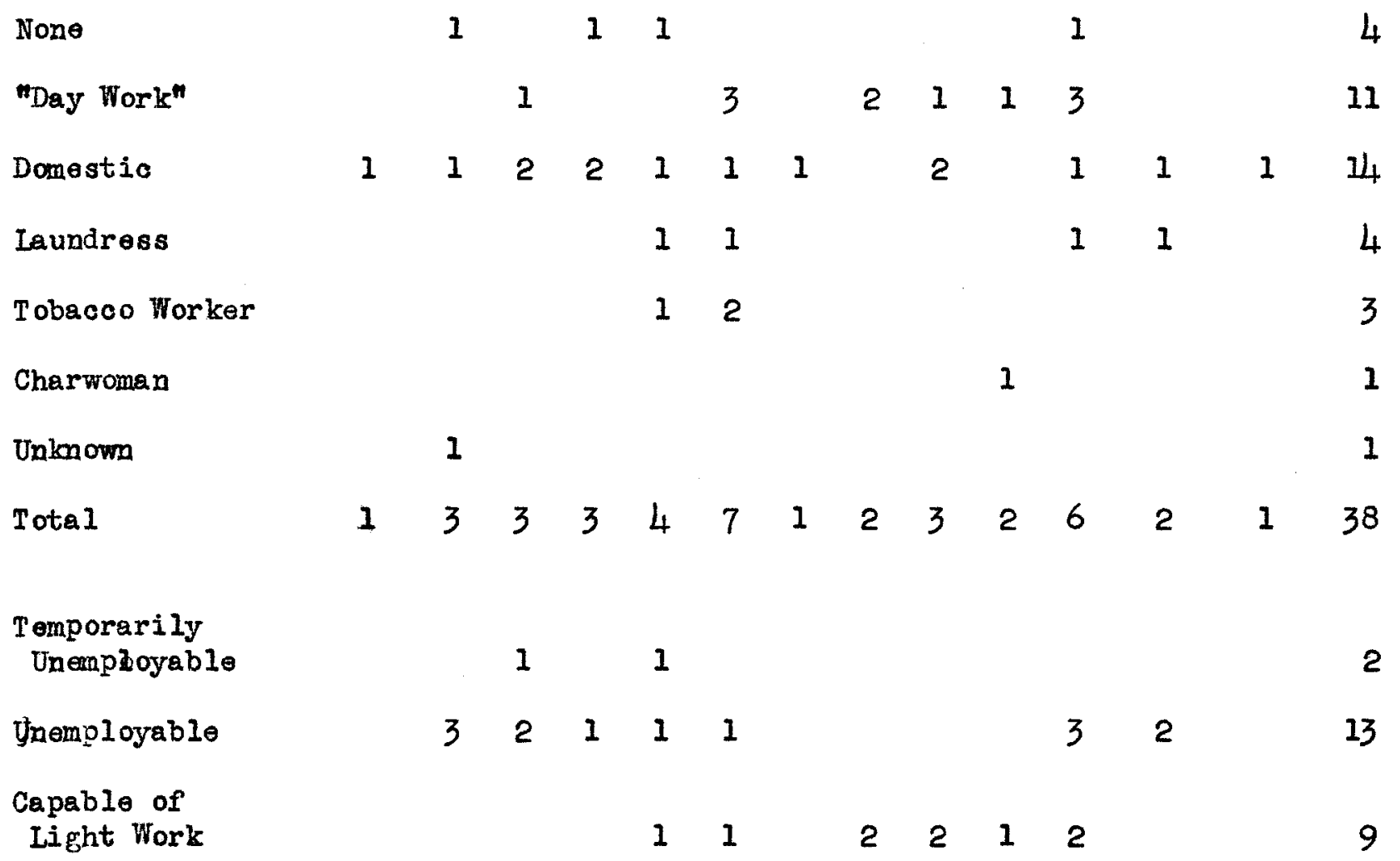


to future adjustment." 56

From this evidence it is apparent that these families had little capacity to find gainful employment. Almost half were dependent on women wage earners. These women were untrained. The white women had few occupational skills. The colored women viere chiefly donestics, not capable of earning a living wage. Nany had children who needed care and supervision. The wage earners as a whole were in ill health. They tended to be older. With little education and less vocational training, most could not hope for any work at all. Those who were physically able to work were the marginal workers, not able to compete successfully with others possessing more ability. During Norember and December, Iouisville was beginning to feel the effects of the program of national defense. Business conditions had improved. There are no dependable statistios which would give an indication of employment conditions, but it was common knowledge that there were meny more jobs available than there had been in years. The limitations of the wage earners in the group under consideration lead us to wonder how much they could hope to gain from increased industrial activity.

These families were rejected by the agency. They were asked to depend on their ow rescurces. It is not difficult to see why they found this impossible, or at best, hard to do.

This analysis shows the situation of the families at the time of rejection in November and December, 1940; following is an analysis of their situation in larch, 1941.

56. Tbid., pp. 31, 23-24. 


\section{E. Family Adjustment.}

Home visits were made to eighteen, or approximately ten per cent, of the families refused help in order to learn what adjustment they had made to their rejection and in order to gain insight into their current situation. Application of the findings of the home visits to the entire group would not be statistically valid. However, presentation of case summaries will give some insight into a few of the types of adjustinents made by families who find themselves refused assistance.

The cases for home visiting were chosen at random from the entire group, after the elimination of non-residents and those active at the time with M.B.S.S. and other social agencies. AlI of the visits were made during the period from March 19 through March 26, 1914. It was not always possible to obtain all of the information desired. Some persons could not remember. Others saw no need for discussing certain points, while one family was suspicious and evasive.

Seven of the eighteen families had been refused because of the income in the home at the time they made application. These seem to fall into two groups. Three families applied because a crisis disrupted their mode of life. Four families felt unable to endure longer the pressure of living on an inadequate scale.

The A. family was refused relief on November 25, because of an income of $\$ 18.00$ a week, which was well over the relief 
grant for a family of four. A fire had destroyed the home, groceries, and most of the family's clothing. They had no savings to tide them over the crisis. Mr. A. had a weak heart. He had difficulty finding work. Although he was then earning $\$ 18.00$ a week, he still had many debts left from a previous period of irregular employment. The priest had given the family $\$ 5.00$ which they had used to buy coal. Because they still had credit at the grocery and an $\$ 18.00$ wage which would cover food and the current expenses, the agency thought they could manage. On December 31, Mrs. A. re-applied. Mr. A. was earning only $\$ 9.00$ a week because of the severe weather. The American Red Cross had helped some with furniture and clothing, but Mr. A. had other debts. The A.R.C. felt the family was in need of food and coal, but the family income was too high to permit supplementation by the Bureau. At the time of our visit, the family was again living in the home, which had been repaired. It was a very attractive frame bungalow. Mr. A. had obtained work as a laborer, earning 24.00 a week. Mrs. A. felt they had been in real need and could not understand the rejection. There had been no relatives able to help them. The neighbors had given them a place to sleep while their house was being repaired. They had had to buy new clothing and furniture, although the Red Cross had been of some assistance. Rent had gone unpaid for four months. Bills had accumulated at two groceries, one in $\mathrm{Mr}$. A.'s mother's name since Mr. A.'s credit was no longer good. Four life insurance policies, costing a total of $\$ .60$ a week, were almost lost because they could not keep up payments. The family had reduced all expenditures to 
an absolute minimum, spending only 4.00 weekly for food. At the time of the visit, they were just beginning to get on their feet again. All the back rent was paid, insurance payments were up to date, and the bills at the grocery and for the furniture were gradually being diminished. They had not yet paid the neighbors for keeping them, but planned to as soon as possible. Mrs. A. expressed a great deal of discouragement. Because of his disability Mr. A. has difficulty finding steady work. When it was suggested that he investigate the possibility of obtaining training in less strenuous occupations, she expressed fear lest people learn of his weak heart and refuse to hire him.

Mr. and Mrs. N. have five children, ranging in age from four to thirteen. When Mrs. N. made her application on November 19, Mr. N. had been ill for two months. He had been able to work only a few days each week and had been away from work entirely for the past week. Since he earned 17.00 a week when regularly employed and since Mrs. N. was earning a few dollars a week as a maid, the family was told to reapply if he was not able to return to work in a "reasonable" time. The family had no relatives who could help during Mr. N.'s illness. Mrs. N. had obtained her work from a nearby hospital, because of its concern about the family. The family of seven was completely dependent on her wages of three or four dollars a week for food. Rent was kept up to date by means of a 30.00 loan from a personal loan company. Friends lent undetermined amounts, most of which went for coal. The American Legion and the Cabbage Patch Settlement donated groceries at 
Thanksgiving and Christmas. The latter also gave $\$ 5.00$ for food. The children were able to continue in school by means of clothing given by the visiting teacher. The man had returned to work just before Christmas, but was still not feeling well in March. Mrs. N. continued to work. In March their combined income was $\$ 21.00$ a week. With five children it was not easy to pay their debts but they were gradually doing it. The last of the $\$ 30.00$ loan had been repaid two days before the visit. Insurance payments were again on a current basis. Mrs. N. found it very taxing on her strength to work all morning and keep house as well. All the children were in school, the youngest in nursery school, so their supervision was no problem during the winter. However, she apologized for the appearance of the house, saying she simply did not have time or energy to do all she would like. Mr. N. apparently is a good worker, although unskilled. He has never had any trouble finding work but none of his jobs had lasted longer than a year. Mr. G. had completed two years of high school. He had been a sheet metal worker and carpenter in the past. He had worked for himself and managed fairly well. Because of an injured knee he could no longer do any work requiring much activity. At the time of application, he was awaiting reassigment to a W.P.A. project as a clerk. Mis. G. is epileptic and has never been able to work. There were four children in the home, a boy of twenty made a small amount from odd jobs. In addition to $\$ 12.00$ a month in food stanps, there was an income of $\$ 22.00$ from another son's C.C.C. employment. The Bureau thought the family could manage until Mr. G. 
obtained work: The income was in excess of the M.B.S.S. relief budget. They were living in a condemned house so paid no rent. The house had been condemned for three years, ever since the flood. Needless to say, it was in very bad repair. The family had neither gas, lights, nor water. The outside toilet had washed away in the flood and had never been rebuilt. The family used a comode and emptied it "where the toilet used to be." Mr. G. applied for help on November 13. He was not reassigned to W.F.A. until the following February. During that time the family "just scratched for it." The family of six lived on five or six dollars a week for food. Insurance lapsed. The children managed to stay in school, but their clothes became ragged. Having a great fear of debt, the family preferred to do without rather than borrow or buy on credit. There were no relatives who could help. At the time of the visit, Mr. G. was earning $\$ 60.00$ a month on the W.F.A. The son who had been in the C.C.C. was back in town. He spent most of his time with a friend with whom he peddled. From his meager earnings he gave his mother about $\$ 1.00$ a week. The sixteen-year-old son had just quit school, hoping to find work. Being very small for his age and having only an eighth grade education, he finds it impossible to obtain a regular job. So long as the family pays no rent, they can manage on their income. But the home is very undesirable. They would like to move, but can find nothine they can afford. From these three cases it is apparent that great deprivation and suffering was caused by the discontinuance of the family income even though the income was regained within three 
months. Just barely managing when all goes well, the least disturbance leaves the families defenseless. Then children go hungry, standards are lowered, debts pile up, and the family is left less able to meet the next emergency.

The next four families, also refused because of regular income, illustrated the meaning of long time dependence on inadequate earnings.

\section{Mr. C. has worked irregularly for the same wrecking} company for the past ten years. He lost a week's work because of illness in the family. Regularly earning \$20.00 a week, he was refused public assistance since he had already returned to work. His income more than covered the relief budget for a family of seven. Mr. C.'s oldest child, a boy of thirteen, has some sort of brain injury, is partially paralyzed, and "has fits." In November, he underwent a brain operation at the City Hospital. Another child was at home with mumps. The family was extremely worried. Mr. C. spent his time going to the hospital to see if James were worse and coming home to nurse Bill. There were three other children in the home. One was left a heart cripple by rheumatic fever and another has tuberculosis. Mr. C.'s work has never been regular. His family has just barely been able to manage. At the time of rejection, rent was five months in arrears. The house was sold in November, 1940. The new landlord deducts the rent from Mr. C.'s wages before he gets them. Mr. C. went through several weeks' unemployment in January, 1941, because of influenza. Since then his wages have been cut to $\$ 18.00$ a week. The family 
adjusted to rejection by buying food and coal on credit. No relatives had resources. In Narch, the family did not feel able to manage on $\mathrm{Mr}$. C.'s earnings. They pay 3.00 a week rent for a frame cottage in poor repair. There is no gas or water in the home. Mrs. C. said they had only three or four dollars a week for food. The children get no milk or fruit, and green vegetables only occasionally. The family has no extra money for clothes. They go as long as they possibly can and then buy a few "on time." Mrs. C. knew this meant paying "double prices" but she never had enough cash. She had thought of returning to the M.B.S.S., especially for shoes for the children, but "they were so cross" that she hated to. There were other needs in the home. There were not enough chairs or dishes to enable the family to sit around the table and eat together.

Mr. and Mrs. F. were refused assistance three times during the three month period. Because Mr. F. was able to do light work and the income of $\$ 57.00 \mathrm{a}$ month for five people was higher than the agency relief grant, the family was ineligible. There seemed to be no change in the situation when the visit was made. Mr. F. is a carpenter by trade. He suffers from pleurisy and chronic asthma. His asthmatic attacks are quite severe and he endures considerable pain. In addition he has dizzy spells. Mrs. F. has tuberculosis and arthritis. Although able to do her housework, she is not strong enough for regular work. However, she makes $\$ 50$ to $\$ 1.00$ a week by doing laundry. The oldest son joined the Army the day before he was to register under the 
Selective Service law. The nineteen-year-old son is the wage earner in the family. He makes \$12.00 a week as a laborer. The other child, a girl sixteen, is still in high school. Also in the home is Mrs. F.'s feeble-minded sister, who gets $\$ 75.00$ a year as a pauper idiot. The family lives in a four room cottage in excellent repair. They spent many hours painting and papering. Mr. F. was dressed immaculately. This was quite remarkable, since he had no clothes except those he had on. The family has not been able to buy any clothes for several years. All they have they got through the Municipal Bureau from the W.P.A. Clothing Center. At the time of the visit all were in rags except the daughter, who managed somehow to find adequate clothes. The son had a few clothes, which his older brother had given him when he joined the Army. This son had promised to send money home, but had never done so. Each letter told how his last pay had been stolen, or had been less than usual because of some mix-up. The family still believed he intended to send money, but it seemed doubtful to the interviewer. The family manages to live very decently and with pride on their low income. They are able to buy three or four quarts of milk a week and some fruit, although they have green vegetables only occasionally. Mr. F. cannot eat all foods because many bring on his asthratic attaciss. He felt that he needed a special diet and, therefore, the M.B.S.S. could supplement, but the City Hospital reported that he did not.

Miss $L$. is sixty-eight. She lives with her two older sisters on an income of $\$ 30.00$ a month. One sister was described 
as senile, the other as "nervous." For fifteen years, to 1933, Miss L. had earned $\$ 25.00$ a week as a seamstress at a large department store. She had worked in the same capacity for private families until 1936. Since then she had obtained sewing to do at home, but earned only a few dollars a month. It was apparent from talking with her that she was extremely nervous. She felt that sewing made her more nervous. She complained of failing eyesight. The family had had much higher standards in the past. The furniture was very substantial and included a grand piano. They had owned considerable property. All that was left was a building renting for $\$ 50.00$ a month. Payments on the mortgage took $\$ 20.00$ of this. Their own rent is $\$ 20.00$ a month. The interviewer at the Bureau had suggested that they move to cheaper quarters, thus they would be able to live on their income. The family was resistent to this suggestion. They lived in a very nice five-room cottage in a pleasant residential district. This meant a great deal. Very proud, they had never asked relatives for help. Relatives did not know of their need. To move would be to publish the fact. After the rent, water, gas and electricity bills are paid, the three sisters have only four or five dollars a month for food and clothing. Miss L. estimated they spent about one dollar a week for food. All three were thin and seemed definitely malnourished. They were two months in arrears with their rent. None had enough clothing to enable her to venture far from home.

Mr. H. had also been accustomed to a higher standard of living than the $\$ 69.00$ a month income afforded his family of five 
at the time of rejection. Mr. E. had had excellent jobs as chauffeur for prominent families. He had moved to Florida where he lost all his money, his home and his furniture in a hurricane. His oldest son died soon after in a hunting accident. Mr. H. "hasn't been the same since. He has "spells" similar to epilepsy. Mrs. H. has noticed that his spells occur only "when he is crossed," that is, when things go vrong. From her description he seemed very nervous and bordering on paranoia. She was short and abrupt with her daughter. Her hands swell, the skin cracks and reddens. The doctors at the Portiand Health Center tell her to keep her hands out of water, but add that the trouble is due to nervousness. Because of this "spells" Mr. H. has not been able to work for many years. Mrs. H. earns fifty cents a week by doing laundry work. The oldest boy, an honor graduate of high school, earns 16.00 a week as a comnercial artist. The other son, also an honor student but still in high school, manages to buy his own clothes and school supplies from his paper route. The family has managed to maintain a high standard of living. The rooms were clean and attractively furnished. Mrs. H. knows how to care for her possessions. She showed us a carpet brush in excellent repair which she had used for ten years. The family was careful not to go into debt. The only debt was $\$ 400.00$ owed Nrs. H.'s brother. He does not expect this to be repaid. Although they are able to allow only 6.00 a week for food, Mrs. H. said they had eggs, milk, fruit and green vegetables. She felt these essential since the two boys are both attending the tuberculosis clinic as a 
preventative measure. They are not able to buy any clothing. Relatives give "hand-me-downs" which Mrs. H. carefully remodels. For Christmas and birthdays, the relatives always give shoes.

All of these four families had incomes which covered more than half of the minimum budget, if the budget for the L. sisters is computed with a more proportionate amount for rent. Even so, it is apparent that they are just barely managing to sustain life. Any slight blow can be catastropic. It will take very little to upset the delicate equilibrium and bring chaos into the family. We see sickness, nervous tension, unhappiness, children leaving school at an earlier age than did their parents.

One of the families visited was refused public assistance because of credit resources. Mrs. F. said she was awaiting W.P.A. reassignment after a lay-off because of a disagreement with her supervisor. Mr. P. completely incepacitated by high blood pressure, had not worked in three years. Iiving with the couple was their seventeen-year-old daughter and her infant son. There were no relatives able to help. The woman, anticipating her layoff, had saved groceries ahead. However, she had not been able to save enough to carry the family through the anticipated month of uneraployment, much less the actual two months. During that time the family of four persons lived on $\$ 8.00$ a month in food stamps. The milkman let them have milk on credit. Rent was unpaid. A friend lent 4.00 for coal. Life insurance payments could not be kept up to date. They managed to average about $\$ 4.00$ a week for food but let other needs go unmet. Mirs. P. was again 
working on the W.P.A. in March. The twenty-one-year-old son had returned home, and earned $\$ 16.00$ a month from his N.Y.A. emplojment. The family was beginning to get its debts paid. Rent was only a little more than a month in arrears. The electricity had been cut off in February, but the family hoped scon to be able to have it turned on again. They were able to manage fairly well on their income principally because rent for the three-room frame cottage was only $\$ 7.50$.

The two families classified as having been referred to the H.F.A. might as easily have been included in the group of those asked to live on credit. Mr. B., fifty-eight years old, is a carpenter by trade. Partially incapacitated by rheumatism, he has been working for the W.P.A. since 1936, classified as a carpenter. He found that this work was so irregular that he did not average more than $\$ 7.00$ or $\$ 8.00$ a week. In October, 1940 , he requested reclassification as a laborer. He was assigned, but found the work too difficult. When he applied at Ir.B.S.S., he was advised to get a statement from his last employer (which the W.P.A. Office had requested because he had had private employment) and return with it to the W.F.A. office. He was eligible for immediate re-employment. During the period of his lay-off, Mr. B. did not receive food stamps because of some clerical mistake in the office. He, his wife and their eleven-year-old grandson averaged $\$ 5.00$ a week for food, because of the kindness of their grocer. There were no relatives able to help. The family got two months behind with their rent of $\$ 10.00$ a month. At the time 
of the visit, Mr. B. was working as a night watchman. The family had almost caught up with their rent but still owed the grocer $\$ 55.00$. Now that $\mathrm{Mr}$. B. is working, the femily spends about $\$ 7.00$ a week for food. On this they can get meat, milk, fruit and some green vegetables. The grandson has had enough clothing to enable him to stay in school. Mrs. B. is not well, she is almost completely deaf and scarcely able to do her housework.

Mrs. E. Was laid off the W.P.A. on October 25 because of illness. She received her last pay, of 23.40 , on November 2. When she applied for help on November 5, she was awajting reassignment and was therefore referred to the W.P.A. Mr. E. Was completely incapacitated several years ago by an accident which crushed his skull and injured his leg. He was partially crippled and suffered from frequent sizzy spells. Mrs. E. has had to support the family, including two smell children, since then. During the period of Mrs. E.'s unemployment the family followed the usual pattern. They pared expenses to a minimum, spending only $\$ 3.00$ a week for food. Rent got two months in arrears. Insurance lapsed. The only source of income was $\$ 8.00$ a month in food stamps. The American Legion and the St. Vincent de Faul Society both helped with groceries. The family had relatively high standards of living. They lived in a nice residential section of town. The home was noat and well furnished. Mrs. E. was again employed in March. Mr. E. had just begun to receive $\$ 30.00$ a month as a pension because of his disability. The combined income well covered the minimum standard budget. However, the effects of 
their period of deprivation were still in evidence. Rent was not quite up to date. The children were small and thin. Mr. E. felt they had not received sufficient food.

We see from these three cases families thrown upon the mercies of landiords and grocers, forced to beg from friends, or accept help from relatives only slightly better off. These periods of deprivation leave permanent marks on the children. The wageearners return to their jobs discouraged and disheartened by a load of debts. The wages are spent for repayment so that even while employed the families must suffer.

Six of the families visited were rejected because they possessed untapped resources in relatives. Mr. M. had applied for Old Age Assistance but had been refused because it was felt his children could support him. He was rejected by Mr.B.S.S. on the same basis. One son, with two dependents, earns 44.00 a week. Another with a family of six is working but his income is unknown. One son-in-law earns 22.00 a week, while another earns Both have two dependents. Mr. M. is seventy-six. His wife is sixty-nine. He worked as a janitor in a bank for seventeen years, up to August, 1939. At that time he was so feeble that he could work no longer. At the time of the visit he insisted that he was not sick, he just had "the shakes." However, he had not gone out of his home for several months because he did not want "to die on the streets." Mrs. M. is approaching senilty. She has some sort of "growth" and is not able to work. Since Mr. M. Iost his job, the couple has managed by cashing insurance policies. 
The married children have helped. The family was not able to give exact information as to the amount or source of their incone. Mr. M. earned, both at the time of the rejection and of the visit, $\$ 6.00$ a month popping the corn his son sold. Mrs. M. earned possibly a little more by selling crocheting. The children assisted with food. The rent for the four rooms was 12.50 a month. The home, in which the family had lived twenty-one years, was very comfortable and included a private bath. Mr. and Mrs. M. showed considerable antagonism toward both the Old Age Assistance Department and the Municipal Bureau. They did not feel their children were able to help them. The son, earning 44.00 a week, has had many doctors' bills because of cataracts on his eyes. They felt that he should not be asked to lower his own standard of living. Just because a person lives in a brick house, they said, is no sign he can support his parents.

Mr. D. had completed three years of high school. He was a skilled auto mechanic, but not well adjusted emotionally. He had excellent jobs up to June, 1940, and also maintained a small repair shop at home. When working, his earnings averaged $\$ 35.00$ a week. However, he became ill with some sort of undiagnosed stomach disorder, suspected of having a neurotic origin. When Mrs. D. applied for help on November 6, he was working on a commission basis. Because of his ill health he was not able to work steadily. The past week he had eamed only 33.50 . There were three children in the home, the oldest a son of fifteen. Another son, aged twenty, was not living in the home. 
Earning 23.00 a week as an auto mechanic, he preferred the independence of living apart. The Intake interviewer sugrested that if this son were to move back into the home, the family could manage on his earnings. However, this son was not willing to return home. His mother agreed that he could not help the family, having many debts of his own. She was evidently very proud of him and showed the interviewer his picture, asking if he weren't handsome. There were no other relatives able to help. Several years ago, one of the children had been run over by a prominent citizen's automobile. Since then, this man had taken a keen interest in the family and had helped in times of need. When the family was rejected by the Bureau, rent was two months in arrears and the landlord, although friendly (he had helped with groceries) was forced to ask them to leave. The friend paid their rent at a new address and gave $\$ 5.00$ a week for food. Soon, however, he died, leaving them without resources. The man managed to get a few odd repair jobs. The church gave baskets at Thanksgiving and Christmas. At the time of the visit, Mr. D. was again ill. In addition to his stomach disorder, he complained of a sore throat and excessive coughing. He had attended the tuberculosis clinic the day before where he had received medicine but no diagnosis. Mrs. D. had obtained work at a nearby hospital. She earned 9.35 a week in addition to two meals a day. The family was completely dependent on her earnings. After paying 5.00 a week for rent, the remainder was used for food and insurance. The latter amounted to $\$ 1.00$ a week. These were new 
policies since the old had lapsed after rejection. Mrs. D. seemed very tired and discouraged. She worked hard and felt underpaid. The children were not getting adequate food. The youngest boy, weakened by rheumatic fever, was malnourished. Although the family still had sufficient clothing, there was no room in their budget for replacements.

Mrs. K. was referred to the M.B.S.S. by the Family Service Organization. A widow, sixty years old, she was nat able to work because of high blood pressure. She owned a five room house, in which she had lived twenty-eight years, with a $\$ 600.00$ mortgage on it and a lien of $\$ 1,000.00$ for repairs. She was living in her sister's home, which included her brother, brother-in-law and another sister, where there was an income of over 80.00 a month. It was suggested that she could continue to live with this sister. If she rented her house, she could be self-supporting. After rejection she moved back into her ow home. The trip to the Bureau had been made in the cold and damp. Exposure to the weather precepitated pneumonia. For many days she lay alone. The gas and electricity had been turned off and she had only candle-light. Fer brother, who was working irregularly, gave groceries as did her sister. Neighbors would bring in food. After her recovery, she rented three rooms to a family for 18.00 a month. Her brother began working more regularly and sent up to $\$ 5.00$ a week. She explained that, since he drank and gambled, he could not be depended upon. She has a friend who recently started spending each weekend with her. This friend pays from 1.00 to 1.50 each time and 
usually brings groceries as well. Mrs. K. used to be a nurse and occasionally gets .25 or .50 from neighbors for her services. She has made 12.00 from selling chances on a quilt given by her sister. On the day before the visit, Mrs. I.'s sister came to live with her. This sister is quite feeble, and recently injured her knee. She prefers staying with Mrs. K. rather than the sister better able to care for her, because Mrs. K. "understands" her better. By the various devices mentioned, Mrs. K. is able to manage fairly well. By March she was up to date in her $\$ 3.30$ week:ly pajments on her house. She had been unable to pay for three months during the autumn. She has never made any payment on the $\$ 1,000.00$ for repairs. These were made without her consent and against her will. Lawyers assure her that she is not liable. The tenants pay for the gas and lights. She can spend about $\$ 2.00$ a week for food. She estimates that she has enough clothing to last several years if not the rest of her life. Additional income may be forthcoming from renting another room. She can do this if she can get her furniture away from the present tenants. They are very dirty and careless of her property. She would like to ask them to move, but is afraid to do so since she is so dependent on their rent.

Mrs. O. has never had a steady job, only day work, odd laundry jobs, and work for room and board. She is not well and cannot do heavy work. Her eyes are quite weak. Mrs. O. had been living in a rooming house. When no longer able to pay rent, she was allowed to stay while friends brcught her food, but after 
several months, she was forced to leave. There was no one able to help her except a cousin. Since there was nothing else to be done, the cousin shared her home. The cousin pays 89.00 a month for a four-room cottage, so has plenty of room for Mrs. O. However, the additional food and coal are a hardship. The cousin earns 12.00 a week as a domestic, and sends $\$ 4.00$ or $\$ 5.00$ a month to her daughter. Insurance on herself, her daughter and grand-daughter amounts to 2.90 a week. The cousin is given two meals a day by her employer, nevertheless, she was willing to give Mrs. O. room and boord. When applying at the Bureau, Mrs. O. requested only coal. The Intake interviewer suggested that she could find laundry work to pay for this. There seemed to be a friendly, harmonious relationship between Mrs. 0 , and her cousin. However, Mrs. 0 . did not like being a burden on some one not really responsible for her.

Because of her age, sixty-two, a large goiter, extreme nervcusness and high blood pressure, Hrs. I. may be considered unemployable. Before her husband's death in 1928, Mrs. I. had lived comfortably. His long illness depleted their savings. After his death she was forced to sell their home and use all his insurance to pay the debts. Since then she has lived with her nephew, his wife and two children. Mr. J., the nephew, managed fairly well until two years ago when an injury to his knee incapacitated him for several months. His knee is still stiff and limits the type of work he can do. He works as a credit investigator. At the time of Mrs. I.'s application in November and 
also in March, he averaged about $\$ 10.00$ a week. The house, a very attractive brick bungalcw, has a mortgage of $3,200.00$. The monthly payments are $\$ 32.30$. The furniture has a loan of $\$ 300.00$; monthly payments are $\$ 20.00$, but $\$ 7.50$ pays the interest. His parents live in the house but maintain a separate household, paying $\$ 5.00$ a month rent out of their $\$ 20.00$ monthly old Age Assistance grant. They owe 150.00 on their own furniture. The income in the nephew's home was above the M.B.S.S. relief grant. Mrs. I. was offered a place in the Home for The Aged and Infirm, but she was not interested. There was not much change in the family situation from November to March. Mr. J. had rented out a room for $\$ 8.00$ a month. In March he was still three months behind in his payments on his house and expected to be evicted at any moment. He had never been able to reduce the furniture debt. As soon as he gets the principal dow a little, he is forced to default on his payment so that penalties bring the total up again. The family of five never spends over week for food and averages less than that. When they were in such desperate circumstances last autumn, the parents gave their food stamps. At the time of the visit the family told how one \$.10 can of chili and two $\$ .05$ packages of spaghetti would feed all five for two days. Last summer they planted a garden in the vacant lot next door. From this they had vegetables all summer and canned enough beets and tomatoes to last throughout the winter. They said, "no one here eats much - we're all little eaters. Our friends will eat as much in one meal as we will in several days." 
Despite this striking inadequacy, the children seemed well-nourished. The family, however, seemed on the verge of disintegration. They showed a great deal of worry over their debts and expressed complete confusion and despair. Mrs. I. could not understand why she had not been eligible for public assistance. Her nephew is glad to keep her as long as he is able. Since his obligations on his debts exceed his income, it is probably only a question of time before he loses his home and furniture.

When Mrs. R. was rejected by the Bureau, she was counted as a case refused because of loss of contact. It seemed more logical to count her as being refused becaluse of resources in relatives. She was indefinite as to how she had managed in the past. Working as a domestic for colored people, she had lived with a cousin, paying her 2.50 a week. Her application for old Age Assistance was refused because of lack of proof of age. Mrs. R. was referred to the City Hospital for a nedical examination. A letter to the cousin asking her to come in brought no response, so it was assumed she would continue to help Mrs. R. Employed by the W.P.A. she also supported her daughter and infant grand-daughter. At the time of the home visit IIrs. R. claimed that the cousin was no kin, only a friend. She had been living with her for two years. Mrs. R. seemed quite senile and totally unable to work. She complained bitterly of the way she was treated. The interview tools place in the home of a neighbor, as ifrs. R. did not wish the friend to know who the interviewer was. She continued to live with her friend because there were no other arrangements she 
could make. She was wanted in the home in order to care for the infant grand-daughter. However, she did not receive proper food and was treated with disrespect and scorn. Often she received no food, so that the neighbors, being careful not to be observed, slipped her something to eat. Mrs. R. was not able to give any information about her friend's financial situation. It was apparent, however, that she was acutely unhappy. The friend had not been willing to discuss the matter with the Nunicipal Bureau and would never be willing to do so. Mrs. R. had planned to return to the agency, but did not feel equal to the long trip.

These six families, rejected because of rescurces in relatives, give examples of the hardship caused by the restrictive Intake policy. All of the families had made sone adjustment which enabled them to continue to live. However, there are undernourished children, tired and discouraged adults. Few can face the future with hope or the prospect of happiness. Debts have piled up. Families are tense and nervous from worry and anxiety. The principle of family responsibility have been stretched to include cousins, friends and others who cannot legally be considered responsible.

Two of the families visited were rejeoted because they had failed to complete their applications. Mr. and Mrs. J. have twelve living children, ten of whom were in the home at the time of the application. Since Mr.J. did not return with the requested medical report, there was no further contact and he was to receive unemployment compensation benefits in a week, his application was 
refused. He informed the visitor that this had not been done because he did not believe in doctors and would have nothing to do with them. Mr. J. had worked in the same laundry for eight years, ending October 15. 1940. He quit his job for another which did not materialize. After rejection, Mr. J. drew 12.50 a weel unemployment compensation benefits until he obtained a job paying $\$ 120.00$ a month. With a family of twelve it was necessary to spend almost all of this money for food. In March, the family allowed $\$ 10.00$ a week for food. They seemed to feel this was the least on which they could manage, and had spent the same amount during Mr. J.'s unemployment. Insurance had lapsed. Rent had been two months in arrears, but by March was paid up to date. The only debts were for furniture, glasses and clothing. They were able to manage fairly well by the device of paying very little rent. Their four roons on the third floor of a dilapidated, old building cost only $\$ 8.00$ a month. They were quite unattractive. The family was fighting a losing battle against rats, although they put metal sheeting over all the holes they found. The house was located in a disreputable business part of town. There were no play facilities for the children. The family showed many signs of strain. One daughter had been committed to Ormsby Village as a sex delinquent. A son could not be kept in school. His unhapoiness was manifested by running away. Mr. and Mrs. J. expressed their exasperation by having him committed to the institution. He was to go the day following the visit. The Juvenile Court worker thought that Mrs. J. shifted her 
responsibility as each child reached adolesence and did not properly supervise her children. Mr. J. seemed to be a very tense, emotional person and made the visitor wonder if psychiatric service was not indicated.

Nrs. Q., a widow of forty-two, used to be a tobacco stemmer. For the past two years she had had only occasional laundry work. When she made her application she was not able to give the names of her employers or the dates of her employment. Neither could she give the name of the place of employment of her married son. The application was refused for lack of information. Later a card was written to her son, nineteen, living in the home, asking him to come in to discuss the possibility of W.P.A. Since he did not come, it was assumed that the family had made their own arrangements. However, she was, at the time, earning only a few dollars a week. Living in one room with her two sons, nineteen and thirteen respectively, she was often actually hungry, although her church and friends helped with food. Rent was four months in arrears. The oldest boy had been a brilliant student. He was forced to leave school after the ninth grade in order to look for work. As yet he had found no steady job. He had been refused N.Y.A. assistance because he was considered unstable. The younger boy, crippled from poliomyelitis, was beginning to present similar problems. Also above average in intelligence, he had become a truant and was running around the streets. Mrs. Q. expressed a great deal of anxiety and discouragement. She felt completely inadequate for the situation. The boy had been forced to stay out of school last fall 
because he lacked clothes. Now he no longer wanted to attend. At the time of the visit, Mrs. Q. was working as a domestic for $\$ 6.00$ a week and her meals. The older son was out of the home, "scratching for himself." The younger was seldom at home, spending most of his time on the street. In addition to the strain of living on an inadequate income, Mrs. Q. felt strongly that her sons were wasting their abilities. Confused and unhappy, she faced a bleak future.

These two cases illustrate that failure to complete applications is not always indicative of a satisfactory adjustment by the family. We see in these cases many human strengths going to waste. Yet the agency service apparently was not desired. At any rate, the clients did not comply with what seened to be legitimate requirements and requests. The client must maintain responsibility for his own needs and for asking for help. Some clients seem to have less ability to comprehend their needs and the agency services. To what extent can the agency help them clarify the problem and yet not take over their right to selfdirection? The problem is worthy of further study. Nany of the eighteen clients visited expressed confusion and misunderstanding. As a result, some were resentful. Then the need was so great at the time of application, the families could hardly be expected to understand their rejection.

A few generalizations may be made about the standard of living of these families. It is clear from the case sumaries that most were living on a level far below health and decency. 
Although still in need in March, 19/4, almost all were in a more comfortable situation than they had been in November and December, 1940. Tables XLII and XLIII show that while seven families had incomes less than fifty per cent of the minimum standard budget at the time of rejection, none had that little in March.

\section{Table XIII}

November and December, 1940

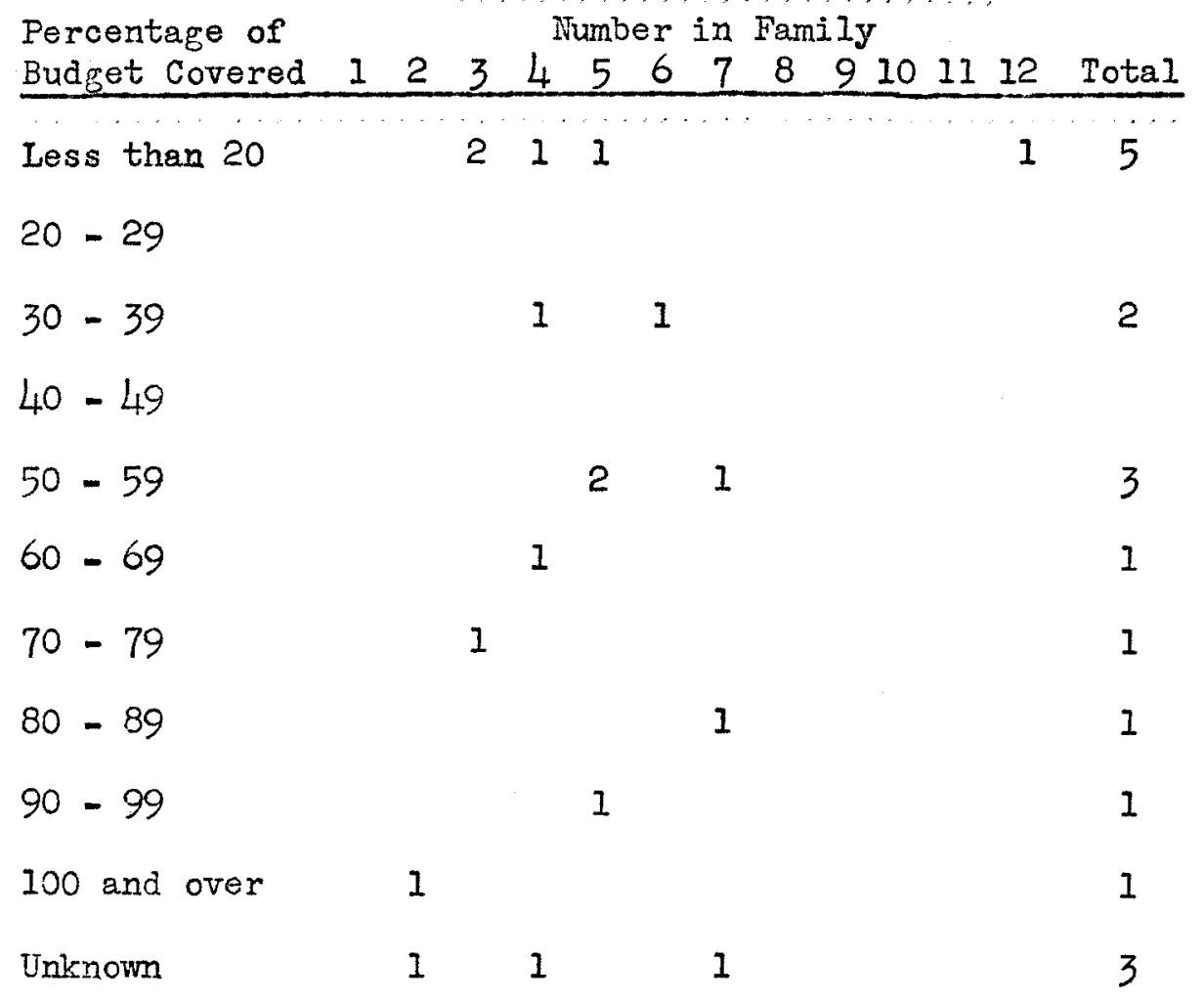

The facilities found in the homes bear witness to the fact that the housing of these families was neither decent nor sanitary. There was remarkably little change, however, from one period to the other. A large number of the families were definitely overorowded. The rentals were quite low on the whole. Although individual 
Table XIIII

March, 1941

Percentage of

Number in Family

$\begin{array}{llllllllllllll}\text { Budget Covered } & 1 & 2 & 3 & 4 & 5 & 6 & 7 & 8 & 9 & 10 & 11 & 12 & \text { Total }\end{array}$

Less than 20

$20-29$

$30-39$

$40-49$

$50-59$

13

4

$60-69$

1

1

2

$70=79$

1

1

2

$80-89$

111

$I$

4

$90-99$

1

1

100 and over

12

3

Unknown

11

2

families reported change, rentals for the group remained essentially the same. Figures on the amount of unpaid rent indicate the severity of the financial pressure felt by these families at the time of application. All debts showed a similar lessening in March.

\begin{tabular}{|c|c|c|}
\hline & $\begin{array}{l}\text { Nov. and } \\
\text { Dec. } 1940 \\
\end{array}$ & $\begin{array}{l}\text { March } \\
1941 \\
\end{array}$ \\
\hline Rent up to date & 5 & 10 \\
\hline In arrears less than one month & & 2 \\
\hline In arrears one to two months & 1 & 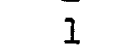 \\
\hline In arrears two to three months & 6 & 1 \\
\hline In arrears three to four months & 2 & 2 \\
\hline In arrears four months and more & 3 & $\bar{I}$ \\
\hline Unknown & 1 & 1 \\
\hline & $\frac{1}{18}$ & 18 \\
\hline
\end{tabular}


Table XIIV

\begin{tabular}{lcc} 
Facilities in Home & $\frac{\text { November and }}{\text { December, 1940 }}$ & Narch, 1941 \\
\cline { 2 - 3 } Running Water in Home & 14 & 14 \\
Inside Toilet & 8 & 8 \\
Outside Toilet & 8 & 8 \\
Inside Private Toilet & 6 & 6 \\
Private Bath & 4 & 4 \\
Gas & 10 & 11 \\
Electricity & 16 & 16 \\
Adequate Heating & & 10 \\
Arrangements & 10 &
\end{tabular}

Table XIV

Monthly Rent

Under $\$ 5.00$

$\$ 5.00-9.99$

$\$ 10.00-14.99$

$\$ 15.00-19.99$

$\$ 20.00-24.99$

$\$ 25.00$ and Over

Unknown

No Rent
November and December, 1940
5

8

1

2

1

1

1

1

18 
Table XIVI

Number of Rooms - March, 1941.

\begin{tabular}{ccccccc} 
Number in & \multicolumn{5}{c}{ Number of Rooms } \\
Family & 1 & 2 & 3 & 4 & 5 & Unknown \\
1 & & 1 & & & & \\
2 & & & & 2 & & \\
3 & 1 & & 1 & & & 1 \\
4 & & 1 & 2 & & & \\
5 & & 1 & 2 & 1 & 1 \\
6 & & & 1 & & \\
7 & & & & & & \\
8 & & & & & &
\end{tabular}


Although fourteen families reported having debts for both periods, eleven had managed to decrease their load by March.

Fourteen families reported having clothing adequate for work and school, while four families did not. An additional family had enough for work and school, but not for church. In Warch the figures were the same, except that in six families all of the members could not attend church.

Tabulation of the amount of money spent each week in March, 104l, for food shows that these families were not able to obtain the standard set by the minimum budget.

\section{March - Weekly Amount Spent for Food}

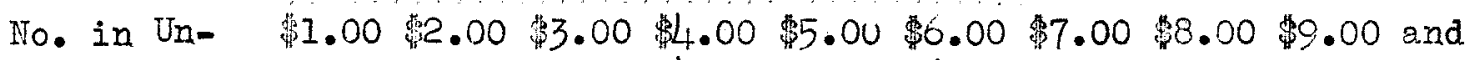
Family known $1.99 \quad 2.99 \quad 3.99 \quad 4.99 \quad 5.99 \quad 6.99 \quad 1.99 \quad 8.99$ over

$$
\begin{array}{ll}
1 & \\
2 & 1 \\
3 & \\
4 & 1 \\
5 & \\
6 & \\
7 & \\
8 &
\end{array}
$$$$
41
$$

1

1

$$
1
$$$$
1
$$$$
1
$$

1

$\begin{array}{ll} & 1 \\ 1 & 1\end{array}$

\begin{tabular}{|c|c|c|c|c|c|}
\hline & Meat & $\begin{array}{l}\text { Fresh } \\
\text { Milk } \\
\end{array}$ & $\begin{array}{l}\text { Canned } \\
M i l k \\
\end{array}$ & Fruit & $\begin{array}{c}\text { Green } \\
\text { Vegetables } \\
\end{array}$ \\
\hline Regularly & 5 & 4 & 1 & 5 & 11 \\
\hline Occasionally & 6 & 1 & 1 & 4 & 4 \\
\hline Seldom & 1 & & & 1 & \\
\hline Never & $\frac{4}{16}$ & $\frac{11}{16}$ & $\frac{14}{16}$ & $\frac{6}{16}$ & $\frac{1}{16}$ \\
\hline
\end{tabular}

1

1

Comparison of the various types of foods purchased again illustrates improved financial conditions in March. However, it is evident that 
Food Included in Diet of Eighteen Families - March

\begin{tabular}{|c|c|c|c|c|c|}
\hline & Meat & $\begin{array}{l}\text { Fresh } \\
\text { Milk } \\
\end{array}$ & $\begin{array}{c}\text { Canned } \\
\text { Mi Ik } \\
\end{array}$ & Fruit & $\begin{array}{c}\text { Green } \\
\text { Vegetables } \\
\end{array}$ \\
\hline $\begin{array}{l}\text { Regularly } \\
\text { Occasionally } \\
\text { Seldom }\end{array}$ & $\begin{array}{l}6 \\
8\end{array}$ & $\begin{array}{l}5 \\
1\end{array}$ & $\begin{array}{l}2 \\
1\end{array}$ & $\begin{array}{l}9 \\
5\end{array}$ & $\frac{12}{4}$ \\
\hline Never & $\frac{2}{16}$ & $\frac{10}{16}$ & $\frac{13}{16}$ & $\frac{2}{16}$ & $\overline{10 .}$ \\
\hline
\end{tabular}

even then there were serious lacks. Of the sixteen families for whom this information was obtained only five included fresh milk in the djet regularly, while two more used canned milk. Six femilies had meat or eggs. Nine used fruit and twelve had some green vegetables every day. That these families used these foods regularly did not mean they used them in adequate amounts.

This bleak picture has encouraging aspects, however. There seem to be noticeable effects of the broadened Intake poljcy. Whereas forty-four per cent of the families studied in larch, 19l,0, for whom information was known, had less than fifty per cent of the budget used, none of the present group did, although the standard was higher. It is impossible to compare the two studies accurately because of the differing numbers. However, it seems that the families in the present study had more adequate diets. Although ten of the one hundred families had been evicted in the three months following rejection, only one out of eighteen had had a similar experience the following year. Forty-five per cent of the other group was in arrears with rent three months after rejection. Twenty-nine per cent of the present group still had rent debt in Earch, 1941 . 
CONCLUSION 


\section{CONCLUSION}

The Municipal Bureau of Social Service was established ten years ago to deal with the problem of dependency. It was realized that, due to the widespread economic depression, private philanthropy could not cope adequately with the situation. In succeeding years, the function of the agency has undergone revolutionary changes. From giving work relief to unemployed, policy developed into giving general relief to those unable to work. The development of federal responsibility, first, under the Federal Emergency Relief Administration and, later, under the Works Frogram, was largely responsible for this change. That is, since the federal government had assumed some responsibility for the unemployed, Louisville, faced with inadequate funds, justified discontinuance of aid to this group. Except for emergency periods, there was no assistance to those able to work until November, 1940. Since that time acceptance or rejection has been based on need without reference to category.

The Municipal Bureau of Social Service operates as a division of the Department of Public Welfare. All employees of the agency are selected from the list of those passing the merit examinations. More adequate salaries and opportunity for advancement would offer incentive to the workers to improve their skills. The agenoy has been prevented from developing an adequate program by the lethargy of the people of Louisville. There have been many families in serious need, who have found themselves ineligible for any type of aid. Levels of relief have been so low as to endanger health and destroy morale. The citizens have not been sufficiently 
aware of the problem. We believe that they do not realize its extend and seriousness.

Although, since November, 1940, the intake policy of the agency has brodened, it is still restrictive. The budget used as a gauge of family need is not adequate for maintenance even on an emergency level. It represents only thirty to forty per cent of an acceptable minimum standard. The principle of fanily responsibility is carried to extreme lengths; cousins and even friends are asked to support families. Applicants for relief are forced to exhaust all possible resources. If they can manage by piling up debts, they are forced to do so. Landlords, grocers and other creditors bear a large part of the responsibility for supporting these families. From this study it seems that many human strengths are wasted. Compelled to administer a policy which they recognize as short-sighted the interviewers are faced with the difficult problem of selecting those who seem most in need, trying to utilize limited funds in the wisest manner.

The effects of the broadened Intake policy are apparent. The families studied three months after their rejection were making more satisfactory adjustments than the similar group studied the previous year. This seems to indicate also improved service on the part of the Interviewers. They were able, because of more liberal agency policy and because of slightly less pressure of time, to obtain better pictures of family situations and to make wiser decisions. More use was made of the services of other social agencies in the city. 
Among the families who were rejected there are only a few with members capable of earning adequate wages. Usually the only possible wage earners are aged, incapacitated or able to do only limited types of work. About fifty per cent of the families are dependent on women, many of whom could better use their time in caring for their children. The women, especially the domestics, are carrying responsibilities out of proportion to their skill and employment possibilities. The white women have practically no occupations. The colored women are domestics; even when employed they could not hope to adequately provide for their families. The low wages of domestics is a major community problem. The wage earners are poorly educated. They lack vocational training. Few have any definite work skills. As a group they represent the marginal workers, not many have ever been able to find steady employment.

During November and December, 1940, there were 277 families accepted for relief and 177 rejected. Those rejected were asked to depend on their owm resources, which we have found to be inadequate. They have managed through living with relatives, thus dragging down another family with them. Women have left children unsupervised while they work, coming home too exhausted to create a secure, affectionate home atmosphere. Family ties are strained by anxiety and insecurity. Children suffer from inadequate food. Economic pressure handicaps them in striving to attain education and training. Thwarted in attempts to achieve independence, they are disheartened and discouraged. 
A basic need in the agency is for more adequate funds. The relief grants of the agency are not adequate for maintenance. The restrictive intake policy excludes many needy persons. In the interest of preventing dependency, it would seem wise for the comunity to provide vocational training for children and adults. Many physically handicapped persons could become assets instead of liabilities if vocational re-training were made available.

It is not our purpose to propose methods for obtaining additional funds, but merely to point the need. At the time of writing, Hay, 1941, the program of national defense has temporarily, at least, reduced unemployment. The evidence, however, is that the problem of poverty is still in our midst. Although, to a large extent, the group changes from year to year, there is a continuing need. Because of their vocational handicaps, many families cannot hope to profit by increased industrial activity. This study emphasizes the need of an acceptable program of public assistance in Louisville. 
BIBLIOGRAPHY 


\section{BIBLIOGRAPHY}

\section{Pamphlots and Roports}

Blakey, Lois and Mc Neil, Ela ino Ogden. A Study of 100 Cases Whose Applications for Assistance Were Rejected by the Louisville Municipal Bureau of Social Service during the Months of November and December, 1932. Mimeographed, Louisville, May, 1940.

City of Louisville. Board of Education. Study of Relief Needs in Louisville Public Schools. Louisville, March 27, 1939.

City of Louisville, City Planning and Zoning Comission. Report on Emergency Work Relief Program in Louisville, Kentucky During the Period from November 23,1933 to March 16, 1936. Louisvillo. Typewritten, Narch 16, 1936.

City of Louisville. Department of Municipal Research and Service. A Study of the Municipal Bureau of Social Service Case Records on Direct Relief. Report No. 71, June 15, 1939. Prepared by B. D. Archer, Jr.

City of Louisville. Department of Municipal Research and Service. Public and Private Assistance in Louisville 1929-1938. Report No. 70. July 5, 1939. Prepared by Grant Hicks.

City of Louisville. Department of Public Welfare. Annual Reports.

City of Louisville. Municipal Bureau of Social Service. Annual Reports.

City of Louisville. Unemployment Relief Bureau. Annual Reports.

Hosch, Melville. Supporting Data to Budget Request for Mi.B.S.S. : September 1, 1939 through August 31, 1940. Forwarded to Direct or of Public Welfare, Director of Finance and President of the Board of Aldermen on June 14, 1949.

Hosch, Melville. Supplementary Data on M.B.S.S. Budgets for 19391940 Fisca 1 Year. Forwarded to Director of Public Welfare, Director of Finance and President of the Board of Aldermen on July 15, 1939.

League of Women Voters. Study of Relief Needs in the City of Lou is ville. Louisville, 1939. Typewritten. 
Lewis, Burdette and Kutak, Mrs. Robert. A Preliminary Plan for Securing a Better Coordination of the Governmental Forces of Loui sville and Jeffers on County. Mimeographed. Louisville, 1936. (prepared for a special committee appointed by Mayor Lililer and County Judge Benjamin Bwing.)

Loosley, R. 0., Director. Community Chests and Councils. The Louisville Survey and Summary Report. Louisville, Varch, 1939.

Mallon, John H., Tachau, Charles G., and Dennis, Force, Report of the Mayor's Committee to Consider the Relief Situation in Louisville. Typewritten. Louisville, February 6,1939.

Russell, Solon. Evaluation of the Report of the Mayor's Committee on Relief. Typewritten. Louisville, 1939.

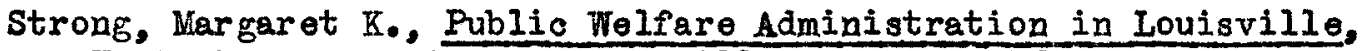
Kentucky. Typewritten. Louisville, March, 1935.

Works Projects Administration in Kentucky. Intake and Certification Manua I. Mimeograp hed, October, 1940.

United Statea. Department of Labor. United States Children's Bureau. The Community Welfare Picture. Washington. June, 1939.

United States. Social Security Board. Annua Reports.

Newspepers and Periodicals

Courier Journal. Louisville, Kentucky.

Louisville Times. Louisville, Kentucky.

United States. Social Security Board. Social Seourity Bulletin. 
APPENDIX 
Figures Used in Computing Minimum Standard Budgets on Rejected Families.

Number in Family Rent Fer Nonth Gas and Lights Household Supplies

$\begin{array}{rrrr}1 & \$ 5.00 & \$ 1.55 & \$ 0.80 \\ 2 & 6.40 & 2.10 & 1.35 \\ 3 & 9.80 & 2.70 & 1.90 \\ 4 & 13.20 & 3.45 & 2.20 \\ 5 & 16.60 & 4.20 & 3.00 \\ 6 & 20.00 & 4.80 & 3.30 \\ 7 & 23.40 & 5.40 & 4.35 \\ 8 & 25.00 & 6.00 & 4.65 \\ 9 & 25.00 & 6.60 & 5.70 \\ 10 & 25.00 & 7.20 & 6.00\end{array}$

Food Cost Per Month

Child 6 months to 2 years $\$ 5.15$ 3-5 years 6.01 6-8 years $\quad 7.83$

9-11 years $\quad 8.61$

$12-16$ years $\quad 9.20$

Woman and light work man 6.55 Whan

8.75

For families of six to eight persons, deduct ten per cent of food costs; for families of eight and above, deduct twenty per cent. For one person households, increase thirty per cent.

\section{Clothing Cost Per Month}

$\begin{array}{ll}\text { Infant } & .95 \\ \text { Girl 1-4 } & 1.59 \\ \text { Boy 1-4 } & 1.20 \\ \text { Girl 5-9 } & 2.26 \\ \text { Boy } 5-9 & 1.94 \\ \text { Girl 10-12 } & 2.57 \\ \text { Boy 10-16 } & 3.18 \\ \text { Girl 12-16 } & 3.09 \\ \text { Working girl } & 5.95 \\ \text { Working Woman } & 4.70 \\ \text { Housewife } & 2.87 \\ \text { Aged woman, inactive } & 2.52 \\ \text { Active man } & 4.81 \\ \text { Aged man, inactive } & 2.61\end{array}$

Health: Twenty cents per month per person.

Insurance: Five cents a week for children, fjifteen cents a week for adults; maximum of twenty-five cents a week for any one family.

Coal: One half ton a month (2.85) for one or two persons; one ton per month (\$5.05) for three or more persons in family. 


\section{Form A.}

Status Race Mar. Status Source of Referral Appl. for No.

Came to Louisville

Date

1.

Age Sex Wage Occupation Edu. or Grade Health Employ. Status

2.

3.

5.

6.

7.

Others in Household Age Sex Wage Occupation Health

8.

9.

10.

11.

SSEX

Family income
Relatives income
Total
Min. Budget
Difference

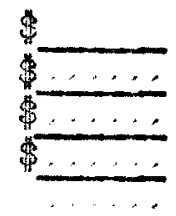

Reason for Refusal

Length of Unemployment 
QUESTIONNAIRE USED AS GUIDE IN MAKING HOME VISITS

Number

Date of visit

Family composition

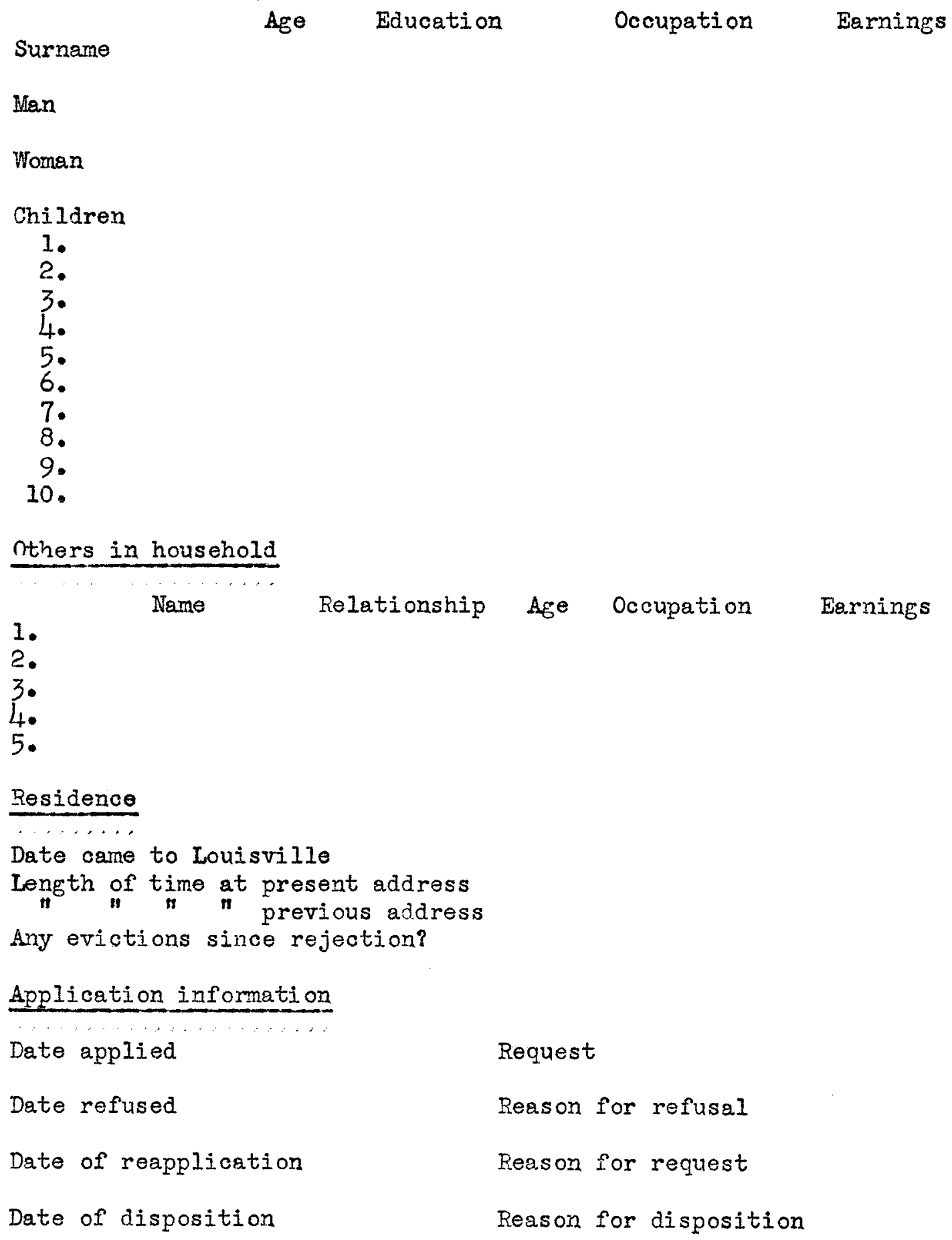


Income

Amount

Help in kind

Wages

Other sources

Means

Regular employment

Part time employment

Odd jobs

Savings

Sale of property

Unempl oyment Compensation

Old legal claims

Pensions

Relatives

Friends

Churches

Social Agencies

Merchants and landlords

Other

Minimum Standard Budget
November or

Decomber, 1940

March, 1941 
Changes in housing standards

Rental

Amount

Up to date?

Months in arrears

Number of evictions

Number of rooms

Utilities

Gas

Lights

Substitute

Water in home

Heating adequate?

Bathroom?

Toilet?

Does or did client have

His own furniture?

indebtedness

payment up to date?

Sufficient number of chairs?

Sufficient number of dishes?

Surficient bedding?

Number of persons per bed. 
Changes in general living standards

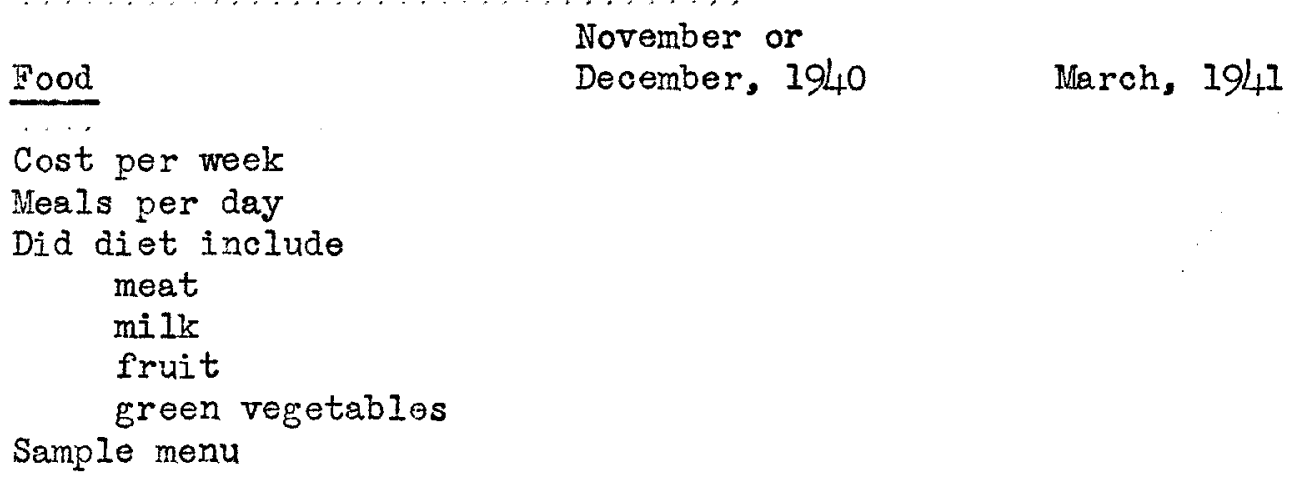

Clothing

Adequate for

work

school

church

Household supplies

cost per week

Recreation

kind.

$\cos t$

Insurance

number of policies

type of policies

cost per week

changes in insurance since rejection

Debts (list) 
Health

Member of household

Man

Woman

Children
November or

December, 1940

March, 1941

Reas on for lack of medical care

Deatins

Have deaths occurred since the discontinuance of regular income?

Does family consider financial stress a contributing factor?

How was burial provided?

School attendance

Estimate of the effect of financial condition on school attendance of children. 